\title{
Post-Translational Protein Deimination Signatures in Plasma and Plasma EVs of Reindeer (Rangifer tarandus)
}

\author{
Stefania D’Alessio ${ }^{1}$, Stefanía Thorgeirsdóttir ${ }^{2}$, Igor Kraev ${ }^{3} \mathbb{D}$, Karl Skírnisson ${ }^{2}$ and Sigrun Lange ${ }^{1, * \mathbb{D}}$ \\ 1 Tissue Architecture and Regeneration Research Group, School of Life Sciences, University of Westminster, \\ London W1W 6UW, UK; w1650366@my.westminster.ac.uk \\ 2 Institute for Experimental Pathology at Keldur, University of Iceland, Keldnavegur 3, 112 Reykjavik, Iceland; \\ stef@hi.is (S.T.); karlsk@hi.is (K.S.) \\ 3 Electron Microscopy Suite, Faculty of Science, Technology, Engineering and Mathematics, Open University, \\ Milton Keynes MK7 6AA, UK; igor.kraev@open.ac.uk \\ * Correspondence: S.Lange@westminster.ac.uk; Tel.: +44-(0)207-911-5000 (ext. 64832)
}

check for

updates

Citation: D'Alessio, S.;

Thorgeirsdóttir, S.; Kraev, I.;

Skírnisson, K.; Lange, S.

Post-Translational Protein

Deimination Signatures in Plasma and Plasma EVs of Reindeer

(Rangifer tarandus). Biology 2021, 10,

222. https://doi.org/10.3390/

biology10030222

Academic Editor: Ansgar Poetsch

Received: 10 February 2021

Accepted: 11 March 2021

Published: 13 March 2021

Publisher's Note: MDPI stays neutral with regard to jurisdictional claims in published maps and institutional affiliations.

Copyright: (c) 2021 by the authors. Licensee MDPI, Basel, Switzerland. This article is an open access article distributed under the terms and conditions of the Creative Commons Attribution (CC BY) license (https:/ / creativecommons.org/licenses/by/ $4.0 /)$.
Simple Summary: Reindeer are an important wild and domesticated species of the Arctic, Northern Europe, Siberia and North America. As reindeer have developed various strategies to adapt to extreme environments, this makes them an interesting species for studies into diversity of immune and metabolic functions in the animal kingdom. Importantly, while reindeer carry natural infections caused by viruses (including coronaviruses), bacteria and parasites, they can also act as carriers for transmitting such diseases to other animals and humans, so called zoonosis. Reindeer are also affected by chronic wasting disease, a neuronal disease caused by prions, similar to scrapie in sheep, mad cows disease in cattle and Creutzfeldt-Jakob disease in humans. The current study assessed a specific protein modification called deimination/citrullination, which can change how proteins function and allow them to take on different roles in health and disease processes. Profiling of deiminated proteins in reindeer showed that many important pathways for immune defenses, prion diseases and metabolism are enriched in deiminated proteins, both in plasma, as well as in plasma extracellular vesicles. This study provides a platform for the development of novel biomarkers to assess wild life health status and factors relating to zoonotic disease.

Abstract: The reindeer (caribou) Rangifer tarandus is a Cervidae in the order Artiodactyla. Reindeer are sedentary and migratory populations with circumpolar distribution in the Arctic, Northern Europe, Siberia and North America. Reindeer are an important wild and domesticated species, and have developed various adaptive strategies to extreme environments. Importantly, deer have also been identified to be putative zoonotic carriers, including for parasites, prions and coronavirus. Therefore, novel insights into immune-related markers are of considerable interest. Peptidylarginine deiminases (PADs) are a phylogenetically conserved enzyme family which causes post-translational protein deimination by converting arginine into citrulline in target proteins. This affects protein function in health and disease. Extracellular vesicles (EVs) participate in cellular communication, in physiological and pathological processes, via transfer of cargo material, and their release is partly regulated by PADs. This study assessed deiminated protein and EV profile signatures in plasma from sixteen healthy wild female reindeer, collected in Iceland during screening for parasites and chronic wasting disease. Reindeer plasma EV profiles showed a poly-dispersed distribution from 30 to $400 \mathrm{~nm}$ and were positive for phylogenetically conserved EV-specific markers. Deiminated proteins were isolated from whole plasma and plasma EVs, identified by proteomic analysis and protein interaction networks assessed by KEGG and GO analysis. This revealed a large number of deimination-enriched pathways for immunity and metabolism, with some differences between whole plasma and EVs. While shared KEGG pathways for whole plasma and plasma EVs included complement and coagulation pathways, KEGG pathways specific for EVs were for protein digestion and absorption, platelet activation, amoebiasis, the AGE-RAGE signaling pathway in diabetic complications, ECM receptor interaction, the relaxin signaling pathway and the estrogen signaling pathway. KEGG pathways specific for whole plasma were pertussis, ferroptosis, SLE, thyroid hormone synthesis, phagosome, Staphylococcus aureus infection, vitamin digestion and absorption, 
and prion disease. Further differences were also found between molecular function and biological processes GO pathways when comparing functional STRING networks for deiminated proteins in EVs, compared with deiminated proteins in whole plasma. This study highlights deiminated proteins and EVs as candidate biomarkers for reindeer health and may provide information on regulation of immune pathways in physiological and pathological processes, including neurodegenerative (prion) disease and zoonosis.

Keywords: protein deimination/citrullination; peptidylarginine deiminase (PAD); extracellular vesicles (EVs); reindeer (Rangifer tarandus); immunity; metabolism; gene regulation; prion disease; zoonosis

\section{Introduction}

The reindeer (Rangifer tarandus), also known as the caribou in North America, is a mammal of the order Artiodactyla, family Cervidae, and has a circumpolar distribution. Reindeer play an important role in economy, society, culture and ecological values among populations of Eurasia and were fundamental for the colonization of the northern part of Eurasia. They have been a source of food among indigenous culture and were sporadically used for transportation, and therefore can be considered as a semi-domesticated species [1]. Reindeer are adapted to extreme environments throughout their evolution, exhibiting distinctive and unique biological characteristics relating to fat metabolism processes, changes to their internal biological clock, limited heat loss and low resting metabolic rate. However, the underlying molecular and genetic basis for these traits remains largely unknown $[1,2]$. The IUCN Red List of Threatened Species (2016) has classified reindeer as a vulnerable species due to a decline of individuals, possibly attributed to habitat shift and/or their susceptibility to chronic wasting disease (CWD), a fatal neurodegenerative disorder $[3,4]$. Importantly also, $R$. tarandus may play roles in various zoonotic diseases, including parasitic, bacterial and viral ones [5-8], and deer have furthermore been recently identified to be new reservoir hosts for SARS-CoV-2 [9].

While the reindeer genome has been sequenced [10], and genetic diversity and mitochondrial DNA have furthermore been studied [11], no studies have hitherto been performed into mechanisms relating to post-translational modifications such as deimination, which is caused by peptidylarginine deiminases (PADs). Furthermore, while research on extracellular vesicles (EVs) is a major field in relation to biomarker discovery in human pathologies, and recent comparatives studies have highlighted their value in a range of wild, domestic and commercially valuable land and aquatic animals throughout the phylogeny tree [12-25], the field is still in its infancy in relation to studies and biomarker development in wild animals.

Peptidylarginine deiminases (PADs) are a phylogenetically conserved calcium-dependent family of enzymes. PADs convert arginine into citrulline in an irreversible manner, leading to post-translational modification (citrullination/deimination) in numerous target proteins of cytoplasmic, nuclear and mitochondrial origin [17,26-30]. Deimination causes structural protein changes which can affect protein function and consequently downstream protein-protein interactions. Deimination can, among other, contribute to neo-epitope generation, which results in inflammatory responses, as well as affect gene regulation and neutrophil extracellular trap formation (NETosis) via deimination of histones [31-35]. As post-translational changes contribute to protein moonlighting, which allows one protein to exhibit different functions within one polypeptide chain [36], deimination may facilitate such functional diversity of proteins in health and disease.

In mammals, five PAD isozymes are known, while lower in the phylogeny tree, there is less diversification of PADs, with three PAD isozymes described in birds and reptiles, but only one PAD form in fish $[17,18,26,28,29,37]$. Furthermore, PAD homologues, also referred to as arginine deiminases (ADI) [38] have been described in parasites [39], bacteria [40,41] 
and fungi [42]. This places PADs as important proteins both in host immune defenses, as well as in host-pathogen interactions.

A majority of studies on PADs and downstream deimination have related to human pathological mechanisms, but recently a comparative body of research has focused on identifying putative roles for PADs in physiological and immunological pathways in a wide range of taxa throughout the phylogenetic tree, including land and sea mammals, reptiles, birds, bony and cartilaginous fish, Mollusca and Crustacea [16-25,28,29]. PADs have furthermore been identified to have roles in mucosal, innate and adaptive immunity in a range of taxa $[17-20,25,28,29,43,44]$. Importantly, PADs have also been identified as important players in infection and anti-pathogenic responses, including anti-viral $[45,46]$ and anti-parasitic ones [39], as well as in anti-bacterial mechanisms [40,41]. Furthermore, as roles for PADs in EV release and deiminated protein cargo in EVs in health and disease, in diverse taxa and comparative animal models of disease, are gaining increased attention, investigations into reindeer may be of some interest.

EV biogenesis and regulation of EV release from cells has been shown to be regulated by PADs to some extent, and as this has been identified in a range of taxa, it appears to be a phylogenetically conserved function $[39,41,47-50]$. EVs participate in cellular communication and can be isolated from many body fluids, including serum, plasma, saliva and urine. EVs play physiological and pathological roles via transfer of cargo proteins and genetic material, including in inflammatory responses, in infection and hostpathogen interactions [34,39,51-55]. As EVs carry information from their cells of origin, their cargo signatures are usable biomarkers [56,57]. Currently, as relatively few studies on EVs have been conducted in wild animals $[14,15,25]$ this is a pioneering and promising field for novel biomarker discovery and development.

As, to date, neither PADs and associated deimination nor EVs have been assessed in reindeer, the current study aimed at profiling protein deimination in plasma and plasma EVs for assessment of regulation on protein networks and identification of putative biomarkers to gain new insights into both immune system and metabolic adaptations of reindeer. This study may further current understanding of the roles for post-translational modifications in functional diversification of conserved proteins throughout phylogeny.

\section{Materials and Methods}

\subsection{Plasma Sampling}

Blood samples were taken from sixteen individual female reindeer ( $R$. tarandus)—average age approximately 7 years (range 1.5-12 years old)—sampled in Iceland. The sampling was part of research dealing with general health of Icelandic reindeer with specific emphasis on chronic wasting disease (CWD) and presence of parasites. Sample collection was in accordance with Icelandic laws and regulations on sampling from wild animals (64/1994) and licenses of the Institute for Experimental Pathology at Keldur, University of Iceland (number \#0001 kt-650269 - 4549), approved by the central animal ethics committee in Iceland (Icelandic Food Regulation Authority, MAST Matvælastofnun). The plasma was isolated according to standard procedures from EDTA blood samples. Brain samples from the same animals were screened for presence of prion disease by ELISA (TeSeE ${ }^{\circledR}$, Bio-Rad, UK) following standard procedures at the Institute for Experimental Pathology at Keldur, and the animals were confirmed to be disease free and healthy. Plasma was aliquoted at $250 \mu \mathrm{L}$ and stored at $-80{ }^{\circ} \mathrm{C}$ until further use for the individual experiments.

\subsection{Isolation of Extracellular Vesicles and Nanoparticle Tracking Analysis (NTA)}

Reindeer plasma EVs were prepared from the individual plasma (thawed on ice) of the sixteen animals using sequential centrifugation and ultracentrifugation. Procedures were carried out according to our previously standardized and described protocols $[18,23,43]$, also following recommendations of MISEV2018 (the minimal information for studies of extracellular vesicles 2018) [58]. For each individual plasma EV preparation, $100 \mu \mathrm{L}$ of reindeer plasma was diluted 1:5 in Dulbecco's PBS (DPBS, ultrafiltered using a $0.22 \mu \mathrm{m}$ 
filter, before use). This was then centrifuged for $20 \mathrm{~min}$ at $4000 \times g$ at $4{ }^{\circ} \mathrm{C}$, to remove apoptotic bodies and aggregates. Supernatants were then collected and ultra-centrifuged at $100,000 \times g$ at $4{ }^{\circ} \mathrm{C}$ for $1 \mathrm{~h}$. This resulted in EV-enriched pellets, which were resuspended each in $500 \mu \mathrm{L}$ DPBS and thereafter ultra-centrifuged again for $1 \mathrm{~h}$ at $100,000 \times g$, at $4{ }^{\circ} \mathrm{C}$. The final resulting EV pellets were resuspended each in $100 \mu \mathrm{L}$ of DPBS. The EVs were kept frozen at $-80{ }^{\circ} \mathrm{C}$ until used in the procedures described below (all assessments were performed with EV preparations that had not been frozen for longer than 1 week). Plasma EV size distribution profiles were generated and EVs were quantified using nanoparticle tracking analysis (NTA), based on Brownian motion of particles in suspension, and carried out using the NanoSight NS300 system (Malvern Panalytical Ltd., Malvern, UK). Prior to application on the NanoSight, the EV samples were diluted 1/100 in DPBS (10 $\mu \mathrm{L}$ of EV preparation diluted in $990 \mu \mathrm{L}$ of DPBS). The diluted EV samples were applied to the NanoSight NS300 (Malvern Panalytical, UK), recording four repetitive reads, 60 sec each. Particle numbers per frame were 40 to 60 , camera settings were at level 12 for recording and for post-analysis the threshold was set at 3. Replicate histograms were generated from these videos using the NanoSight software 3.0 (Malvern), representing mean and confidence intervals of the four recordings for each sample.

\subsection{Transmission Electron Microscopy (TEM)}

Plasma EVs were assessed for morphology using TEM, using a pool of plasma EVs from five animals. The procedure was similar as previously described [16,20]. Following thawing of isolated EV pellets (stored frozen for 1 week before imaging), the EVs were resuspended in $100 \mathrm{mM}$ sodium cacodylate buffer $(\mathrm{pH} 7.4)$. One drop $(\sim 3-5 \mu \mathrm{L})$ of the EV suspension was placed onto a grid which held a carbon support film which had been previously glow-discharged. Following partial drying of the EV suspension, the sample was fixed for $1 \mathrm{~min}$ at room temperature by placing the grid onto a drop of a fixative solution (2.5\% glutaraldehyde in $100 \mathrm{mM}$ sodium cacodylate buffer $(\mathrm{pH} 7.0)$ ). The grid was applied to the surface of three drops of distilled water for washing of the EV sample, removing excess water using a filter paper. The EVs were then stained for 1 min with $2 \%$ aqueous Uranyl Acetate (Sigma-Aldrich), removing excess stain with a filter paper and air drying the grid. TEM imaging of EVs was carried out with a JEOL JEM 1400 transmission electron microscope (JEOL, Tokyo, Japan), which was operated at $80 \mathrm{kV}$, using a magnification of $30,000 \times$ to $60,000 \times$. Recording of digital images was performed with an AMT XR60 CCD camera (Deben, UK).

\subsection{Isolation of Deiminated Proteins Using F95 Enrichment}

Total deiminated proteins were isolated from reindeer plasma and plasma EVs using the F95 pan-deimination antibody (MABN328, Merck, UK) and the Catch and Release ${ }^{\circledR}$ v2.0 immunoprecipitation kit (Merck), according to previously described methods in a range of taxa $[16,18,20,23,43]$. The F95-antibody specifically detects proteins modified by citrullination and has been developed against a deca-citrullinated peptide [59]. Pools of plasma from five individual animals $(5 \times 20 \mu \mathrm{L})$ and, correspondingly, EV isolates from the same five individual animals ( $5 \times 20 \mu \mathrm{L} \mathrm{EVs}$ ) were used for F95 enrichment, which was performed at $4{ }^{\circ} \mathrm{C}$ overnight, using a rotating platform. Elution of deiminated (F95-bound) proteins from the columns was performed with the elution buffer provided with the immunoprecipitation kit and according to the manufacturer's instructions (Merck), and the protein eluate was thereafter diluted 1:1 in 2× Laemmli sample buffer (BioRad, Watford, UK). Samples were kept frozen at $-20{ }^{\circ} \mathrm{C}$ until further use for SDS-PAGE analysis, Western blotting and in-gel digestion for LC-MS/MS analysis, as described below.

\subsection{Western Blotting Analysis}

For Western blotting, SDS-PAGE was carried out on plasma, as well as plasma EV samples. All samples were diluted 1:1 in denaturing $2 \times$ Laemmli sample buffer (containing $5 \%$ beta-mercaptoethanol, BioRad, UK) and heated for $5 \mathrm{~min}$ at $100{ }^{\circ} \mathrm{C}$. Protein separation 
was carried out using 4-20\% gradient TGX gels (BioRad UK), followed by Western blotting at $165 \mathrm{~V}$ for $1 \mathrm{~h}$ on a Trans-Blot ${ }^{\circledR}$ SD semi-dry transfer cell (BioRad, UK). Membranes were stained with PonceauS (Sigma, UK) to assess even protein transfer and then blocked with $5 \%$ bovine serum albumin (BSA, Sigma, UK) in Tris-buffered saline (TBS) containing $0.1 \%$ Tween20 (BioRad, UK; TBS-T) for $1 \mathrm{~h}$ at room temperature. Primary antibody incubation was carried out overnight at $4{ }^{\circ} \mathrm{C}$ on a shaking platform using the following antibodies for reindeer plasma: F95 pan-deimination antibody (MABN328, Merck; diluted 1/1000 in TBS-T) and anti-human PAD2 (ab50257, Abcam, diluted 1/1000 in TBS-T), PAD3 (ab50246, diluted 1/1000 in TBS-T) and PAD4 (ab50332, diluted 1/1000 in TBS-T) antibodies, for detection of putative PAD protein homologues. PAD2 is considered the most conserved PAD isozyme and the anti-human PAD2 antibody was previously shown to cross-react with PADs across taxa [17-25,28,29,60,61], while both the PAD3 and PAD4 antibodies have also been found to cross react with other species, including bird, reptile and bovine $[18,20,60]$. EV-cargo was also assessed for PAD2, PAD3 and PAD4 as well as deiminated proteins (F95). For characterization of reindeer plasma EVs, the EV-markers CD63 (ab216130, Abcam, UK) and Flotillin-1 (ab41927); diluted 1/1000 in TBS-T) were used, and both have previously been shown to cross-react with EVs from other taxa, besides human. Following primary antibody incubation overnight at $4{ }^{\circ} \mathrm{C}$, the nitrocellulose membranes were washed at RT in TBS-T for $3 \times 10 \mathrm{~min}$ and thereafter incubated with HRP-conjugated secondary antibodies (anti-rabbit IgG, BioRad; or anti-mouse IgM, BioRad, respectively, diluted 1/3000 in TBS-T), for $1 \mathrm{~h}$ at RT. The membranes were then washed for $4 \times 10 \mathrm{~min}$ TBS-T, followed by one wash in TBS without Tween 20 and digitally visualized, using enhanced chemiluminescence (ECL, Amersham, UK) in conjunction with the UVP BioDoc-ITTM System (Thermo Fisher Scientific, Dartford, UK).

\subsection{Silver Staining}

SDS-PAGE (using 4-20\% gradient TGX gels, BioRad, UK) was carried out under reducing conditions for the F95-enriched protein eluates from both whole plasma and plasma EVs. The gels were then silver stained using the BioRad Silver Stain Plus Kit (1610449, BioRad, UK), according to the manufacturer's instructions.

\subsection{Liquid Chromatography with Tandem Mass Spectrometry (LC-MS/MS) Analysis of Deiminated Protein Candidates}

Liquid chromatography with tandem mass spectrometry (LC-MS/MS) was carried out to identify deiminated proteins from reindeer plasma and plasma EVs (pool of $n=5$ deer for plasma as well as plasma EVs, using the isolates from the same animals), according to previously described methods in other taxa $[17,19,20]$. Before LC-MS/MS analysis, the F95-enriched protein preparations (diluted 1:1 in 2x Laemmli buffer and boiled for $5 \mathrm{~min}$ at $100{ }^{\circ} \mathrm{C}$ ) were run $0.5 \mathrm{~cm}$ into a $12 \%$ TGX gel (BioRad, UK). The concentrated protein band (containing the F95 eluate) was excized, trypsin digested and subjected to proteomic analysis using a Dionex Ultimate 3000 RSLC nanoUPLC (Thermo Fisher Scientific Inc., Waltham, MA, USA) system in conjunction with a QExactive Orbitrap mass spectrometer (Thermo Fisher Scientific Inc, Waltham, MA, USA). Peptide separation was performed using reverse-phase chromatography (flow rate $300 \mathrm{~nL} / \mathrm{min}$ ) and a Thermo Scientific reversephase nano Easy-spray column (Thermo Scientific PepMap C18, $2 \mu \mathrm{m}$ particle size, $100 \mathrm{~A}$ pore size, $75 \mu \mathrm{m}$ i.d. $\times 50 \mathrm{~cm}$ length). Peptides were loaded onto a pre-column (Thermo Scientific PepMap 100 C18, $5 \mu \mathrm{m}$ particle size, 100 A pore size, $300 \mu \mathrm{m}$ i.d. $\times 5 \mathrm{~mm}$ length) from the Ultimate 3000 autosampler $(0.1 \%$ formic acid for $3 \mathrm{~min}$, flow rate $10 \mu \mathrm{L} / \mathrm{min}$ ). Thereafter, peptides were eluted from the pre-column onto the analytical column. The linear gradient employed was $2-40 \%$ solvent B ( $80 \%$ acetonitrile, $20 \%$ water $+0.1 \%$ formic acid) for $30 \mathrm{~min}$. An Easy-Spray source (Thermo Fisher Scientific Inc.) was used to spray the LC eluant into the mass spectrometer. An Orbitrap mass analyzer (set at a resolution of 70,000 ) was used to measure all $\mathrm{m} / \mathrm{z}$ values of eluting ions, scanned between $\mathrm{m} / \mathrm{z} 380$ and 1500. Fragment ions were automatically isolated and generated using data-dependent scans (Top 20) by higher-energy collisional dissociation (HCD, NCE: 25\%) in the HCD 
collision cell. The resulting fragment ions were measured using the Orbitrap analyzer set at a resolution of 17,500. Singly charged ions and ions with unassigned charge states were excluded from selection for MS/MS, employing a dynamic exclusion window of $20 \mathrm{~s}$. The data were processed post-run, using Protein Discoverer (version 2.1., Thermo Scientific). All MS/MS data were converted to mgf files. The files were submitted to the Mascot search algorithm (Matrix Science, London, UK) to identify deiminated protein hits. Search was conducted against a common UniProt database against Artiodactyla ( $\mathrm{CCP}_{-}$Artiodactyla Artiodactyla_20201013; 840,112 sequences; 473,198,619 residues). An additional search was conducted against a common contaminant database (cRAP 20190401; 125 sequences; 41,129 residues). The fragment and peptide mass tolerances were set to $0.1 \mathrm{Da}$ and $20 \mathrm{ppm}$, respectively. The significance threshold value was set at of $p<0.05$ and a peptide cut-off score of 46 for the common Artiodactyla database (carried out by Cambridge Proteomics, Cambridge, UK).

\subsection{Protein-Protein Interaction Network Analysis}

To predict and identify putative protein-protein interaction networks associated with the deiminated proteins from reindeer plasma and plasma EVs, STRING analysis (Search Tool for the Retrieval of Interacting Genes/Proteins; https://string-db.org/) was performed. Protein networks were generated based on protein names and applying the function of "search multiple proteins" in STRING (https://string-db.org/) using the Artiodactyla protein database. For a representative choice of a Artidoactyla protein database, Bos taurus was selected, as no species-specific Rangifer tarandus protein database is available in STRING, and within Artiodactyla the highest protein hit match was found with Bos taurus. Parameters applied in STRING were "basic settings" and "medium confidence". Nodes are connected with color lines which represent the following evidence-based interactions for the network edges: "known interactions" (these are based on experimentally determined curated databases), "predicted interactions" (these are based on gene neighborhood, gene co-occurrence, gene fusion, via text mining, protein homology or co-expression). Gene ontology (GO) and KEGG (Kyoto Encyclopedia of Genes and Genomes) pathways for the deiminated protein networks were furthermore assessed in STRING and are highlighted by color coding (for each network analysis figure, please see the corresponding color code key included for the individual nodes and connective lines).

\subsection{Neighbor-Joining Tree Construction for PADs from Deer}

To reconstruct a phylogeny tree for Artiodactyla PADs, protein sequences of known and previously reported PAD isozymes from several deer were compared with other mammals. No PAD protein sequences have been reported for reindeer in open protein databases. For reconstruction of a neighbor joining tree, PAD sequences were therefore used from white-tailed deer (Odocoileus virginianus texanus), red deer (Cervus elaphus hippelaphus) and cow (Bos taurus) and compared with human PADs. The following sequences were used for the neighbor joining tree construction (using Clustal Omega https: / www. ebi.ac.uk/Tools/msa/clustalo/): Odocoileus virginianus texanus PAD1 (XP_020733655.1), PAD2 (XP_020733656.1), PAD3 (XP_020733658.1), PAD4 (XP_020754850.1) and PAD6 (XP_020754849.1) isozymes; Bos taurus PAD1 (NP_001094742.1), PAD2 (NP_001098922.1), PAD3 (XP_010800991.1), PAD4 (NP_001179102.1), and PAD6 (XP_002685843.1) isozymes; Cervus elaphus hippelaphus PAD1 (OWK12974.1), PAD4 (OWK12644.1) isozymes, human (Homo sapiens) PAD1 (NP_037490.2), PAD2 (NP_031391.2), PAD3 (NP_057317.2), PAD4 (NP_036519.2) and PAD6 (NP_997304.3). A neighbor-joining phylogeny tree was constructed following sequence alignment, and homology of deer PADs between human and deer was determined by percent identity matrix, using Clustal Omega (https://www.ebi. ac.uk/Tools/msa/clustalo/). 


\subsection{Statistical Analysis}

Generation of NTA curves was carried out using the Nanosight 3.0 software (Malvern, UK). The NTA curves show mean (black line) and standard error of mean (SEM), and the confidence intervals are indicated (red line). Protein-protein interaction networks were generating using STRING (https://string-db.org/), applying basic settings and medium confidence. Significance was considered as $p \leq 0.05$.

\section{Results}

\subsection{Characterization of Reindeer Plasma EVs}

The NanoSight NS300 was utilized for NTA assessment of particle numbers and size distribution of reindeer plasma EVs. These were found to be poly-dispersed in the size range of $40-500 \mathrm{~nm}$, with the majority of the EVs in the size range of 100-250 nm (Figure 1A). Transmission electron microscopy (TEM) confirmed EV morphology (Figure 1B) and Western blotting confirmed positive signal with two phylogenetically conserved EV-specific markers, CD63 and Flot-1 (Figure 1C). EV yield from plasma of the different individuals showed some variability within the range of $4.72 \times 10^{9}-3.11 \times 10^{10}$ particles $/ \mathrm{mL}$ (Figure 1D) and modal EV size was in the range of 110-156 nm (Figure 1E).

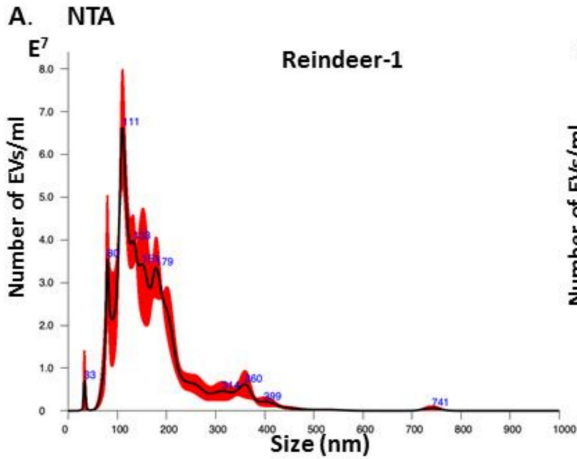

B. TEM

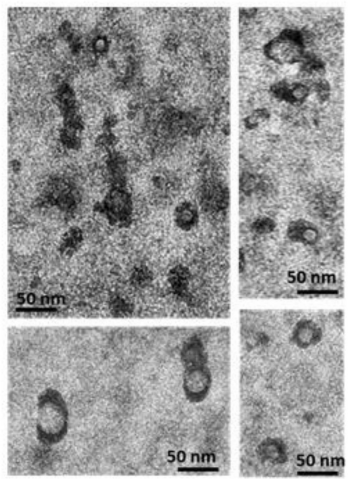

WB

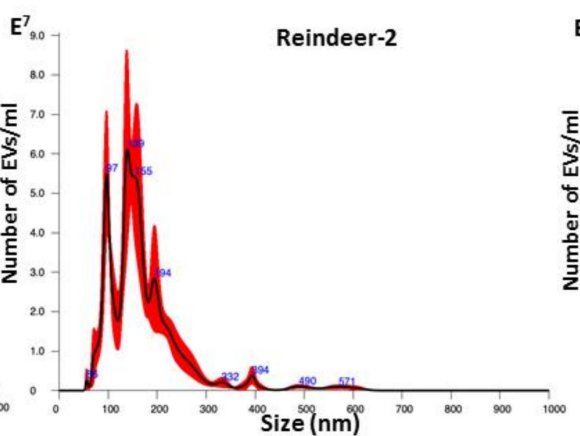

D.

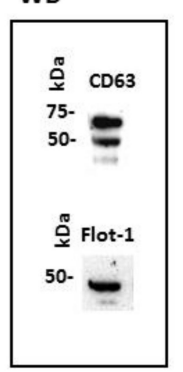

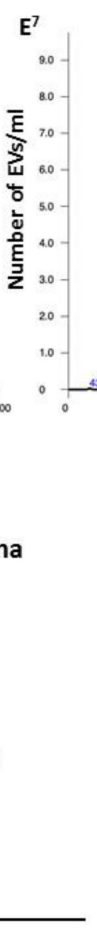

Reindeer-3

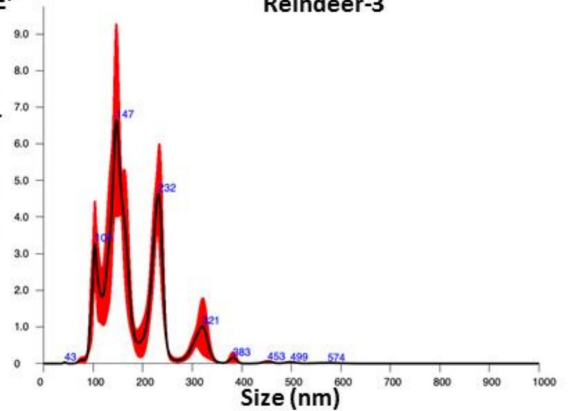

E.

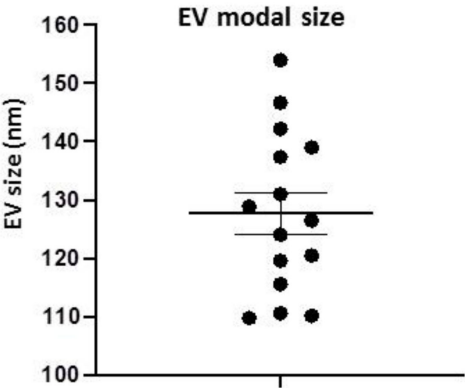

Figure 1. Plasma EV profiling of Rangifer tarandus. (A) Nanoparticle tracking analysis (NTA) showing a poly-dispersed distribution of reindeer plasma EVs in the size range of 30-400 nm, from three representative animals, showing some individual variation. (B) Transmission electron microscopy (TEM) analysis of EVs derived from reindeer's plasma; the scale bar in all images represents $50 \mathrm{~nm}$. (C) Western blotting analysis (WB) showing reindeer plasma EVs positive for CD63 and Flot-1; the molecular weight standard is indicated in kilodaltons (kDa). (D) Scatter plot representing EV number in reindeer plasma, showing some variation in plasma EV concentration between animals $(n=16)$. (E) Modal size of EVs in plasma of individual animals indicates some individual variation, with modal plasma EV size in the range of 110-150 nm, similar as seen in the NTA graphs in A; $(n=16)$. Error bar in D and E represents standard deviation (SD).

\subsection{PAD Protein Homologue and Deiminated Proteins in Reindeer Plasma and Plasma EVs}

Anti-human PAD2-, PAD3- and PAD4-specific antibodies were used in Western blotting for assessment of putative PAD protein homologues in reindeer, based on cross- 
reaction. A positive protein band at the expected approximate $70-75 \mathrm{kDa}$ size was identified for all three isozymes in plasma; in plasma EVs only PAD4 was positive, while neither PAD2 nor PAD3 where detected in plasma EVs (Figure 2A,B). To assess the presence of total deiminated proteins in plasma and plasma EVs, the F95-enriched fractions were silver stained, revealing protein bands between 25-250 kDa in plasma and 50-150 kDa in plasma EVs, respectively (Figure 2C).

A.

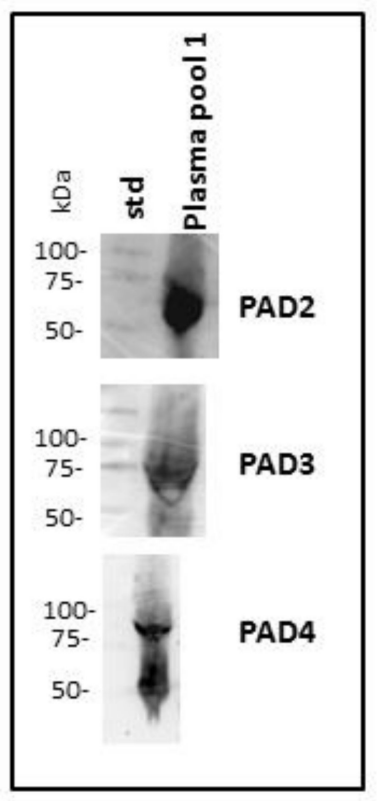

B.

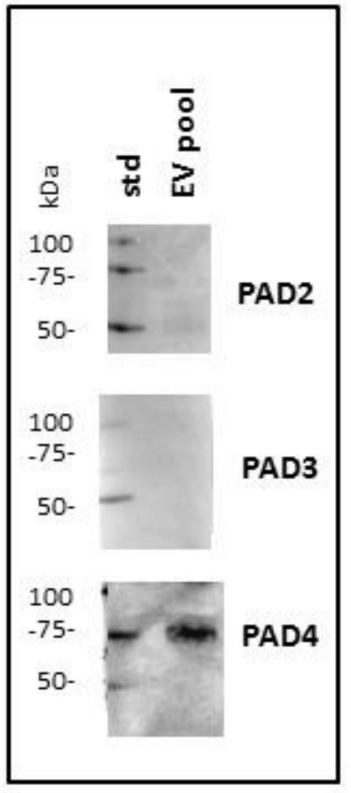

C.

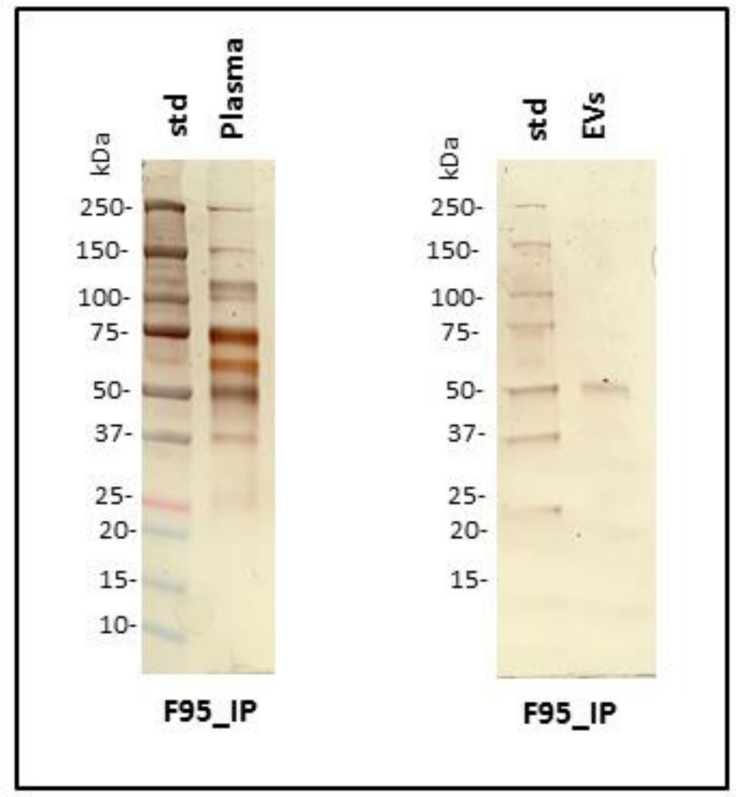

Figure 2. Peptidylarginine deiminase (PAD) isoforms and deiminated proteins in reindeer plasma and plasma EVs. (A) Positive bands identified in reindeer plasma at expected size range of approximately 70-75 kDa using anti-human PAD2, PAD3- and PAD4-specific antibodies (a pool of five plasma is represented). (B) In plasma EVs, PAD2 and PAD3 isozymes were not detected while a strong positive reaction for PAD4 was observed (EV pool from five animals). (C) F95-enriched IP fractions, representative of deiminated protein enrichment and isolated from reindeer plasma and plasma EVs, were stained with silverstaining following SDS-PAGE in 4-20\% TGX gels. The protein size standard (std) is indicated on the blots and gels in kilodaltons $(\mathrm{kDa})$.

Sequence alignment, followed by neighbor joining tree construction comparing known PAD isozyme sequences from deer (white-tailed deer, red deer) with cattle (Bos taurus) and human (Homo sapiens) PADs, further revealed that deer PAD isozymes align with other mammalian PADs (Figure 3). Based on percent identity matrix (using Clustal Omega 2.1), homology of PAD isozymes from deer (using the protein sequences from Odocoileus virginianus texanus) compared with human PADs was as follows: PAD1 78.88\%, PAD2 93.29\%, PAD3 87.71\%, PAD4 75.97\%, and PAD6 71.55\%.

\subsection{LC-MS/MS Analysis of Deiminated Proteins in Reindeer Plasma and Plasma EVs}

Identification of deiminated proteins in reindeer plasma and plasma EVs was carried out following F95 enrichment using LC-MS/MS analysis. Deiminated protein hits identified in EVs, showing both hits with R. tarandus and other Artiodactyla, are presented in Table 1 (for full detailed LC-MS/MS data on F95-enriched proteins from plasma EVs, see Supplementary Table S1). Deiminated protein hits identified in whole plasma, showing both hits with $R$. tarandus and other Artiodactyla, are presented in Table 2 (for full detailed LC-MS/MS data on F95-enriched proteins from whole plasma, see Supplementary Table S2). The number of deiminated protein hits identified in whole plasma and plasma EVs from Tables 1 and 2, as well as overlapping hits, are presented in the Venn diagram in Figure 4A. 


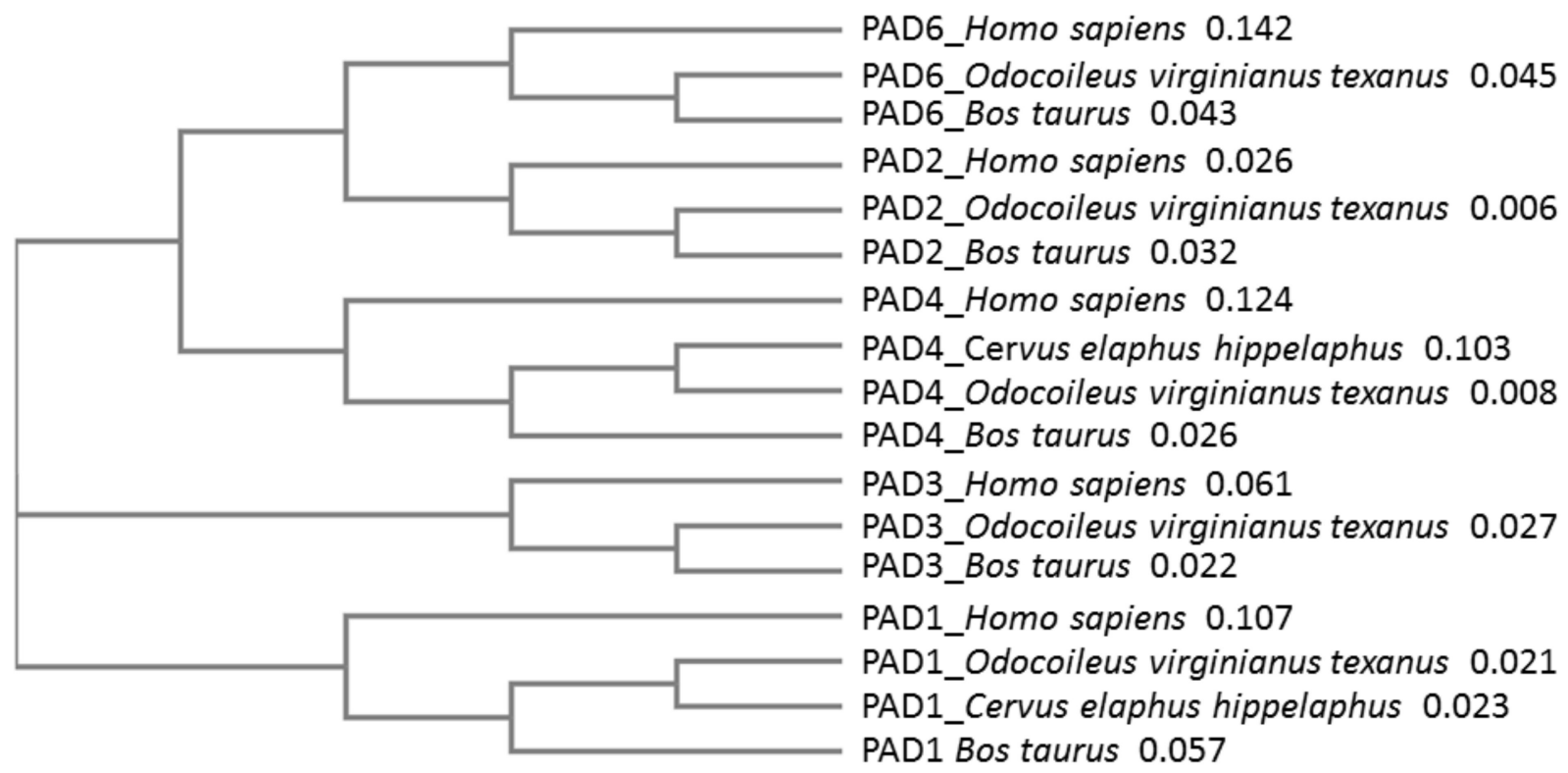

Figure 3. Phylogeny tree of known PADs from Artiodactyla, compared with human. White-tailed deer (Odocoileus virginianus texanus), red deer (Cervus elaphus hippelaphus) and cow (Bos taurus) peptidylarginine deiminase (PAD) isozymes were compared with human PADs. The following sequences were used for the neighbor joining tree construction (using Clustal Omega): Odocoileus virginianus texanus PAD1 (XP_020733655.1), PAD2 (XP_020733656.1), PAD3 (XP_020733658.1), PAD4 (XP_020754850.1) and PAD6 (XP_020754849.1) isozymes; Bos taurus PAD1 (NP_001094742.1), PAD2 (NP_001098922.1), PAD3 (XP_010800991.1), PAD4 (NP_001179102.1) and PAD6 (XP_002685843.1) isozymes; Cervus elaphus hippelaphus PAD1 (OWK12974.1) and PAD4 (OWK12644.1) isozymes; human (Homo sapiens) PAD1 (NP_037490.2), PAD2 (NP_031391.2), PAD3 (NP_057317.2), PAD4 (NP_036519.2) and PAD6 (NP_997304.3) isozymes. The numbers next to the species names represent a measure of support for the node.

Table 1. Deiminated proteins in plasma EVs of reindeer ( $R$. tarandus), identified by F95 enrichment and liquid chromatography with tandem mass spectrometry (LC-MS/MS) analysis. Proteins identified only in plasma EVs (and not in whole plasma) are highlighted in blue and with an asterix $(*)$; uncharacterized hits with a secondary hit that was annotated are included and indicated in brackets. Protein ID, protein name, species hit with the Artiodactyla UniProt database, number of matches and total score are included in the table. For full detailed LC-MS/MS data for F95-enriched proteins, see Supplementary Table S1.

\begin{tabular}{|c|c|c|c|}
\hline $\begin{array}{l}\text { Protein ID } \\
\text { Protein Name }\end{array}$ & $\begin{array}{l}\text { Species Name } \\
\text { Common Name }\end{array}$ & $\begin{array}{c}\text { Matches } \\
\text { (Sequences) }\end{array}$ & $\begin{array}{l}\text { Total Score } \\
(p<0.05)^{\dagger}\end{array}$ \\
\hline $\begin{array}{c}\text { A0A140T897_BOVIN } \\
\text { Albumin }\end{array}$ & $\begin{array}{l}\text { Bos taurus } \\
\text { Cow }\end{array}$ & $\begin{array}{c}2 \\
(39)\end{array}$ & 2322 \\
\hline $\begin{array}{l}\text { L8ISP4_9CETA } \\
\text { Serum albumin }\end{array}$ & $\begin{array}{c}\text { Bos mutus } \\
\text { Domestic Yak }\end{array}$ & $\begin{array}{l}107 \\
(37)\end{array}$ & 2198 \\
\hline $\begin{array}{c}\text { A0A4W2GW83_BOBOX } \\
\text { Uncharacterized protein (ALB protein) }\end{array}$ & $\begin{array}{c}\text { Bos indicus } x \text { Bos taurus } \\
\text { Zebu } \times \text { Cow }\end{array}$ & $\begin{array}{l}105 \\
(37)\end{array}$ & 2072 \\
\hline $\begin{array}{l}\text { A0A5N3XZ04_MUNRE } \\
\text { IF rod domain-containing protein }\end{array}$ & $\begin{array}{l}\text { Muntiacus reevesi } \\
\text { Chinese muntjac }\end{array}$ & $\begin{array}{c}44 \\
(25)\end{array}$ & 1128 \\
\hline
\end{tabular}


Table 1. Cont.

\begin{tabular}{|c|c|c|c|}
\hline $\begin{array}{l}\text { Protein ID } \\
\text { Protein Name }\end{array}$ & $\begin{array}{l}\text { Species Name } \\
\text { Common Name }\end{array}$ & $\begin{array}{c}\text { Matches } \\
\text { (Sequences) }\end{array}$ & $\begin{array}{l}\text { Total Score } \\
(p<0.05)^{+}\end{array}$ \\
\hline $\begin{array}{l}\text { *A0A212DF80_CEREH } \\
\text { KRT5 }\end{array}$ & $\begin{array}{l}\text { Cervus elaphus hippelaphus } \\
\text { European red deer }\end{array}$ & $\begin{array}{c}44 \\
(25)\end{array}$ & 1275 \\
\hline $\begin{array}{l}\text { A0A6J0WT46_ODOVR } \\
\text { Serum albumin }\end{array}$ & $\begin{array}{l}\text { Odocoileus virginianus texanus } \\
\text { White-tailed deer }\end{array}$ & $\begin{array}{c}52 \\
(22)\end{array}$ & 1177 \\
\hline $\begin{array}{c}\text { A0A5N4DHW9_CAMDR } \\
\text { Keratin }\end{array}$ & $\begin{array}{l}\text { Camelus dromedarius } \\
\text { Dromedary }\end{array}$ & $\begin{array}{c}40 \\
(21)\end{array}$ & 1116 \\
\hline $\begin{array}{c}\text { A0A4W2C021_BOBOX } \\
\text { Uncharacterized protein (collagen alpha-1(I) chain) }\end{array}$ & $\begin{array}{l}\text { Bos indicus } x \text { Bos taurus } \\
\text { Zebu } \times \text { Cow }\end{array}$ & $\begin{array}{c}34 \\
(20)\end{array}$ & 1080 \\
\hline $\begin{array}{c}\text { A0A452FHU9_CAPHI } \\
\text { Uncharacterized protein (collagen type I alpha } 1 \text { chain) }\end{array}$ & $\begin{array}{l}\text { Capra hircus } \\
\text { Goat }\end{array}$ & $\begin{array}{c}34 \\
(16)\end{array}$ & 988 \\
\hline $\begin{array}{c}\text { A0A5N3WTF4_MUNMU } \\
\text { Uncharacterized protein (collagen alpha-1(I) chain isoform X1) }\end{array}$ & $\begin{array}{l}\text { Muntiacus muntjac } \\
\text { Barking deer }\end{array}$ & $\begin{array}{c}23 \\
(13)\end{array}$ & 976 \\
\hline $\begin{array}{c}\text { A0A5N4D320_CAMDR } \\
\text { Keratin }\end{array}$ & $\begin{array}{l}\text { Camelus dromedarius } \\
\text { Dromedary }\end{array}$ & $\begin{array}{c}37 \\
(15)\end{array}$ & 832 \\
\hline $\begin{array}{l}\text { A0A6J0WBI9_ODOVR } \\
\text { Histidine-rich glycoprotein isoform X1 }\end{array}$ & $\begin{array}{c}\text { Odocoileus virginianus texanus } \\
\text { White-tailed deer }\end{array}$ & $\begin{array}{c}33 \\
(14)\end{array}$ & 806 \\
\hline $\begin{array}{c}{ }^{*} \mathbf{A} \text { 0A212D793_CEREH } \\
\text { KRT19 }\end{array}$ & $\begin{array}{l}\text { Cervus elaphus hippelaphus } \\
\text { European red deer }\end{array}$ & $\begin{array}{c}32 \\
(13)\end{array}$ & 785 \\
\hline $\begin{array}{l}\text { A0A287B5W2_PIG } \\
\text { Trypsinogen isoform X1 }\end{array}$ & $\begin{array}{l}\text { Sus scrofa } \\
\text { Wild boar }\end{array}$ & $\begin{array}{c}185 \\
(157)\end{array}$ & 765 \\
\hline $\begin{array}{c}\text { A0A4W2D3K5_BOBOX } \\
\text { Keratin } 75\end{array}$ & $\begin{array}{c}\text { Bos indicus } x \text { Bos taurus } \\
\text { Zebu } \times \text { Cow }\end{array}$ & $\begin{array}{c}33 \\
(13)\end{array}$ & 729 \\
\hline $\begin{array}{c}\text { A0A4W2DIS9_BOBOX } \\
\text { Keratin } 75\end{array}$ & $\begin{array}{c}\text { Bos indicus } x \text { Bos taurus } \\
\text { Zebu } \times \text { Cow }\end{array}$ & $\begin{array}{c}31 \\
(15)\end{array}$ & 724 \\
\hline $\begin{array}{c}\text { A0A6B0R6W5_9CETA } \\
\text { Uncharacterized protein (IF rod domain-containing; glial } \\
\text { fibrillary acidic protein) }\end{array}$ & $\begin{array}{c}\text { Bos mutus } \\
\text { Domestic yak }\end{array}$ & $\begin{array}{l}25 \\
(14)\end{array}$ & 704 \\
\hline $\begin{array}{c}\text { 9XAP9_CAMFR } \\
\text { Keratin, type I cytoskeletal 14-like protein }\end{array}$ & $\begin{array}{l}\text { Camelus ferus } \\
\text { Wild Bactrian camel }\end{array}$ & $\begin{array}{c}24 \\
(10)\end{array}$ & 694 \\
\hline $\begin{array}{c}\text { A0A452FN18_CAPHI } \\
\text { IF rod domain-containing protein }\end{array}$ & $\begin{array}{l}\text { Capra hircus } \\
\text { Goat }\end{array}$ & $\begin{array}{l}13 \\
(9)\end{array}$ & 676 \\
\hline $\begin{array}{c}\text { A0A5N4DGN6_CAMDR } \\
\text { Keratin }\end{array}$ & $\begin{array}{l}\text { Camelus dromedarius } \\
\text { Dromedary }\end{array}$ & $\begin{array}{c}29 \\
(14)\end{array}$ & 670 \\
\hline $\begin{array}{c}\text { A0A4W2IN22_BOBOX } \\
\text { IF rod domain-containing protein }\end{array}$ & $\begin{array}{c}\text { Bos indicus } x \text { Bos taurus } \\
\text { Zebu } \times \text { Cow }\end{array}$ & $\begin{array}{c}25 \\
(11)\end{array}$ & 670 \\
\hline $\begin{array}{c}\text { A0A6I9IRH0_VICPA } \\
\text { keratin, type I cytoskeletal }\end{array}$ & $\begin{array}{l}\text { Vicugna pacos } \\
\text { Alpaca }\end{array}$ & $\begin{array}{l}10 \\
(8)\end{array}$ & 667 \\
\hline $\begin{array}{c}\text { A0A5G2QXD3_PIG } \\
\text { IF rod domain-containing protein }\end{array}$ & $\begin{array}{l}\text { Sus scrofa } \\
\text { Wild boar }\end{array}$ & $\begin{array}{c}27 \\
(18)\end{array}$ & 655 \\
\hline $\begin{array}{l}\text { *A0A3Q1LZN8_BOVIN } \\
\text { Collagen alpha-2(I) chain }\end{array}$ & $\begin{array}{l}\text { Bos taurus } \\
\text { Cow }\end{array}$ & $\begin{array}{c}26 \\
(13)\end{array}$ & 634 \\
\hline $\begin{array}{c}\text { A0A287BLD2_PIG } \\
\begin{array}{c}\text { Uncharacterized protein (collagen alpha-1(I) chain preproprotein; } \\
\text { alpha } 1 \text { chain of type I collagen) }\end{array}\end{array}$ & $\begin{array}{l}\text { Sus scrofa } \\
\text { Wild boar }\end{array}$ & $\begin{array}{l}19 \\
(9)\end{array}$ & 628 \\
\hline
\end{tabular}


Table 1. Cont.

\begin{tabular}{|c|c|c|c|}
\hline $\begin{array}{c}\text { Protein ID } \\
\text { Protein Name }\end{array}$ & $\begin{array}{l}\text { Species Name } \\
\text { Common Name }\end{array}$ & $\begin{array}{c}\text { Matches } \\
\text { (Sequences) }\end{array}$ & $\begin{array}{l}\text { Total Score } \\
(p<0.05)^{+}\end{array}$ \\
\hline $\begin{array}{c}{ }^{\text {*A0A212D6S5_CEREH }} \\
\text { KRT17 }\end{array}$ & $\begin{array}{l}\text { Cervus elaphus hippelaphus } \\
\text { European red deer }\end{array}$ & $\begin{array}{c}16 \\
(11)\end{array}$ & 580 \\
\hline $\begin{array}{c}\text { A0A5N4DFY6_CAMDR } \\
\text { Keratin }\end{array}$ & $\begin{array}{l}\text { Camelus dromedarius } \\
\text { Dromedary }\end{array}$ & $\begin{array}{c}19 \\
(12)\end{array}$ & 550 \\
\hline $\begin{array}{c}\text { A0A212CMY9_CEREH } \\
\begin{array}{l}\text { Uncharacterized protein (immunoglobulin heavy constant; } \\
\text { beta-2-microglobulin) }\end{array}\end{array}$ & $\begin{array}{l}\text { Cervus elaphus hippelaphus } \\
\text { European red deer }\end{array}$ & $\begin{array}{l}10 \\
(8)\end{array}$ & 539 \\
\hline $\begin{array}{l}\text { *A0A6J3QLJ4_TURTR } \\
\text { Collagen alpha-1(I) chain }\end{array}$ & $\begin{array}{c}\text { Tursiops truncates } \\
\text { Common bottlenose dolphin }\end{array}$ & $\begin{array}{c}9 \\
(7)\end{array}$ & 488 \\
\hline $\begin{array}{c}\text { A0A2Y9SJP9_PHYMC } \\
\text { Keratin, type II cytoskeletal } 6 \mathrm{~A}\end{array}$ & $\begin{array}{l}\text { Physeter macrocephalus } \\
\text { Sperm Whale }\end{array}$ & $\begin{array}{c}26 \\
(10)\end{array}$ & 469 \\
\hline $\begin{array}{c}\text { A0A452EP10_CAPHI } \\
\text { IF rod domain-containing protein }\end{array}$ & $\begin{array}{l}\text { Capra hircus } \\
\text { Goat }\end{array}$ & $\begin{array}{c}9 \\
(7)\end{array}$ & 469 \\
\hline $\begin{array}{c}\text { A0A6B0R542_9CETA } \\
\text { Uncharacterized protein } \\
\text { (bradykinin; kininogen-1; kininogen-2) }\end{array}$ & $\begin{array}{l}\text { Bos mutus } \\
\text { Wild yak }\end{array}$ & $\begin{array}{l}16 \\
(8)\end{array}$ & 466 \\
\hline $\begin{array}{c}\text { A0A5N4DG47_CAMDR } \\
\text { Keratin }\end{array}$ & $\begin{array}{l}\text { Camelus dromedarius } \\
\text { Dromedary }\end{array}$ & $\begin{array}{l}19 \\
(9)\end{array}$ & 463 \\
\hline $\begin{array}{c}\text { A0A5N3WDS4_MUNMU } \\
\text { Bradykinin }\end{array}$ & $\begin{array}{l}\text { Muntiacus muntjac } \\
\text { Barking deer }\end{array}$ & $\begin{array}{l}10 \\
(9)\end{array}$ & 443 \\
\hline $\begin{array}{c}\text { *A0A1S7J1Y9_PIG } \\
\text { Alpha2 chain of type I collagen }\end{array}$ & $\begin{array}{l}\text { Sus scrofa } \\
\text { Wild boar }\end{array}$ & $\begin{array}{c}17 \\
(10)\end{array}$ & 442 \\
\hline $\begin{array}{c}\text { A0A5N4DFY1_CAMDR } \\
\text { Keratin }\end{array}$ & $\begin{array}{l}\text { Camelus dromedarius } \\
\text { Dromedary }\end{array}$ & $\begin{array}{l}13 \\
(8)\end{array}$ & 380 \\
\hline $\begin{array}{c}\text { A0A383ZWF6_BALAS } \\
\text { Keratin, type II cytoskeletal } 6 \text { A-like isoform X2 }\end{array}$ & $\begin{array}{l}\text { Balaenoptera acutorostrata } \\
\text { scammoni } \\
\text { Minke whale }\end{array}$ & $\begin{array}{l}13 \\
(8)\end{array}$ & 360 \\
\hline $\begin{array}{c}\text { W5Q4S0_SHEEP } \\
\text { Uncharacterized protein (collagen alpha-1(III) chain; collagen } \\
\text { type III alpha } 1 \text { chain; fibrillar collagen NC1 } \\
\text { domain-containing protein) }\end{array}$ & $\begin{array}{l}\text { Ovis aries } \\
\text { Sheep }\end{array}$ & $\begin{array}{c}7 \\
(5)\end{array}$ & 340 \\
\hline $\begin{array}{c}\text { A0A2F0AVL6_ESCRO } \\
\text { Keratin, type II cytoskeletal } 4 \\
\end{array}$ & $\begin{array}{l}\text { Eschrichtius robustus } \\
\text { Gray whale }\end{array}$ & $\begin{array}{l}12 \\
(7)\end{array}$ & 339 \\
\hline $\begin{array}{c}\text { *A0A5N3W3N9_MUNRE } \\
\text { SH3 domain-containing protein }\end{array}$ & $\begin{array}{l}\text { Muntiacus reevesi } \\
\text { Chinese muntjac }\end{array}$ & $\begin{array}{c}8 \\
(8)\end{array}$ & 296 \\
\hline $\begin{array}{c}\text { A0A340XVM8_LIPVE } \\
\text { Keratin, type I cytoskeletal } 15\end{array}$ & $\begin{array}{l}\text { Lipotes vexillifer } \\
\text { Baiji }\end{array}$ & $\begin{array}{l}10 \\
(6)\end{array}$ & 294 \\
\hline $\begin{array}{c}\text { A0A5N4CT25_CAMDR } \\
\text { Histone H4 }\end{array}$ & $\begin{array}{l}\text { Camelus dromedarius } \\
\text { Dromedary }\end{array}$ & $\begin{array}{l}5 \\
(5)\end{array}$ & 240 \\
\hline $\begin{array}{c}\text { A0A5N3XAC4_MUNRE } \\
\text { Uncharacterized protein (Ig-likedomain-containing protein) }\end{array}$ & $\begin{array}{l}\text { Muntiacus reevesi } \\
\text { Chinese muntjac }\end{array}$ & $\begin{array}{c}7 \\
(3)\end{array}$ & 239 \\
\hline $\begin{array}{l}\text { A0A6J0ZDI0_ODOVR } \\
\text { Serotransferrin }\end{array}$ & $\begin{array}{l}\text { Odocoileus virginianus texanus } \\
\text { White-tailed deer }\end{array}$ & $\begin{array}{l}5 \\
(5)\end{array}$ & 234 \\
\hline $\begin{array}{l}\text { *ACTB_BOSMU } \\
\text { Actin, cytoplasmic } 1\end{array}$ & $\begin{array}{c}\text { Bos mutus grunniens } \\
\text { Wild yak }\end{array}$ & $\begin{array}{c}6 \\
(5)\end{array}$ & 232 \\
\hline $\begin{array}{l}\text { A0A5N3WEA4_MUNMU } \\
\text { Beta-1 metal-binding globulin }\end{array}$ & $\begin{array}{l}\text { Muntiacus muntjac } \\
\text { Barking deer }\end{array}$ & $\begin{array}{c}5 \\
(5)\end{array}$ & 232 \\
\hline
\end{tabular}


Table 1. Cont.

\begin{tabular}{|c|c|c|c|}
\hline $\begin{array}{l}\text { Protein ID } \\
\text { Protein Name }\end{array}$ & $\begin{array}{l}\text { Species Name } \\
\text { Common Name }\end{array}$ & $\begin{array}{c}\text { Matches } \\
\text { (Sequences) }\end{array}$ & $\begin{array}{l}\text { Total Score } \\
(p<0.05)^{+}\end{array}$ \\
\hline $\begin{array}{c}\text { A0A6J0XRB4_ODOVR } \\
\text { Keratin, type II cytoskeletal } 2 \text { oral-like }\end{array}$ & $\begin{array}{c}\text { Odocoileus virginianus texanus } \\
\text { White-tailed deer }\end{array}$ & $\begin{array}{l}16 \\
(6)\end{array}$ & 228 \\
\hline $\begin{array}{l}\text { A0A2C9F3E9_PIG } \\
\text { Junction plakoglobin }\end{array}$ & Sus scrofa & $\begin{array}{c}6 \\
(1)\end{array}$ & 228 \\
\hline $\begin{array}{c}\text { A0A212DB90_CEREH } \\
\text { Ig-like domain-containing protein }\end{array}$ & $\begin{array}{l}\text { Cervus elaphus hippelaphus } \\
\text { European red deer }\end{array}$ & $\begin{array}{c}6 \\
(3)\end{array}$ & 225 \\
\hline $\begin{array}{c}\text { *0A6I9IE32_VICPA } \\
\text { Collagen alpha-1(III) chain isoform X1 }\end{array}$ & $\begin{array}{l}\text { Vicugna pacos } \\
\text { Alpaca }\end{array}$ & $\begin{array}{c}6 \\
(4)\end{array}$ & 224 \\
\hline $\begin{array}{l}\text { A0A212D5P4_CEREH } \\
\text { TAF domain-containing protein }\end{array}$ & $\begin{array}{l}\text { Cervus elaphus hippelaphus } \\
\text { European red deer }\end{array}$ & $\begin{array}{l}5 \\
(5)\end{array}$ & 222 \\
\hline $\begin{array}{c}\text { A0A643C4S8_BALPH } \\
\text { Uncharacterized protein (IF rod domain-containing protein; } \\
\text { KRT81; Keratin } 85)\end{array}$ & $\begin{array}{l}\text { Balaenoptera physalus } \\
\text { Fin Whale }\end{array}$ & $\begin{array}{l}10 \\
(6)\end{array}$ & 215 \\
\hline $\begin{array}{c}\text { A0A5N3W8P2_MUNMU } \\
\text { Uncharacterized protein (Ig-likedomain-containing protein) }\end{array}$ & $\begin{array}{l}\text { Muntiacus muntjac } \\
\text { Reeves's muntjac }\end{array}$ & $\begin{array}{c}7 \\
(3)\end{array}$ & 212 \\
\hline $\begin{array}{l}\text { A0A212D7J2_CEREH } \\
\text { Fibrinogen beta chain }\end{array}$ & $\begin{array}{l}\text { Cervus elaphus hippelaphus } \\
\text { European red deer }\end{array}$ & $\begin{array}{l}3 \\
(3)\end{array}$ & 192 \\
\hline $\begin{array}{c}\text { A0A287B7K6_PIG } \\
\text { IF rod domain-containing protein }\end{array}$ & $\begin{array}{l}\text { Sus scrofa } \\
\text { Wild boar }\end{array}$ & $\begin{array}{l}9 \\
(6)\end{array}$ & 186 \\
\hline $\begin{array}{c}\text { A0A212DFA6_CEREH } \\
\text { IF rod domain-containing protein }\end{array}$ & $\begin{array}{l}\text { Cervus elaphus hippelaphus } \\
\text { European red deer }\end{array}$ & $\begin{array}{l}11 \\
(5)\end{array}$ & 184 \\
\hline $\begin{array}{l}\text { A0A6J0XD83_ODOVR } \\
\text { Fibrinogen alpha chain }\end{array}$ & $\begin{array}{c}\text { Odocoileus virginianus texanus } \\
\text { White-tailed deer }\end{array}$ & $\begin{array}{c}5 \\
(4)\end{array}$ & 180 \\
\hline $\begin{array}{l}\text { *A0A2Y9MPQ9_DELLE } \\
\text { Collagen alpha-1(III) chain }\end{array}$ & $\begin{array}{c}\text { Delphinapterus leucas } \\
\text { Beluga whale }\end{array}$ & $\begin{array}{c}5 \\
(4)\end{array}$ & 163 \\
\hline $\begin{array}{c}\text { A0A452E8D3_CAPHI } \\
\text { Ig-like domain-containing protein }\end{array}$ & $\begin{array}{l}\text { Capra hircus } \\
\text { Goat }\end{array}$ & $\begin{array}{l}3 \\
(2)\end{array}$ & 149 \\
\hline $\begin{array}{c}\text { W5P2K5_SHEEP } \\
\text { IF rod domain-containing protein }\end{array}$ & $\begin{array}{l}\text { Ovis aries } \\
\text { Sheep }\end{array}$ & $\begin{array}{c}7 \\
(4) \\
\end{array}$ & 147 \\
\hline $\begin{array}{c}\text { A0A5N3UHT3_MUNRE } \\
\text { Ig-like domain-containing protein }\end{array}$ & $\begin{array}{l}\text { Muntiacus reevesi } \\
\text { Chinese muntjac }\end{array}$ & $\begin{array}{c}2 \\
(2)\end{array}$ & 147 \\
\hline $\begin{array}{c}\text { A2P2I1_SHEEP } \\
\text { VH region }\end{array}$ & $\begin{array}{l}\text { Ovis aries } \\
\text { Sheep }\end{array}$ & $\begin{array}{c}1 \\
(1)\end{array}$ & 131 \\
\hline $\begin{array}{c}{ }^{*} \mathbf{Q} 0 \mathbf{V C X} \mathbf{2} \text { I BIP_BOVIN } \\
\text { Endoplasmic reticulum chaperone BiP }\end{array}$ & $\begin{array}{l}\text { Bos taurus } \\
\text { Cow }\end{array}$ & $\begin{array}{c}2 \\
(2)\end{array}$ & 101 \\
\hline $\begin{array}{l}\text { A0A212CAL2_CEREH } \\
\text { Elongation factor 1-alpha }\end{array}$ & $\begin{array}{l}\text { Cervus elaphus hippelaphus } \\
\text { European red deer }\end{array}$ & $\begin{array}{c}2 \\
(2)\end{array}$ & 100 \\
\hline $\begin{array}{l}\text { A0A5N3UV43_MUNMU } \\
\text { IF rod domain-containing protein }\end{array}$ & $\begin{array}{l}\text { Muntiacus muntjac } \\
\text { Barking deer }\end{array}$ & $\begin{array}{c}5 \\
(2)\end{array}$ & 89 \\
\hline $\begin{array}{c}\text { A0A3Q1LUE9_BOVIN } \\
\text { Ig-like domain-containing protein }\end{array}$ & $\begin{array}{l}\text { Bos taurus } \\
\text { Cow }\end{array}$ & $\begin{array}{c}1 \\
(1)\end{array}$ & 87 \\
\hline $\begin{array}{l}\text { A0A6B9SDT6_BOVIN } \\
\text { Ig lamda chain variable region }\end{array}$ & $\begin{array}{l}\text { Bos taurus } \\
\text { Cow }\end{array}$ & $\begin{array}{c}1 \\
(1)\end{array}$ & 87 \\
\hline $\begin{array}{c}\text { A0A212CSZ9_CEREH } \\
\text { Ig-like domain-containing protein }\end{array}$ & $\begin{array}{l}\text { Cervus elaphus hippelaphus } \\
\text { European red deer }\end{array}$ & $\begin{array}{c}2 \\
(1)\end{array}$ & 83 \\
\hline
\end{tabular}


Table 1. Cont.

\begin{tabular}{|c|c|c|c|}
\hline $\begin{array}{c}\text { Protein ID } \\
\text { Protein Name }\end{array}$ & $\begin{array}{l}\text { Species Name } \\
\text { Common Name }\end{array}$ & $\begin{array}{c}\text { Matches } \\
\text { (Sequences) }\end{array}$ & $\begin{array}{l}\text { Total Score } \\
(p<0.05)^{\dagger}\end{array}$ \\
\hline $\begin{array}{c}\text { A0A2F0B9E6_ESCRO } \\
\text { Trypsin }\end{array}$ & $\begin{array}{l}\text { Eschrichtius robustus } \\
\text { Gray whale }\end{array}$ & $\begin{array}{c}2 \\
(1)\end{array}$ & 80 \\
\hline $\begin{array}{c}\text { *A0A286ZKC5_PIG } \\
\text { HATPase_c domain-containing protein }\end{array}$ & $\begin{array}{l}\text { Sus scrofa } \\
\text { Wild boar }\end{array}$ & $\begin{array}{c}2 \\
(0)\end{array}$ & 76 \\
\hline $\begin{array}{c}\text { A0A1L6BP13_BUBBU } \\
\text { Beta-casein }\end{array}$ & $\begin{array}{l}\text { Bubalus bubalis } \\
\text { Water buffalo }\end{array}$ & $\begin{array}{l}3 \\
(2)\end{array}$ & 75 \\
\hline $\begin{array}{c}\text { A0A6B0S2F2_9CETA } \\
\text { Fibrinogen C-terminal domain-containing protein }\end{array}$ & $\begin{array}{l}\text { Bos mutus } \\
\text { Wild yak }\end{array}$ & $\begin{array}{c}3 \\
(2)\end{array}$ & 68 \\
\hline $\begin{array}{c}\text { *P0C276 I RL40_SHEEP } \\
\text { Ubiquitin-60S ribosomal protein L40 }\end{array}$ & $\begin{array}{l}\text { Ovis aries } \\
\text { Sheep }\end{array}$ & $\begin{array}{c}1 \\
(1)\end{array}$ & 67 \\
\hline $\begin{array}{c}\text { *A0A2Y9SBW8_PHYMC } \\
\text { Histone } H 2 B\end{array}$ & $\begin{array}{l}\text { Physeter macrocephalus } \\
\text { Sperm Whale }\end{array}$ & $\begin{array}{l}2 \\
(2)\end{array}$ & 65 \\
\hline $\begin{array}{c}\text { A0A6B0RTH8_9CETA } \\
\text { Uncharacterized protein (obscurin) }\end{array}$ & $\begin{array}{l}\text { Bos mutus } \\
\text { Wild yak }\end{array}$ & $\begin{array}{c}2 \\
(2)\end{array}$ & 63 \\
\hline $\begin{array}{c}\text { A0A6J3S691_TURTR } \\
\text { Keratin, type II cytoskeletal } 78\end{array}$ & $\begin{array}{c}\text { Tursiops truncates } \\
\text { Common bottlenose dolphin }\end{array}$ & $\begin{array}{c}2 \\
(2)\end{array}$ & 63 \\
\hline $\begin{array}{c}\text { A0A383ZRF2_BALAS } \\
\text { Keratin, type I cytoskeletal } 24\end{array}$ & $\begin{array}{c}\text { Balaenoptera acutorostrata scammony } \\
\text { Minke whale }\end{array}$ & $\begin{array}{c}1 \\
(1)\end{array}$ & 62 \\
\hline $\begin{array}{l}\text { *A0A0C5AGQ3_BUBBU } \\
\text { Lysozyme }\end{array}$ & $\begin{array}{l}\text { Bubalus bubalis } \\
\text { Water buffalo }\end{array}$ & $\begin{array}{c}1 \\
(1)\end{array}$ & 61 \\
\hline $\begin{array}{c}\text { A2P2I3_SHEEP } \\
\text { VH region }\end{array}$ & $\begin{array}{l}\text { Ovis aries } \\
\text { Sheep }\end{array}$ & $\begin{array}{c}1 \\
(1)\end{array}$ & 60 \\
\hline $\begin{array}{c}\text { A0A075B7I6_PIG } \\
\text { Ig-like domain-containing protein }\end{array}$ & $\begin{array}{l}\text { Sus scrofa } \\
\text { Wild boar }\end{array}$ & $\begin{array}{c}1 \\
(1)\end{array}$ & 59 \\
\hline $\begin{array}{l}\text { A0A0R4I993_SUSBA } \\
\text { Tubulin alpha chain }\end{array}$ & $\begin{array}{l}\text { Sus barbatus } \\
\text { Bornean bearded pig }\end{array}$ & $\begin{array}{c}1 \\
(1)\end{array}$ & 53 \\
\hline $\begin{array}{c}\text { A0A5N4EAI9_CAMDR } \\
\text { Annexin }\end{array}$ & $\begin{array}{l}\text { Camelus dromedarius } \\
\text { Dromedary }\end{array}$ & $\begin{array}{c}2 \\
(2)\end{array}$ & 50 \\
\hline $\begin{array}{l}\text { A0A2Y9EH04_PHYMC } \\
\text { Fer-1-like protein } 4\end{array}$ & $\begin{array}{l}\text { Physeter macrocephalus } \\
\text { Sperm Whale }\end{array}$ & $\begin{array}{c}2 \\
(2) \\
\end{array}$ & 50 \\
\hline $\begin{array}{c}\text { A0A5J5N0U1_MUNRE } \\
\text { Uncharacterized protein (small proline-rich protein 2I-like; } \\
\text { Type II small proline-rich protein) }\end{array}$ & $\begin{array}{l}\text { Muntiacus reevesi } \\
\text { Chinese muntjac }\end{array}$ & $\begin{array}{c}1 \\
(1)\end{array}$ & 50 \\
\hline $\begin{array}{c}\text { A0A6B0R269_9CETA } \\
\text { Ig-like domain-containing protein }\end{array}$ & $\begin{array}{l}\text { Bos mutus } \\
\text { Wild yak }\end{array}$ & $\begin{array}{c}2 \\
(1)\end{array}$ & 49 \\
\hline $\begin{array}{c}\text { A0A452E907_CAPHI } \\
\text { Uncharacterized protein (skin-specific protein 32; Chromosome } 3 \\
\text { C1orf68 homolog; Chromosome } 1 \text { open reading frame 68) }\end{array}$ & $\begin{array}{l}\text { Capra hircus } \\
\text { Goat }\end{array}$ & $\begin{array}{c}1 \\
(1)\end{array}$ & 48 \\
\hline $\begin{array}{c}\text { A0A4W2E476_BOBOX } \\
\text { Ig-like domain-containing protein }\end{array}$ & $\begin{array}{c}\text { Bos indicus } x \text { Bos taurus } \\
\text { Zebu } \times \text { Cow }\end{array}$ & $\begin{array}{c}1 \\
(1)\end{array}$ & 48 \\
\hline $\begin{array}{c}\text { A0A212CS30_CEREH } \\
\text { Ig-like domain-containing protein }\end{array}$ & $\begin{array}{l}\text { Cervus elaphus hippelaphus } \\
\text { European red deer }\end{array}$ & $\begin{array}{c}2 \\
(1)\end{array}$ & 47 \\
\hline
\end{tabular}

+ Ions score is $-10^{*} \log (\mathrm{P})$, where $\mathrm{P}$ is the probability that the observed match is a random event. Individual ions scores $>46$ indicate identity or extensive homology $(p<0.05)$. Protein scores are derived from ions scores as a non-probabilistic basis for ranking protein hits. 
Table 2. Deiminated proteins in whole plasma of reindeer (Rangifer tarandus) identified by F95 enrichment and liquid chromatography with tandem mass spectrometry (LC-MS/MS) analysis. Proteins identified only in whole plasma (and not in plasma EVs) are highlighted in pink and with an asterix $\left(^{*}\right)$; uncharacterized hits with a secondary hit that was annotated are included and indicated in brackets. Protein ID, protein name, species hit with the Artiodactyla UniProt database, number of matches and total score are included in the table. For full detailed LC-MS/MS data on F95-enriched proteins, see Supplementary Table S2.

\begin{tabular}{|c|c|c|c|}
\hline $\begin{array}{l}\text { Protein ID } \\
\text { Protein Name }\end{array}$ & $\begin{array}{l}\text { Species Name } \\
\text { Common Name }\end{array}$ & $\begin{array}{c}\text { Matches } \\
\text { (Sequences) }\end{array}$ & $\begin{array}{l}\text { Total Score } \\
(p<0.05)^{+}\end{array}$ \\
\hline $\begin{array}{l}\text { *A0A6J0ZEI2_ODOVR } \\
\text { Complement C3 }\end{array}$ & $\begin{array}{c}\text { Odocoileus virginianus texanus } \\
\text { White-tailed deer }\end{array}$ & $\begin{array}{c}71 \\
(51)\end{array}$ & 3535 \\
\hline 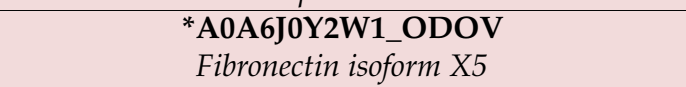 & $\begin{array}{c}\text { Odocoileus virginianus texanus } \\
\text { White-tailed deer }\end{array}$ & $\begin{array}{c}70 \\
(50)\end{array}$ & 3454 \\
\hline $\begin{array}{c}\text { *A0A5N3WRA9_MUNMU } \\
\text { C3-beta-c }\end{array}$ & $\begin{array}{l}\text { Muntiacus muntjac } \\
\text { Barking deer }\end{array}$ & $\begin{array}{c}70 \\
(51)\end{array}$ & 3438 \\
\hline $\begin{array}{c}\text { *A0A6J0YF65_ODOVR } \\
\text { alpha-2-macroglobulin }\end{array}$ & $\begin{array}{c}\text { Odocoileus virginianus texanus } \\
\text { White-tailed deer }\end{array}$ & $\begin{array}{c}43 \\
(37)\end{array}$ & 2929 \\
\hline $\begin{array}{c}\text { A0A140T897_BOVIN } \\
\text { Albumin }\end{array}$ & $\begin{array}{l}\text { Bos taurus } \\
\text { Cow }\end{array}$ & $\begin{array}{c}81 \\
(59)\end{array}$ & 2831 \\
\hline $\begin{array}{c}\text { A0A5J5N929_MUNRE } \\
\text { Uncharacterized protein (alpha-2-macroglobulin-like) }\end{array}$ & $\begin{array}{l}\text { Muntiacus reevesi } \\
\text { Chinese muntjac }\end{array}$ & $\begin{array}{c}59 \\
(42)\end{array}$ & 2815 \\
\hline $\begin{array}{l}\text { L8ISP4_9CETA } \\
\text { Serum albumin }\end{array}$ & $\begin{array}{c}\text { Bos mutus } \\
\text { Domestic Yak }\end{array}$ & $\begin{array}{c}79 \\
(58)\end{array}$ & 2691 \\
\hline $\begin{array}{c}\text { *A0A6J0YGQ5_ODOVR } \\
\text { Pregnancy zone protein-like isoform X1 }\end{array}$ & $\begin{array}{c}\text { Odocoileus virginianus texanus } \\
\text { White-tailed deer }\end{array}$ & $\begin{array}{c}49 \\
(38)\end{array}$ & 2596 \\
\hline $\begin{array}{l}\text { A0A6J0WT46_ODOVR } \\
\text { Serum albumin }\end{array}$ & $\begin{array}{l}\text { Odocoileus virginianus texanus } \\
\text { White-tailed deer }\end{array}$ & $\begin{array}{l}99 \\
(66)\end{array}$ & 2581 \\
\hline $\begin{array}{l}\text { A0A6J0ZDI0_ODOVR } \\
\text { Serotransferrin }\end{array}$ & $\begin{array}{l}\text { Odocoileus virginianus texanus } \\
\text { White-tailed deer }\end{array}$ & $\begin{array}{c}77 \\
(49)\end{array}$ & 2452 \\
\hline $\begin{array}{l}\text { A0A5N3XN56_MUNRE } \\
\text { Beta-1 metal-binding globulin }\end{array}$ & $\begin{array}{l}\text { Muntiacus reevesi } \\
\text { Chinese muntjac }\end{array}$ & $\begin{array}{c}65 \\
(44)\end{array}$ & 2268 \\
\hline $\begin{array}{c}\text { A0A212D5P0_CEREH } \\
A L B\end{array}$ & $\begin{array}{l}\text { Cervus elaphus hippelaphus } \\
\text { European red deer }\end{array}$ & $\begin{array}{c}84 \\
(56)\end{array}$ & 2237 \\
\hline $\begin{array}{l}\text { X2GM95_CERNI } \\
\text { Serum albumin }\end{array}$ & $\begin{array}{l}\text { Cervus nippon } \\
\text { Sika deer }\end{array}$ & $\begin{array}{c}82 \\
(54)\end{array}$ & 2182 \\
\hline $\begin{array}{l}\text { A0A6J0XGG0_ODOVR } \\
\text { Fibrinogen beta chain }\end{array}$ & $\begin{array}{l}\text { Odocoileus virginianus texanus } \\
\text { White-tailed deer }\end{array}$ & $\begin{array}{c}63 \\
(47)\end{array}$ & 1890 \\
\hline $\begin{array}{l}\text { A0A6J0XD83_ODOVR } \\
\text { Fibrinogen alpha chain }\end{array}$ & $\begin{array}{l}\text { Odocoileus virginianus texanus } \\
\text { White-tailed deer }\end{array}$ & $\begin{array}{c}62 \\
(42)\end{array}$ & 1770 \\
\hline $\begin{array}{c}\text { A0A5N3WDS4_MUNMU } \\
\text { Bradykinin }\end{array}$ & Muntiacus muntjac & $\begin{array}{c}76 \\
(49)\end{array}$ & 1754 \\
\hline $\begin{array}{c}\text { *A0A6J0WDQ8_ODOVR } \\
\text { Kininogen-1 isoform X1 }\end{array}$ & Odocoileus virginianus texanus & $\begin{array}{c}72 \\
(46)\end{array}$ & 1645 \\
\hline $\begin{array}{c}\text { *A0A6J0WBI9_ODOVR } \\
\text { Histidine-rich glycoprotein isoform X1 }\end{array}$ & Odocoileus virginianus texanus & $\begin{array}{l}152 \\
(95)\end{array}$ & 1514 \\
\hline $\begin{array}{c}\text { A0A5N3WD93_MUNMU } \\
\text { Fibrinogen C-terminal domain-containing protein }\end{array}$ & $\begin{array}{l}\text { Muntiacus muntjac } \\
\text { Barking deer }\end{array}$ & $\begin{array}{c}54 \\
(43)\end{array}$ & 1470 \\
\hline $\begin{array}{c}\text { *A0A212CD20_CEREH } \\
\text { 2M }\end{array}$ & $\begin{array}{l}\text { Cervus elaphus hippelaphus } \\
\text { European red deer }\end{array}$ & $\begin{array}{c}32 \\
(24)\end{array}$ & 1469 \\
\hline
\end{tabular}


Table 2. Cont.

\begin{tabular}{|c|c|c|c|}
\hline $\begin{array}{c}\text { Protein ID } \\
\text { Protein Name }\end{array}$ & $\begin{array}{l}\text { Species Name } \\
\text { Common Name }\end{array}$ & $\begin{array}{c}\text { Matches } \\
\text { (Sequences) }\end{array}$ & $\begin{array}{l}\text { Total Score } \\
(p<0.05)^{+} \\
\end{array}$ \\
\hline A0A5N3XZ04_MUNRE & Muntiacus reevesi & 37 & \\
\hline IF rod domain-containing protein & Chinese muntjac & (25) & 1466 \\
\hline $\begin{array}{l}\text { A0A5N3WGH1_MUNMU } \\
\text { Uncharacterized protein (HRG) }\end{array}$ & $\begin{array}{l}\text { Muntiacus muntjac } \\
\text { Barking deer }\end{array}$ & $\begin{array}{l}142 \\
(87)\end{array}$ & 1393 \\
\hline $\begin{array}{c}\text { A0A6B0S2F2_9CETA } \\
\text { Fibrinogen C-terminal domain-containing protein }\end{array}$ & $\begin{array}{l}\text { Bos mutus } \\
\text { Wild yak }\end{array}$ & $\begin{array}{c}43 \\
(29)\end{array}$ & 1365 \\
\hline $\begin{array}{c}\text { A0A5N4DHW9_CAMDR } \\
\text { Keratin }\end{array}$ & $\begin{array}{l}\text { Camelus dromedarius } \\
\text { Dromedary }\end{array}$ & $\begin{array}{c}31 \\
(21)\end{array}$ & 1284 \\
\hline $\begin{array}{c}\text { *A0A212D8V0_CEREH } \\
\text { FGG }\end{array}$ & Cervus elaphus hippelaphus & $\begin{array}{l}47 \\
(34)\end{array}$ & 1235 \\
\hline $\begin{array}{l}\text { *A0A6J0YZJ7_ODOVR } \\
\text { Ceruloplasmin isoform X2 }\end{array}$ & $\begin{array}{l}\text { Odocoileus virginianus texanus } \\
\text { European red deer }\end{array}$ & $\begin{array}{c}28 \\
(16)\end{array}$ & 1227 \\
\hline $\begin{array}{l}\text { A0A5N3WB21_MUNMU } \\
\text { Fibrinogen alpha chain }\end{array}$ & $\begin{array}{l}\text { Muntiacus muntjac } \\
\text { Barking deer }\end{array}$ & $\begin{array}{c}42 \\
(24)\end{array}$ & 1207 \\
\hline $\begin{array}{c}\text { W5PF65_SHEEP } \\
\text { Beta-1 metal-binding globulin }\end{array}$ & $\begin{array}{l}\text { Ovis aries } \\
\text { Sheep }\end{array}$ & $\begin{array}{c}32 \\
(21)\end{array}$ & 1206 \\
\hline $\begin{array}{c}\text { A0A212CMY9_CEREH } \\
\text { Uncharacterized protein (immunoglobulin heavy constant mu; } \\
\text { beta-2-microglobulin) }\end{array}$ & $\begin{array}{l}\text { Cerous elaphus hippelaphus } \\
\text { European red deer }\end{array}$ & $\begin{array}{c}47 \\
(30)\end{array}$ & 1156 \\
\hline $\begin{array}{c}\text { A0A5N3XTY4_MUNRE } \\
\text { Uncharacterized protein (complement factor } H \text { ) }\end{array}$ & $\begin{array}{l}\text { Muntiacus reevesi } \\
\text { Chinese muntjac }\end{array}$ & $\begin{array}{c}26 \\
(21)\end{array}$ & 1151 \\
\hline $\begin{array}{l}\text { *A0A6J0XY06_ODOVR } \\
\text { Thrombospondin-1 isoform }\end{array}$ & $\begin{array}{l}\text { Odocoileus virginianus texanus } \\
\text { White-tailed deer }\end{array}$ & $\begin{array}{c}21 \\
(12)\end{array}$ & 1076 \\
\hline $\begin{array}{l}\text { *A0A6J0XUD5_ODOVR } \\
\text { Complement C4- } A \text {-like }\end{array}$ & $\begin{array}{c}\text { Odocoileus virginianus texanus } \\
\text { White-tailed deer }\end{array}$ & $\begin{array}{c}20 \\
(15)\end{array}$ & 1074 \\
\hline $\begin{array}{l}{ }^{\text {*A0A6J0WY92_ODOVR }} \\
\text { Complement factor H-like }\end{array}$ & $\begin{array}{l}\text { Odocoileus virginianus texanus } \\
\text { White-tailed deer }\end{array}$ & $\begin{array}{c}22 \\
(17)\end{array}$ & 1026 \\
\hline $\begin{array}{c}\text { *A0A6J0W0N0_ODOVR } \\
\text { Inter-alpha-trypsin inhibitor heavy chain H1 }\end{array}$ & $\begin{array}{c}\text { Odocoileus virginianus texanus } \\
\text { White-tailed deer }\end{array}$ & $\begin{array}{c}18 \\
(14)\end{array}$ & 944 \\
\hline $\begin{array}{c}\text { *A0A4W2C0F6_BOBOX } \\
\text { C4a anaphylatoxin }\end{array}$ & $\begin{array}{c}\text { Bos indicus } x \text { Bos taurus } \\
\text { Zebu } \times \text { Cow }\end{array}$ & $\begin{array}{c}16 \\
(11)\end{array}$ & 943 \\
\hline $\begin{array}{c}\text { *A0A212CJ19_CEREH } \\
C P\end{array}$ & $\begin{array}{l}\text { Cervus elaphus hippelaphus } \\
\text { European red deer }\end{array}$ & $\begin{array}{c}22 \\
(13)\end{array}$ & 935 \\
\hline $\begin{array}{l}\text { *A0A6J0XUP5_ODOVR } \\
\text { Complement C4-A-like }\end{array}$ & $\begin{array}{l}\text { Odocoileus virginianus texanus } \\
\text { White-tailed deer }\end{array}$ & $\begin{array}{c}15 \\
(12)\end{array}$ & 923 \\
\hline $\begin{array}{l}{ }^{*} \text { E1BH06_BOVIN } \\
\text { C4a anaphylatoxin }\end{array}$ & $\begin{array}{l}\text { Bos taurus } \\
\text { Cow }\end{array}$ & $\begin{array}{c}16 \\
(11)\end{array}$ & 921 \\
\hline $\begin{array}{c}\text { *A0A6J0WIC5_ODOVR } \\
\text { Inter-alpha-trypsin inhibitor heavy chain } \mathrm{H} 2\end{array}$ & $\begin{array}{l}\text { Odocoileus virginianus texanus } \\
\text { White-tailed deer }\end{array}$ & $\begin{array}{c}20 \\
(14)\end{array}$ & 879 \\
\hline $\begin{array}{c}\text { *A0A6J0YC26_ODOVR } \\
\text { Heparin cofactor } 2\end{array}$ & $\begin{array}{c}\text { Odocoileus virginianus texanus } \\
\text { White-tailed deer }\end{array}$ & $\begin{array}{c}17 \\
(11)\end{array}$ & 830 \\
\hline $\begin{array}{c}\text { A0A6I9IRH0_VICPA } \\
\text { Keratin, type I cytoskeletal } 14\end{array}$ & $\begin{array}{l}\text { Vicugna pacos } \\
\text { Alpaca }\end{array}$ & $\begin{array}{c}23 \\
(14)\end{array}$ & 822 \\
\hline $\begin{array}{l}\text { A0A287B5W2_PIG } \\
\text { Trypsinogen isoform X1 }\end{array}$ & $\begin{array}{l}\text { Sus scrofa } \\
\text { Wild boar }\end{array}$ & $\begin{array}{c}145 \\
(124)\end{array}$ & 795 \\
\hline $\begin{array}{c}\text { *A0A6J0ZDS1_ODOVR } \\
\text { C4b-binding protein alpha chain }\end{array}$ & $\begin{array}{c}\text { Odocoileus virginianus texanus } \\
\text { White-tailed deer }\end{array}$ & $\begin{array}{l}15 \\
(9)\end{array}$ & 783 \\
\hline
\end{tabular}


Table 2. Cont.

\begin{tabular}{|c|c|c|c|}
\hline $\begin{array}{c}\text { Protein ID } \\
\text { Protein Name }\end{array}$ & $\begin{array}{l}\text { Species Name } \\
\text { Common Name }\end{array}$ & $\begin{array}{c}\text { Matches } \\
\text { (Sequences) }\end{array}$ & $\begin{array}{l}\text { Total Score } \\
(p<0.05)^{\dagger}\end{array}$ \\
\hline $\begin{array}{c}\text { A0A6J0VYI5_ODOVR } \\
\text { Uncharacterized protein (complement C1q) }\end{array}$ & $\begin{array}{c}\text { Odocoileus virginianus texanus } \\
\text { White-tailed deer }\end{array}$ & $\begin{array}{c}19 \\
(14)\end{array}$ & 774 \\
\hline $\begin{array}{l}\text { A0A341C5T8_NEOAA } \\
\text { Serum albumin }\end{array}$ & $\begin{array}{l}\text { Neophocaena asiaeorientalis } \\
\text { asiaeorientalis } \\
\text { Narrow-ridged finless porpoise }\end{array}$ & $\begin{array}{c}31 \\
(11)\end{array}$ & 734 \\
\hline $\begin{array}{c}\text { A0A6J0YVR0_ODOVR } \\
\text { Keratin, type I cytoskeletal } 15 \text { isoform X1 }\end{array}$ & $\begin{array}{l}\text { Odocoileus virginianus texanus } \\
\text { White-tailed deer }\end{array}$ & $\begin{array}{c}20 \\
(13)\end{array}$ & 720 \\
\hline $\begin{array}{c}\text { A0A4W2D3K5_BOBOX } \\
\text { Keratin } 75\end{array}$ & $\begin{array}{c}\text { Bos indicus } x \text { Bos taurus } \\
\text { Zebu } \times \text { Cow }\end{array}$ & $\begin{array}{c}22 \\
(14)\end{array}$ & 716 \\
\hline $\begin{array}{c}\text { A0A287AEL2_PIG } \\
\text { IF rod domain-containing protein }\end{array}$ & $\begin{array}{l}\text { Sus scrofa } \\
\text { Wild boar }\end{array}$ & $\begin{array}{c}22 \\
(12)\end{array}$ & 708 \\
\hline $\begin{array}{c}\text { *A0A5N3XTJ5_MUNRE } \\
\text { Antithrombin-III }\end{array}$ & $\begin{array}{l}\text { Muntiacus reevesi } \\
\text { Chinese muntjac }\end{array}$ & $\begin{array}{l}14 \\
(4)\end{array}$ & 614 \\
\hline $\begin{array}{c}\text { *A0A220IGA4_RANTA } \\
\text { Adult beta-globin }\end{array}$ & $\begin{array}{l}\text { Rangifer tarandus } \\
\text { Reindeer }\end{array}$ & $\begin{array}{c}12 \\
(11)\end{array}$ & 603 \\
\hline $\begin{array}{c}\text { A0A212CMB3_CEREH } \\
\text { Uncharacterized protein (Ig gamma-3 chain C region; IgG } \\
\text { heavy chain) }\end{array}$ & $\begin{array}{l}\text { Cervus elaphus hippelaphus } \\
\text { European red deer }\end{array}$ & $\begin{array}{c}20 \\
(15)\end{array}$ & 593 \\
\hline $\begin{array}{c}\text { *A0A6J0WIA8_ODOVR } \\
\text { Prothrombin }\end{array}$ & $\begin{array}{c}\text { Odocoileus virginianus texanus } \\
\text { White-tailed deer }\end{array}$ & $\begin{array}{l}12 \\
(8)\end{array}$ & 567 \\
\hline $\begin{array}{c}\text { A0A6I9I3P0_VICPA } \\
\text { Keratin, type II cytoskeletal 5-like }\end{array}$ & $\begin{array}{l}\text { Vicugna pacos } \\
\text { Alpaca }\end{array}$ & $\begin{array}{l}16 \\
(9)\end{array}$ & 563 \\
\hline $\begin{array}{c}\text { *A0A6J0Y9J4_ODOVR } \\
\text { Apolipoprotein A-I }\end{array}$ & $\begin{array}{c}\text { Odocoileus virginianus texanus } \\
\text { White-tailed deer }\end{array}$ & $\begin{array}{l}10 \\
(7)\end{array}$ & 543 \\
\hline $\begin{array}{c}{ }^{*} \mathbf{Q} 9 \text { TS85_BOVIN } \\
\text { Histidine-rich GLYCOPROTEIN=FACTOR XIIIA substrate }\end{array}$ & $\begin{array}{l}\text { Bos taurus } \\
\text { Cow }\end{array}$ & $\begin{array}{c}39 \\
(18)\end{array}$ & 536 \\
\hline $\begin{array}{l}\text { *A0A212DHP9_CEREH } \\
\text { APOA1 }\end{array}$ & $\begin{array}{l}\text { Cervus elaphus hippelaphus } \\
\text { European red deer }\end{array}$ & $\begin{array}{c}9 \\
(7)\end{array}$ & 504 \\
\hline $\begin{array}{c}\text { *A0A0B8RTA2_PIG } \\
\text { Actin, gamma } 1\end{array}$ & $\begin{array}{l}\text { Sus scrofa } \\
\text { Wild boar }\end{array}$ & $\begin{array}{l}10 \\
(6)\end{array}$ & 502 \\
\hline $\begin{array}{l}\text { *A0A212D467_CEREH } \\
C 1 Q B\end{array}$ & $\begin{array}{l}\text { Cervus elaphus hippelaphus } \\
\text { European red deer }\end{array}$ & $\begin{array}{l}13 \\
(9)\end{array}$ & 498 \\
\hline $\begin{array}{l}\text { A0A2Y9SJP9_PHYMC } \\
\text { Keratin, type II cytoskeletal }\end{array}$ & $\begin{array}{l}\text { Physeter macrocephalus } \\
\text { Sperm whale }\end{array}$ & $\begin{array}{l}14 \\
(7)\end{array}$ & 495 \\
\hline $\begin{array}{l}\text { *A0A5N3VLU1_MUNMU } \\
\text { Prothrombin }\end{array}$ & $\begin{array}{l}\text { Muntiacus muntjac } \\
\text { Barking deer }\end{array}$ & $\begin{array}{l}11 \\
(6)\end{array}$ & 482 \\
\hline $\begin{array}{c}\text { HRG_BOVIN } \\
\text { Histidine-rich glycoprotein }\end{array}$ & $\begin{array}{l}\text { Bos taurus } \\
\text { Cow }\end{array}$ & $\begin{array}{c}21 \\
(14)\end{array}$ & 480 \\
\hline $\begin{array}{l}\text { *S9Y253_CAMFR } \\
\text { Kininogen-2 isoform I }\end{array}$ & $\begin{array}{c}\text { Camelus ferus } \\
\text { Wild Bactrian camel }\end{array}$ & $\begin{array}{c}28 \\
(11)\end{array}$ & 451 \\
\hline $\begin{array}{c}\text { *A0A6J0XQV8_ODOVR } \\
\text { Hemopexin }\end{array}$ & $\begin{array}{c}\text { Odocoileus virginianus texanus } \\
\text { White-tailed deer }\end{array}$ & $\begin{array}{c}9 \\
(5)\end{array}$ & 450 \\
\hline $\begin{array}{l}\text { *A0A6J0WWF4_ODOVR } \\
\text { Vitronectin isoform X1 }\end{array}$ & $\begin{array}{l}\text { Odocoileus virginianus texanus } \\
\text { White-tailed deer }\end{array}$ & $\begin{array}{l}10 \\
(7)\end{array}$ & 438 \\
\hline $\begin{array}{l}\text { *A0A6J0W8S2_ODOVR } \\
\text { Plasminogen isoform X1 }\end{array}$ & $\begin{array}{l}\text { Odocoileus virginianus texanus } \\
\text { White-tailed deer }\end{array}$ & $\begin{array}{l}11 \\
(3)\end{array}$ & 434 \\
\hline $\begin{array}{c}\text { A0A5J5MM15_MUNRE } \\
\text { Uncharacterized protein (immunoglobulin kappa light chain-like) }\end{array}$ & $\begin{array}{l}\text { Muntiacus reevesi } \\
\text { Chinese muntjac }\end{array}$ & $\begin{array}{l}12 \\
(7)\end{array}$ & 425 \\
\hline $\begin{array}{l}\text { *A0A6J0Z5Q2_ODOVR } \\
\text { Transcobalamin-2 }\end{array}$ & $\begin{array}{l}\text { Odocoileus virginianus texanus } \\
\text { White-tailed deer }\end{array}$ & $\begin{array}{l}8 \\
(6)\end{array}$ & 423 \\
\hline $\begin{array}{c}\text { *A0A5N3X8Z5_MUNRE } \\
\text { Hemopexin }\end{array}$ & $\begin{array}{l}\text { Muntiacus reevesi } \\
\text { Reeves's muntjac }\end{array}$ & $\begin{array}{c}7 \\
(5)\end{array}$ & 422 \\
\hline
\end{tabular}


Table 2. Cont.

\begin{tabular}{|c|c|c|c|}
\hline $\begin{array}{l}\text { Protein ID } \\
\text { Protein Name }\end{array}$ & $\begin{array}{l}\text { Species Name } \\
\text { Common Name }\end{array}$ & $\begin{array}{c}\text { Matches } \\
\text { (Sequences) }\end{array}$ & $\begin{array}{l}\text { Total Score } \\
(p<0.05)^{+}\end{array}$ \\
\hline *A0A212CJF4_CEREH & Cervus elaphus hippelaphus & 17 & \multirow{2}{*}{415} \\
\hline C1q domain-containing protein & European red deer & $(10)$ & \\
\hline *C0LXP2_ODOVR & Odocoileus virginianus texanus & 6 & \multirow{2}{*}{408} \\
\hline Complement 1 subcomponent q polypeptide gamma & White-tailed deer & $(5)$ & \\
\hline A0A5N3W8P2_MUNMU & Muntiacus muntjac & 11 & \multirow{2}{*}{398} \\
\hline Uncharacterized protein (Ig-like domain-containing protein) & Barking deer & (9) & \\
\hline *A0A286ZIC1_PIG & & & \multirow[b]{2}{*}{371} \\
\hline Actin-depolymerizing factor & Wils boar & $\begin{array}{c}8 \\
(3)\end{array}$ & \\
\hline *A0A5N3VK90_MUNMU & Muntiacus muntjac & 7 & \multirow{2}{*}{369} \\
\hline Actin-depolymerizing factor & Barking deer & $(3)$ & \\
\hline A0A212DB90_CEREH & Cervus elaphus hippelaphus & 9 & \multirow{2}{*}{364} \\
\hline Ig-like domain-containing protein & European red deer & (5) & \\
\hline *A0A212DHZ3_CEREH & Cervus elaphus hippelaphus & 7 & \multirow{2}{*}{349} \\
\hline$H P X$ & European red deer & (4) & \\
\hline *A0A6J0X6J4_ODOVR & Odocoileus virginianus texanus & 9 & \multirow{2}{*}{334} \\
\hline Selenoprotein $P$ & White-tailed deer & (5) & \\
\hline *A0A6J0Y2T5_ODOVR & Odocoileus virginianus texanus & 7 & \multirow{2}{*}{333} \\
\hline Hemoglobin subunit alpha & White-tailed deer & (3) & \\
\hline *A0A480Y2E3_PIG & Sus scrofa & 16 & \multirow{2}{*}{333} \\
\hline Kininogen-1 isoform 1 & Wild boar & (5) & \\
\hline *A0A6J0YKX8_ODOVR & Odocoileus virginianus texanus & 6 & \multirow{2}{*}{324} \\
\hline Protein $A M B P$ & White-tailed deer & (5) & \\
\hline A0A4W2DA54_BOBOX & Bos indicus $x$ Bos taurus & 4 & \multirow[b]{2}{*}{314} \\
\hline $\begin{array}{l}\text { Uncharacterized protein } \\
\text { (Heparan sulfate proteoglycan 2) }\end{array}$ & Zebu x Cow & (3) & \\
\hline *A0A5J5MM09_MUNRE & Muntiacus reevesi & 9 & \multirow{2}{*}{308} \\
\hline Plasminogen & Chinese muntjac & (2) & \\
\hline *A0A212C7P2_CEREH & Cerous elaphus hippelaphus & 8 & \multirow{2}{*}{299} \\
\hline$P L G$ & European red deer & $(2)$ & \\
\hline *A0A5N3WQN5_MUNMU & Muntiacus muntjac & 8 & \multirow{2}{*}{278} \\
\hline Vitellogenin domain-containing protein & Barking deer & (1) & \\
\hline *A0A5N3X9D4_MUNRE & Muntiacus reevesi & 6 & \multirow{2}{*}{270} \\
\hline SERPIN domain-containing protein & Chinese muntjac & (4) & \\
\hline *A0A6J0YIK3_ODOVR & Odocoileus virginianus texanus & 5 & \multirow{2}{*}{267} \\
\hline Vitamin D-binding protein & White-tailed deer & (4) & \\
\hline *A0A6J0XXC2_ODOVR & Odocoileus virginianus texanus & 7 & \multirow[b]{2}{*}{267} \\
\hline Apolipoprotein B-100 isoform X1 & White-tailed deer & (1) & \\
\hline${ }^{*}$ A0A6J0Y0A8_ODOVR & Odocoileus virginianus texanus & 6 & \multirow{2}{*}{267} \\
\hline Serpin A3-7-like & White-tailed deer & $(4)$ & \\
\hline *A0A212CS37_CEREH & Cervus elaphus hippelaphus & 6 & \multirow{2}{*}{265} \\
\hline SERPIN domain-containing protein & European red deer & $(4)$ & \\
\hline A0A5N3XX47_MUNRE & Muntiacus reevesi & 5 & \multirow[b]{2}{*}{259} \\
\hline $\begin{array}{c}\text { Uncharacterized protein (inter-alpha-trypsin inhibitor heavy chain } \\
\text { H4) }\end{array}$ & Chinese muntjac & $(3)$ & \\
\hline *A0A6J0VV77_ODOVR & Odocoileus virginianus texanus & 5 & 255 \\
\hline CD5 antigen-like & White-tailed deer & (3) & 255 \\
\hline *A0A5N3WVG9_MUNMU & Muntiacus reevesi & 4 & \\
\hline Apolipoprotein $\mathrm{H}$ & Chinese muntjac & (3) & 252 \\
\hline A0A4W2E1T0_BOBOX & & & \\
\hline Uncharacterized protein & Bos indicus $x$ Bos taurus & 5 & \\
\hline $\begin{array}{l}\text { (FZ domain-containing protein; collagen type XVIII alpha } 1 \text { chain; } \\
\text { COL18A1 protein) }\end{array}$ & Zebu $\times$ Cow & (3) & 244 \\
\hline A0A2Y9N2V9_DELLE & Delphinapterus leucas & 19 & \\
\hline Bradykinin & Beluga whale & (5) & 235 \\
\hline
\end{tabular}


Table 2. Cont

\begin{tabular}{|c|c|c|c|}
\hline $\begin{array}{l}\text { Protein ID } \\
\text { Protein Name }\end{array}$ & $\begin{array}{l}\text { Species Name } \\
\text { Common Name }\end{array}$ & $\begin{array}{c}\text { Matches } \\
\text { (Sequences) }\end{array}$ & $\begin{array}{l}\text { Total Score } \\
(p<0.05)^{+}\end{array}$ \\
\hline $\begin{array}{c}\text { *A0A212D5I5_CEREH } \\
D S P \\
\end{array}$ & $\begin{array}{l}\text { Cervus elaphus hippelaphus } \\
\text { European red deer }\end{array}$ & $\begin{array}{c}6 \\
(1)\end{array}$ & 207 \\
\hline $\begin{array}{c}\text { A0A4U1EJD5_MONMO } \\
\text { TAF domain-containing protein }\end{array}$ & $\begin{array}{l}\text { Monodon monoceros } \\
\text { Narwhale }\end{array}$ & $\begin{array}{c}5 \\
(3)\end{array}$ & 204 \\
\hline $\begin{array}{c}\text { *A0A6B0SDR2_9CETA } \\
\text { Glyceraldehyde-3-phosphate dehydrogenase }\end{array}$ & $\begin{array}{l}\text { Bos mutus } \\
\text { Wild yak }\end{array}$ & $\begin{array}{c}6 \\
(2)\end{array}$ & 202 \\
\hline $\begin{array}{c}\text { *A0A5N3V0U6_MUNMU } \\
\text { Peptidase_M14 domain-containing protein }\end{array}$ & $\begin{array}{l}\text { Muntiacus muntjac } \\
\text { Barking deer }\end{array}$ & $\begin{array}{c}5 \\
(1)\end{array}$ & 200 \\
\hline $\begin{array}{c}\text { A0A5N3VBS8_MUNMU } \\
\text { Uncharacterized protein (insulin-like growth factor-binding protein } \\
\text { complex acid labile subunit) }\end{array}$ & $\begin{array}{l}\text { Muntiacus muntjac } \\
\text { Barking deer }\end{array}$ & $\begin{array}{l}4 \\
(2)\end{array}$ & 199 \\
\hline $\begin{array}{c}\text { A0A287AAL6_PIG } \\
\begin{array}{c}\text { Uncharacterized protein (four and a half LIM domains protein } 1 \\
\text { isoform X3) }\end{array}\end{array}$ & $\begin{array}{l}\text { Sus scrofa } \\
\text { Wild boar }\end{array}$ & $\begin{array}{c}4 \\
(2)\end{array}$ & 198 \\
\hline $\begin{array}{l}\text { *A0A2U4C7Y7_TURTR } \\
\text { Histidine-rich glycoprotein }\end{array}$ & $\begin{array}{c}\text { Tursiops truncates } \\
\text { Common bottlenose dolphin }\end{array}$ & $\begin{array}{l}24 \\
(2)\end{array}$ & 186 \\
\hline $\begin{array}{c}\text { A0A3Q1M1M7_BOVIN } \\
\text { Junction plakoglobin }\end{array}$ & $\begin{array}{l}\text { Bos taurus } \\
\text { Cow }\end{array}$ & $\begin{array}{c}4 \\
(3) \\
\end{array}$ & 186 \\
\hline $\begin{array}{c}\text { A0A212CSZ9_CEREH } \\
\text { Ig-like domain-containing protein }\end{array}$ & $\begin{array}{l}\text { Cervus elaphus hippelaphus } \\
\text { European red deer }\end{array}$ & $\begin{array}{c}3 \\
(1)\end{array}$ & 181 \\
\hline $\begin{array}{c}\text { *A0A452FXZ3_CAPHI } \\
\text { Apolipoprotein } H\end{array}$ & $\begin{array}{l}\text { Capra hircus } \\
\text { Goat }\end{array}$ & $\begin{array}{c}3 \\
(2)\end{array}$ & 180 \\
\hline $\begin{array}{c}\text { *A0A5N3WZL8_MUNMU } \\
\text { Complement C1q subcomponent subunit A }\end{array}$ & $\begin{array}{l}\text { Muntiacus muntjac } \\
\text { Barking deer }\end{array}$ & $\begin{array}{c}4 \\
(3)\end{array}$ & 179 \\
\hline $\begin{array}{c}\text { *A0A6J0XZP9_ODOVR } \\
\text { Alpha-1-antitrypsin }\end{array}$ & Odocoileus virginianus texanus & $\begin{array}{c}5 \\
(2)\end{array}$ & 179 \\
\hline $\begin{array}{l}\text { *A0A452E7A0_CAPHI } \\
\text { Plasminogen }\end{array}$ & $\begin{array}{l}\text { Capra hircus } \\
\text { Goat }\end{array}$ & $\begin{array}{c}5 \\
(2)\end{array}$ & 176 \\
\hline $\begin{array}{l}\text { A0A4V5P683_MONMO } \\
\text { Uncharacterized protein } \\
\text { (histone H2B type 1-L-like) }\end{array}$ & $\begin{array}{l}\text { Monodon monoceros } \\
\text { Narwhale }\end{array}$ & $\begin{array}{c}4 \\
(2)\end{array}$ & 174 \\
\hline $\begin{array}{l}\text { A0A6B9SCH7_BOVIN } \\
\text { Ig lamda chain variable region }\end{array}$ & $\begin{array}{l}\text { Bos taurus } \\
\text { Cow }\end{array}$ & $\begin{array}{c}2 \\
(2)\end{array}$ & 160 \\
\hline $\begin{array}{c}\text { A0A452E8D3_CAPHI } \\
\text { Ig-like domain-containing protein }\end{array}$ & $\begin{array}{l}\text { Capra hircus } \\
\text { Goat }\end{array}$ & $\begin{array}{c}3 \\
(2)\end{array}$ & 157 \\
\hline $\begin{array}{c}\text { *A0A452F014_CAPHI } \\
\text { SERPIN domain-containing protein }\end{array}$ & $\begin{array}{l}\text { Capra hircus } \\
\text { Goat }\end{array}$ & $\begin{array}{c}4 \\
(1)\end{array}$ & 155 \\
\hline $\begin{array}{c}\text { *A0A2Y9LVH2_DELLE } \\
\text { Amine oxidase }\end{array}$ & $\begin{array}{l}\text { Delphinapterus leucas } \\
\text { Beluga whale }\end{array}$ & $\begin{array}{c}2 \\
(2)\end{array}$ & 141 \\
\hline $\begin{array}{c}\text { A0A6B0SAT2_9CETA } \\
\text { Ig-like domain-containing protein }\end{array}$ & $\begin{array}{l}\text { Bos mutus } \\
\text { Wild yak }\end{array}$ & $\begin{array}{c}4 \\
(1) \\
\end{array}$ & 140 \\
\hline $\begin{array}{c}\text { A0A4W2CFX9_BOBOX } \\
\text { Ig-like domain-containing protein }\end{array}$ & $\begin{array}{c}\text { Bos indicus } x \text { Bos taurus } \\
\text { Zebu } \times \text { Cow }\end{array}$ & $\begin{array}{c}2 \\
(1)\end{array}$ & 139 \\
\hline $\begin{array}{c}\text { A2P2I1_SHEEP } \\
\text { VH region }\end{array}$ & $\begin{array}{l}\text { Ovis aries } \\
\text { Sheep }\end{array}$ & $\begin{array}{c}2 \\
(1)\end{array}$ & 139 \\
\hline $\begin{array}{c}\text { *A0A088Q0F1_9CETA } \\
\text { Heat shock protein 90kDa alpha }\end{array}$ & $\begin{array}{l}\text { Bos grunniens } x \text { Bos taurus } \\
\text { Domestic yak } x \text { Cow }\end{array}$ & $\begin{array}{c}2 \\
(2)\end{array}$ & 137 \\
\hline $\begin{array}{c}\text { A0A5N3UK72_MUNRE } \\
\text { Ig-like domain-containing protein }\end{array}$ & $\begin{array}{l}\text { Muntiacus reevesi } \\
\text { Chinese muntjac }\end{array}$ & $\begin{array}{c}2 \\
(1)\end{array}$ & 133 \\
\hline
\end{tabular}


Table 2. Cont.

\begin{tabular}{|c|c|c|c|}
\hline $\begin{array}{c}\text { Protein ID } \\
\text { Protein Name }\end{array}$ & $\begin{array}{l}\text { Species Name } \\
\text { Common Name }\end{array}$ & $\begin{array}{c}\text { Matches } \\
\text { (Sequences) }\end{array}$ & $\begin{array}{l}\text { Total Score } \\
(p<0.05)^{\dagger}\end{array}$ \\
\hline $\begin{array}{l}\text { FIBA_ALCAA } \\
\text { Fibrinogen alpha chain }\end{array}$ & $\begin{array}{l}\text { Alces alces alces } \\
\text { Moose }\end{array}$ & $\begin{array}{c}1 \\
(1)\end{array}$ & 122 \\
\hline $\begin{array}{c}\text { A0A643C7L4_BALPH } \\
\text { Uncharacterized protein (desmoplakin) }\end{array}$ & $\begin{array}{l}\text { Balaenoptera physalus } \\
\text { Fin whale }\end{array}$ & $\begin{array}{c}4 \\
(1)\end{array}$ & 120 \\
\hline $\begin{array}{c}\text { A6QM09_BOVIN } \\
\text { Uncharacterized protein (Ig-like domain-containing protein; Ig } \\
\text { lambda chain V-III region LOI-like protein) }\end{array}$ & $\begin{array}{l}\text { Bos taurus } \\
\text { Cow }\end{array}$ & $\begin{array}{c}4 \\
(1)\end{array}$ & 118 \\
\hline $\begin{array}{c}\text { *A0A6B0R457_9CETA } \\
\text { Activating signal cointegrator } 1 \text { complex subunit } 3\end{array}$ & $\begin{array}{l}\text { Bos mutus } \\
\text { Wild yak }\end{array}$ & $\begin{array}{c}3 \\
(1)\end{array}$ & 118 \\
\hline $\begin{array}{c}\text { *A0A212DB97_CEREH } \\
\text { SERPINF2 }\end{array}$ & $\begin{array}{l}\text { Cervus elaphus hippelaphus } \\
\text { European red deer }\end{array}$ & $\begin{array}{c}2 \\
(1)\end{array}$ & 117 \\
\hline $\begin{array}{c}\text { *A0A6J3PT56_TURTR } \\
\text { Immunoglobulin lambda-1 light chain-like isoform X1 }\end{array}$ & $\begin{array}{c}\text { Tursiops truncates } \\
\text { Common bottlenose dolphin }\end{array}$ & $\begin{array}{c}4 \\
(1)\end{array}$ & 116 \\
\hline $\begin{array}{c}\text { A0A3Q1LT19_BOVIN } \\
\text { Ig-like domain-containing protein }\end{array}$ & $\begin{array}{l}\text { Bos taurus } \\
\text { Cow }\end{array}$ & $\begin{array}{c}2 \\
(2)\end{array}$ & 113 \\
\hline $\begin{array}{l}\text { *A0A212CSZ1_CEREH } \\
\text { SERPINA5 }\end{array}$ & $\begin{array}{l}\text { Cervus elaphus hippelaphus } \\
\text { European red deer }\end{array}$ & $\begin{array}{c}3 \\
(1)\end{array}$ & 112 \\
\hline $\begin{array}{c}\text { A0A5N4CT25_CAMDR } \\
\text { Histone H4 }\end{array}$ & $\begin{array}{l}\text { Camelus dromedarius } \\
\text { Dromedary }\end{array}$ & $\begin{array}{c}3 \\
(1)\end{array}$ & 107 \\
\hline $\begin{array}{l}\text { *A0A6J0XAN1_ODOVR } \\
\text { Complement component C9 }\end{array}$ & $\begin{array}{l}\text { Odocoileus virginianus texanus } \\
\text { White-tailed deer }\end{array}$ & $\begin{array}{c}3 \\
(1)\end{array}$ & 104 \\
\hline $\begin{array}{c}\text { *A0A6J0Y2I3_ODOVR } \\
\text { Alpha-1B-glycoprotein }\end{array}$ & $\begin{array}{l}\text { Odocoileus virginianus texanus } \\
\text { White-tailed deer }\end{array}$ & $\begin{array}{c}2 \\
(1)\end{array}$ & 95 \\
\hline $\begin{array}{l}\text { A0A2F0AYU0_ESCRO } \\
\text { Ig lambda chain V-III region } S H\end{array}$ & $\begin{array}{l}\text { Eschrichtius robustus } \\
\text { Gray whale }\end{array}$ & $\begin{array}{c}2 \\
(1)\end{array}$ & 95 \\
\hline $\begin{array}{c}\text { A0A212CS30_CEREH } \\
\text { Ig-like domain-containing protein }\end{array}$ & $\begin{array}{l}\text { Cervus elaphus hippelaphus } \\
\text { European red deer }\end{array}$ & $\begin{array}{c}2 \\
(1)\end{array}$ & 93 \\
\hline $\begin{array}{c}\text { *A0A1L6BNZ0_BUBBU } \\
\text { Alpha-S1-casein }\end{array}$ & $\begin{array}{l}\text { Bubalus bubalis } \\
\text { Water buffalo }\end{array}$ & $\begin{array}{c}2 \\
(1)\end{array}$ & 93 \\
\hline $\begin{array}{l}\text { *A0A212D4C7_CEREH } \\
\text { Ribosomal protein }\end{array}$ & $\begin{array}{l}\text { Cervus elaphus hippelaphus } \\
\text { European red deer }\end{array}$ & $\begin{array}{c}1 \\
(1)\end{array}$ & 92 \\
\hline $\begin{array}{c}\text { *A0A212CIC4_CEREH } \\
\text { FETUB }\end{array}$ & $\begin{array}{l}\text { Cervus elaphus hippelaphus } \\
\text { European red deer }\end{array}$ & $\begin{array}{c}2 \\
(1)\end{array}$ & 91 \\
\hline $\begin{array}{l}\text { A0A0R4I993_SUSBA } \\
\text { Tubulin alpha chain }\end{array}$ & $\begin{array}{c}\text { Sus barbatus } \\
\text { Bornean bearded pig }\end{array}$ & $\begin{array}{c}2 \\
(1)\end{array}$ & 89 \\
\hline $\begin{array}{c}\text { A2P2I3_SHEEP } \\
\text { VH region }\end{array}$ & $\begin{array}{l}\text { Ovis aries } \\
\text { Sheep }\end{array}$ & $\begin{array}{c}2 \\
(1)\end{array}$ & 89 \\
\hline $\begin{array}{c}\text { *A0A6J0WSX6_ODOVR } \\
\text { Tubulin beta-3 chain }\end{array}$ & $\begin{array}{c}\text { Odocoileus virginianus texanus } \\
\text { White-tailed deer }\end{array}$ & $\begin{array}{c}2 \\
(1)\end{array}$ & 88 \\
\hline $\begin{array}{c}\text { *A0A340WKS1_LIPVE } \\
\text { Selenoprotein } P\end{array}$ & $\begin{array}{c}\text { Lipotes vexillifer } \\
\text { Baiji }\end{array}$ & $\begin{array}{l}3 \\
(1)\end{array}$ & 87 \\
\hline $\begin{array}{c}\text { *A0A4W2BXS4_BOBOX } \\
\text { Kallikrein B1 }\end{array}$ & $\begin{array}{c}\text { Bos indicus } x \text { Bos taurus } \\
\text { Zebu } \times \text { Cow }\end{array}$ & $\begin{array}{c}2 \\
(1)\end{array}$ & 86 \\
\hline $\begin{array}{c}\text { R4R2H5_SHEEP } \\
\text { Beta-casein }\end{array}$ & $\begin{array}{l}\text { Ovis aries } \\
\text { Sheep }\end{array}$ & $\begin{array}{c}2 \\
(1)\end{array}$ & 84 \\
\hline $\begin{array}{c}\text { *A0A6J0Z7P6_ODOVR } \\
\text { Apolipoprotein R-like }\end{array}$ & $\begin{array}{c}\text { Odocoileus virginianus texanus } \\
\text { White-tailed deer }\end{array}$ & $\begin{array}{c}2 \\
(1)\end{array}$ & 84 \\
\hline
\end{tabular}


Table 2. Cont.

\begin{tabular}{|c|c|c|c|}
\hline $\begin{array}{c}\text { Protein ID } \\
\text { Protein Name }\end{array}$ & $\begin{array}{l}\text { Species Name } \\
\text { Common Name }\end{array}$ & $\begin{array}{c}\text { Matches } \\
\text { (Sequences) }\end{array}$ & $\begin{array}{l}\text { Total Score } \\
(p<0.05)^{+} \\
\end{array}$ \\
\hline $\begin{array}{c}\text { A0A6B9SDT6_BOVIN } \\
\text { Ig lamda chain variable region }\end{array}$ & $\begin{array}{l}\text { Bos taurus } \\
\text { Cow }\end{array}$ & $\begin{array}{c}1 \\
(1)\end{array}$ & 84 \\
\hline $\begin{array}{l}\text { *A0A5N3WWG2_MUNMU } \\
\text { SERPIN domain-containing protein }\end{array}$ & $\begin{array}{l}\text { Muntiacus muntjac } \\
\text { Barking deer }\end{array}$ & $\begin{array}{c}2 \\
(1)\end{array}$ & 83 \\
\hline $\begin{array}{c}\text { *A0A2Y9EXF5_PHYMC } \\
\text { 2-phospho-D-glycerate hydro-lyase }\end{array}$ & $\begin{array}{l}\text { Physeter macrocephalus } \\
\text { Sperm whale }\end{array}$ & $\begin{array}{c}1 \\
(1)\end{array}$ & 82 \\
\hline $\begin{array}{c}\text { *A0A212D4I5_CEREH } \\
\text { C3/C5 convertase }\end{array}$ & $\begin{array}{l}\text { Cervus elaphus hippelaphus } \\
\text { European red deer }\end{array}$ & $\begin{array}{c}3 \\
(1)\end{array}$ & 81 \\
\hline $\begin{array}{l}\text { *A0A212CM12_CEREH } \\
\text { 40S ribosomal protein S18 }\end{array}$ & $\begin{array}{l}\text { Cervus elaphus hippelaphus } \\
\text { European red deer }\end{array}$ & $\begin{array}{c}1 \\
(1)\end{array}$ & 80 \\
\hline $\begin{array}{c}\text { A0A452G1G8_CAPHI } \\
\text { Uncharacterized protein }(m s x 2 \text {-interacting protein isoform } X, X 2, \\
X 3, X 4)\end{array}$ & $\begin{array}{l}\text { Capra hircus } \\
\text { Goat }\end{array}$ & $\begin{array}{c}3 \\
(1)\end{array}$ & 79 \\
\hline $\begin{array}{l}\text { A0A212CAL2_CEREH } \\
\text { Elongation factor 1-alpha }\end{array}$ & $\begin{array}{l}\text { Cervus elaphus hippelaphus } \\
\text { European red deer }\end{array}$ & $\begin{array}{c}2 \\
(2)\end{array}$ & 79 \\
\hline $\begin{array}{l}\text { *A0A212CI11_CEREH } \\
\text { Alpha-2-HS-glycoprotein }\end{array}$ & $\begin{array}{l}\text { Cervus elaphus hippelaphus } \\
\text { European red deer }\end{array}$ & $\begin{array}{c}1 \\
(1)\end{array}$ & 78 \\
\hline $\begin{array}{c}\text { A0A2F0B9E6_ESCRO } \\
\text { Trypsin }\end{array}$ & $\begin{array}{l}\text { Eschrichtius robustus } \\
\text { Gray whale }\end{array}$ & $\begin{array}{c}5 \\
(2)\end{array}$ & 78 \\
\hline $\begin{array}{c}\text { *A0A5J5MZJ4_MUNRE } \\
M A C P F \text { domain-containing protein }\end{array}$ & $\begin{array}{l}\text { Muntiacus reevesi } \\
\text { Chinese muntjac }\end{array}$ & $\begin{array}{c}2 \\
(1)\end{array}$ & 74 \\
\hline $\begin{array}{c}\text { *A0A212C6Y8_CEREH } \\
\text { Transthyretin }\end{array}$ & $\begin{array}{l}\text { Cervus elaphus hippelaphus } \\
\text { European red deer }\end{array}$ & $\begin{array}{c}1 \\
(1)\end{array}$ & 73 \\
\hline $\begin{array}{c}\text { *A0A212D5R7_CEREH } \\
\text { JCHAIN }\end{array}$ & $\begin{array}{l}\text { Cervus elaphus hippelaphus } \\
\text { European red deer }\end{array}$ & $\begin{array}{c}2 \\
(1)\end{array}$ & 73 \\
\hline $\begin{array}{c}\text { *A0A480MMJ7_PIG } \\
\text { Heat shock } 70 \mathrm{kDa} \text { protein }\end{array}$ & $\begin{array}{l}\text { Sus scrofa } \\
\text { Wild boar }\end{array}$ & $\begin{array}{c}2 \\
(2)\end{array}$ & 72 \\
\hline $\begin{array}{c}\text { *A0A6J0Y8N1_ODOVR } \\
\text { Angiopoietin-related protein } 6 \text { isoform X2 }\end{array}$ & $\begin{array}{l}\text { Odocoileus virginianus texanus } \\
\text { White-tailed deer }\end{array}$ & $\begin{array}{c}2 \\
(1)\end{array}$ & 72 \\
\hline $\begin{array}{c}\text { *A0A5N4EH44_CAMDR } \\
\text { Biorientation of chromosomes in cell division protein 1-like } 1\end{array}$ & $\begin{array}{l}\text { Camelus dromedarius } \\
\text { Dromedary }\end{array}$ & $\begin{array}{c}2 \\
(1)\end{array}$ & 71 \\
\hline $\begin{array}{c}\text { *S9WER1_CAMFR } \\
\text { Biorientation of chromosomes in cell division protein 1-like protein }\end{array}$ & $\begin{array}{c}\text { Camelus ferus } \\
\text { Wild Bactrian camel }\end{array}$ & $\begin{array}{c}2 \\
(1)\end{array}$ & 71 \\
\hline $\begin{array}{c}\text { A0A212D1P2_CEREH } \\
\text { Uncharacterized protein (N-acetylmuramoyl-L-alanine amidase) }\end{array}$ & $\begin{array}{l}\text { Cervus elaphus hippelaphus } \\
\text { European red deer }\end{array}$ & $\begin{array}{c}2 \\
(1)\end{array}$ & 70 \\
\hline $\begin{array}{c}\text { *A0A3Q1LUP1_BOVIN } \\
\text { Uncharacterized protein (cilia-and flagella-associated protein } 54 \text { ) }\end{array}$ & $\begin{array}{l}\text { Bos taurus } \\
\text { Cow }\end{array}$ & $\begin{array}{c}3 \\
(1)\end{array}$ & 69 \\
\hline $\begin{array}{c}\text { A0A212CM59_CEREH } \\
\text { Ig-like domain-containing protein }\end{array}$ & $\begin{array}{l}\text { Cervus elaphus hippelaphus } \\
\text { European red deer }\end{array}$ & $\begin{array}{c}4 \\
(1)\end{array}$ & 68 \\
\hline $\begin{array}{l}\text { *A0A2Y9EUI8_PHYMC } \\
\text { Arachidonate 15-lipoxygenase }\end{array}$ & $\begin{array}{l}\text { Physeter macrocephalus } \\
\text { Sperm whale }\end{array}$ & $\begin{array}{c}3 \\
(1)\end{array}$ & 67 \\
\hline $\begin{array}{l}\text { A2P2H1_SHEEP } \\
\text { VH region }\end{array}$ & $\begin{array}{l}\text { Ovis aries } \\
\text { Sheep }\end{array}$ & $\begin{array}{c}2 \\
(1)\end{array}$ & 66 \\
\hline $\begin{array}{c}\text { *A0A0B8RZA9_PIG } \\
\text { Proliferation-associated 2G4, 38kDa) }\end{array}$ & $\begin{array}{l}\text { Sus scrofa } \\
\text { Wild boar }\end{array}$ & $\begin{array}{c}2 \\
(2)\end{array}$ & 66 \\
\hline $\begin{array}{c}\text { A0A4X1TXJ2_PIG } \\
\text { Uncharacterized protein (IgG heavy chian constant region) }\end{array}$ & $\begin{array}{l}\text { Sus scrofa } \\
\text { Wild boar }\end{array}$ & $\begin{array}{c}2 \\
(1)\end{array}$ & 63 \\
\hline $\begin{array}{l}\text { A0A2Y9EH04_PHYMC } \\
\text { Fer-1-like protein } 4\end{array}$ & $\begin{array}{l}\text { Physeter macrocephalus } \\
\text { Sperm whale }\end{array}$ & $\begin{array}{c}3 \\
(1)\end{array}$ & 62 \\
\hline
\end{tabular}


Table 2. Cont.

\begin{tabular}{|c|c|c|c|}
\hline $\begin{array}{c}\text { Protein ID } \\
\text { Protein Name }\end{array}$ & $\begin{array}{l}\text { Species Name } \\
\text { Common Name }\end{array}$ & $\begin{array}{c}\text { Matches } \\
\text { (Sequences) }\end{array}$ & $\begin{array}{l}\text { Total Score } \\
(p<0.05)^{+} \\
\end{array}$ \\
\hline $\begin{array}{c}\text { *A0A286ZRK7_PIG } \\
\text { 60S ribosomal protein }\end{array}$ & $\begin{array}{l}\text { Sus scrofa } \\
\text { Wild boar }\end{array}$ & 1 & 62 \\
\hline $\begin{array}{c}\text { A0A4W2CHE4_BOBOX } \\
\text { IF rod domain-containing protein }\end{array}$ & $\begin{array}{c}\text { Bos indicus } x \text { Bos taurus } \\
\text { Zebu } \times \text { Cow }\end{array}$ & $\begin{array}{c}3 \\
(1)\end{array}$ & 61 \\
\hline $\begin{array}{c}\text { *A0A287BDT6_PIG } \\
\text { Ubiquitin carboxyl-terminal hydrolase }\end{array}$ & $\begin{array}{l}\text { Sus scrofa } \\
\text { Wild boar }\end{array}$ & $\begin{array}{c}2 \\
(1)\end{array}$ & 61 \\
\hline $\begin{array}{l}\text { *A0A287AFA5_PIG } \\
\text { Endoplasmin }\end{array}$ & $\begin{array}{l}\text { Sus scrofa } \\
\text { Wild boar }\end{array}$ & $\begin{array}{c}1 \\
(1)\end{array}$ & 61 \\
\hline $\begin{array}{c}\text { *BIP_BOVIN } \\
\text { Endoplasmic reticulum chaperone BiP }\end{array}$ & $\begin{array}{l}\text { Bos taurus } \\
\text { Cow }\end{array}$ & $\begin{array}{c}1 \\
(1)\end{array}$ & 58 \\
\hline $\begin{array}{c}\text { 0A6B0R269_9CETA } \\
\text { Ig-like domain-containing protein }\end{array}$ & $\begin{array}{l}\text { Bos mutus } \\
\text { Wild yak }\end{array}$ & $\begin{array}{c}1 \\
(1)\end{array}$ & 57 \\
\hline $\begin{array}{c}\text { A0A5N3UHJ8_MUNRE } \\
\text { Ig-like domain-containing protein }\end{array}$ & $\begin{array}{l}\text { Muntiacus reevesi } \\
\text { Chinese muntjac }\end{array}$ & $\begin{array}{c}1 \\
(1)\end{array}$ & 56 \\
\hline $\begin{array}{c}\text { *A0A2Y9M486_DELLE } \\
\text { Protein PRRC2C isoform X8 }\end{array}$ & $\begin{array}{l}\text { Delphinapterus leucas } \\
\text { Beluga whale }\end{array}$ & $\begin{array}{c}9 \\
9 \\
(1)\end{array}$ & 55 \\
\hline $\begin{array}{c}\text { *A0A383Z8A9_BALAS } \\
\text { Putative SEC14-like protein } 6\end{array}$ & $\begin{array}{l}\text { Balaenoptera acutorostrata } \\
\text { scammony } \\
\text { Minke whale }\end{array}$ & $\begin{array}{c}2 \\
(1)\end{array}$ & 53 \\
\hline $\begin{array}{c}\text { *A0A212D225_CEREH } \\
\text { TMED9 }\end{array}$ & $\begin{array}{l}\text { Cervus elaphus hippelaphus } \\
\text { European red deer }\end{array}$ & $\begin{array}{c}1 \\
(1)\end{array}$ & 53 \\
\hline $\begin{array}{c}\text { *A0A0B8RSX6_PIG } \\
\text { Filamin A, alpha }\end{array}$ & $\begin{array}{l}\text { Sus scrofa } \\
\text { Wild boar }\end{array}$ & $\begin{array}{c}2 \\
(1)\end{array}$ & 52 \\
\hline $\begin{array}{c}\text { *A0A452E6D4_CAPHI } \\
\text { Complement C5-like }\end{array}$ & $\begin{array}{l}\text { Capra hircus } \\
\text { Goat }\end{array}$ & $\begin{array}{c}2 \\
(1)\end{array}$ & 52 \\
\hline $\begin{array}{c}\text { A0A6B0RW97_9CETA } \\
\text { Uncharacterized protein (Ig lamda chain variable region) }\end{array}$ & $\begin{array}{l}\text { Bos mutus } \\
\text { Wild yak }\end{array}$ & $\begin{array}{c}1 \\
(1)\end{array}$ & 52 \\
\hline $\begin{array}{l}\text { *A0A212CJY0_CEREH } \\
\text { Transferrin receptor protein } 1\end{array}$ & $\begin{array}{l}\text { Cervus elaphus hippelaphus } \\
\text { European red deer }\end{array}$ & $\begin{array}{c}1 \\
(1)\end{array}$ & 52 \\
\hline $\begin{array}{c}\text { *A0A4W2F326_BOBOX } \\
\text { Anaphylatoxin-like domain-containing protein }\end{array}$ & $\begin{array}{l}\text { Bos indicus } x \text { Bos taurus } \\
\text { Zebu } \times \text { Cow }\end{array}$ & $\begin{array}{c}2 \\
(1)\end{array}$ & 52 \\
\hline $\begin{array}{c}\text { A0A4U1EAQ3_MONMO } \\
\text { Ig-like domain-containing protein }\end{array}$ & $\begin{array}{l}\text { Monodon monoceros } \\
\text { Narwhal }\end{array}$ & $\begin{array}{c}2 \\
(1)\end{array}$ & 50 \\
\hline $\begin{array}{c}\text { A0A286ZJV6_PIG } \\
\text { Annexin }\end{array}$ & $\begin{array}{l}\text { Sus scrofa } \\
\text { Wild boar }\end{array}$ & $\begin{array}{c}1 \\
(1)\end{array}$ & 50 \\
\hline $\begin{array}{c}\text { A0A6B0RTH8_9CETA } \\
\text { Uncharacterized protein } \\
\text { (obscurin, cytoskeletal calmodulin and titin-interacting RhoGEF) }\end{array}$ & $\begin{array}{l}\text { Bos mutus } \\
\text { Wild yak }\end{array}$ & $\begin{array}{c}2 \\
(1)\end{array}$ & 50 \\
\hline 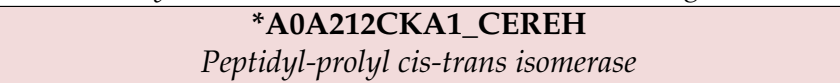 & $\begin{array}{l}\text { Cervus elaphus hippelaphus } \\
\text { European red deer }\end{array}$ & $\begin{array}{c}1 \\
(1)\end{array}$ & 50 \\
\hline $\begin{array}{c}\text { W5P6D4_SHEEP } \\
\text { Uncharacterized protein } \\
\text { (Integrator complex subunit 1) }\end{array}$ & $\begin{array}{l}\text { Ovis aries } \\
\text { Sheep }\end{array}$ & $\begin{array}{c}2 \\
(1)\end{array}$ & 50 \\
\hline $\begin{array}{c}\text { *A0A4W2F827_BOBOX } \\
60 \mathrm{kDa} \text { poly }(U) \text {-binding-splicing factor }\end{array}$ & $\begin{array}{l}\text { Bos indicus } x \text { Bos taurus } \\
\text { Zebu } \times \text { Cow }\end{array}$ & $\begin{array}{c}3 \\
(1)\end{array}$ & 50 \\
\hline $\begin{array}{l}\text { *A0A212CT53_CEREH } \\
\text { Lactadherin }\end{array}$ & $\begin{array}{l}\text { Cervus elaphus hippelaphus } \\
\text { European red deer }\end{array}$ & $\begin{array}{c}2 \\
(1)\end{array}$ & 50 \\
\hline $\begin{array}{c}\text { A0A6B9SDX6_BOVIN } \\
\text { Ig lamda chain variable region }\end{array}$ & $\begin{array}{l}\text { Bos taurus } \\
\text { Cow }\end{array}$ & $\begin{array}{c}1 \\
(1)\end{array}$ & 50 \\
\hline
\end{tabular}

t Ions score is $-10^{*} \log (\mathrm{P})$, where $\mathrm{P}$ is the probability that the observed match is a random event. Individual ions scores $>46$ indicate identity or extensive homology $(p<0.05)$. Protein scores are derived from ions scores as a non-probabilistic basis for ranking protein hits.

Protein hits identified to be deiminated showed 15 shared identified protein hits in plasma and plasma EVs; these were albumin, serum albumin, IF rod domain, keratin, keratin 75 , keratin, type I cytoskeletal 15, bradykinin, TAF domain-containing protein, histone $\mathrm{H} 4$, annexin, junction plakoglobin, $\mathrm{VH}$ region, Ig-like domain, endoplasmic reticulum 
chaperone and obscurin. For whole plasma, 110 hits were identified as specific, while 14 deiminated protein hits were identified to be specific to EVs only (Figure $4 \mathrm{~A}$; for identification of specific hits, see highlighted proteins in Tables 1 and 2). EV-specific hits included keratins (KRT5, KRT17, KRT19), collagen (type I alpha-1 and alpha 2 chain; type III alpha-1 chain and isoform X1), SH3 domain-containing protein, cytoplasmic actin 1, endoplasmic reticulum chaperone $\mathrm{BiP}$, HATPase $\mathrm{c}$ domain-containing protein, ubiquitin-60S ribosomal protein L40, lysozyme, and histone H2B (although a H2B-like protein did also come up as a possible secondary hit for an uncharacterized hit in whole plasma).

Upon protein network analysis for deimination-enriched proteins in whole plasma and plasma EVs, a number of shared and unique GO molecular function, GO biological processes and KEGG pathways were identified as represented by the Venn diagrams in Figure 4B.

A.

\section{Number of Deiminated Protein Targets identified} in Plasma and Plasma-EVs

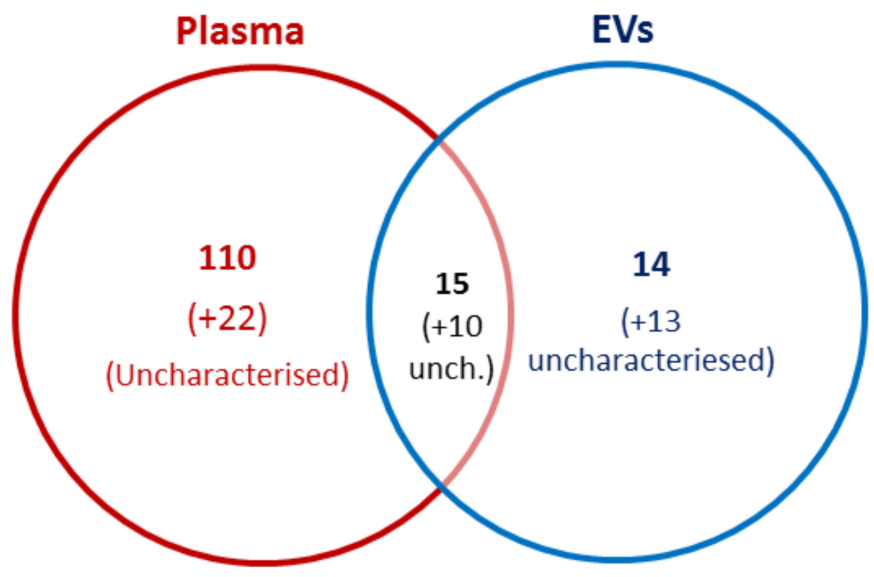

B.

GO Pathway Analysis for Deiminated Protein Targets

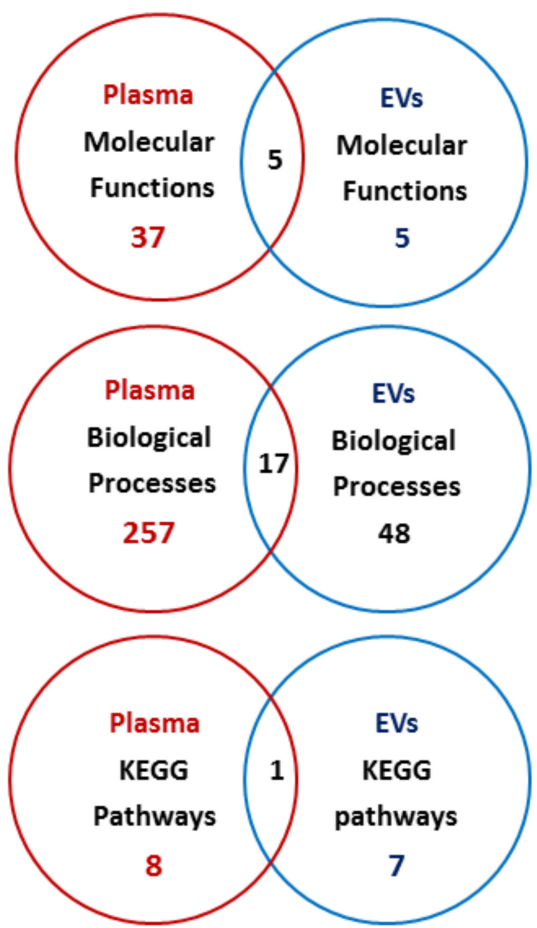

Figure 4. Deiminated protein hits identified in reindeer plasma and plasma EVs. (A) Venn diagram showing deiminated protein hits identified in $R$. tarandus whole plasma and plasma EVs, representing shared and unique proteins hits (uncharacterized hits are indicated in brackets). (B) Venn diagrams showing GO pathway analysis for deiminated proteins identified in plasma and plasma EVs, respectively. The number of Molecular function pathways, Biological Processes and KEGG pathways, which were found enriched in R. tarandus whole plasma and plasma EVs, respectively, as well as shared pathways between whole plasma and plasma EVs, are indicated.

\subsection{Protein-Protein Interaction Network Identification of Deiminated Proteins in Reindeer Plasma} and Plasma EVs

For the prediction of protein-protein interaction networks of the deimination candidate proteins identified in plasma as well as plasma EVs, the protein names were submitted to STRING (Search Tool for the Retrieval of Interacting Genes/Proteins) analysis (https://string-db.org/). A functional protein network analysis was carried out as follows: Protein interaction networks were built based on known and predicted interactions and represent all deiminated proteins identified in $R$. tarandus plasma and plasma EVs, respectively. The interaction networks were based on proteins from the STRING protein database for Bos taurus as a representative species for the Phylum Artiodactyla and for a maximum 
number of hits, as protein identifiers for $R$. tarandus are not available in the STRING. Protein interaction networks enriched in deiminated proteins are represented below for plasma EVs and total plasma, respectively (Figure 5A,B). For both networks, the PPI enrichment $p$-value was found to be $p<1.0 \times 10^{-16}$, which indicates that these proteins are biologically connected as a group and show more interactions among themselves than what would be expected for a random set of proteins of similar size, drawn from the genome.

A. Deiminated proteins network analysis - EVs

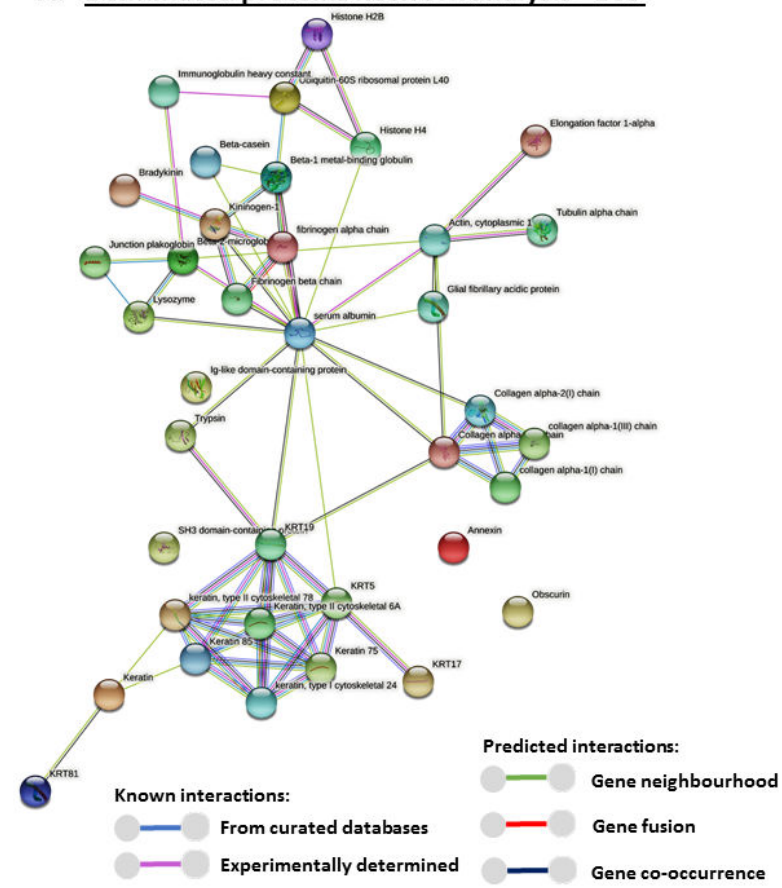

B. Deiminated proteins network analysis - Plasma

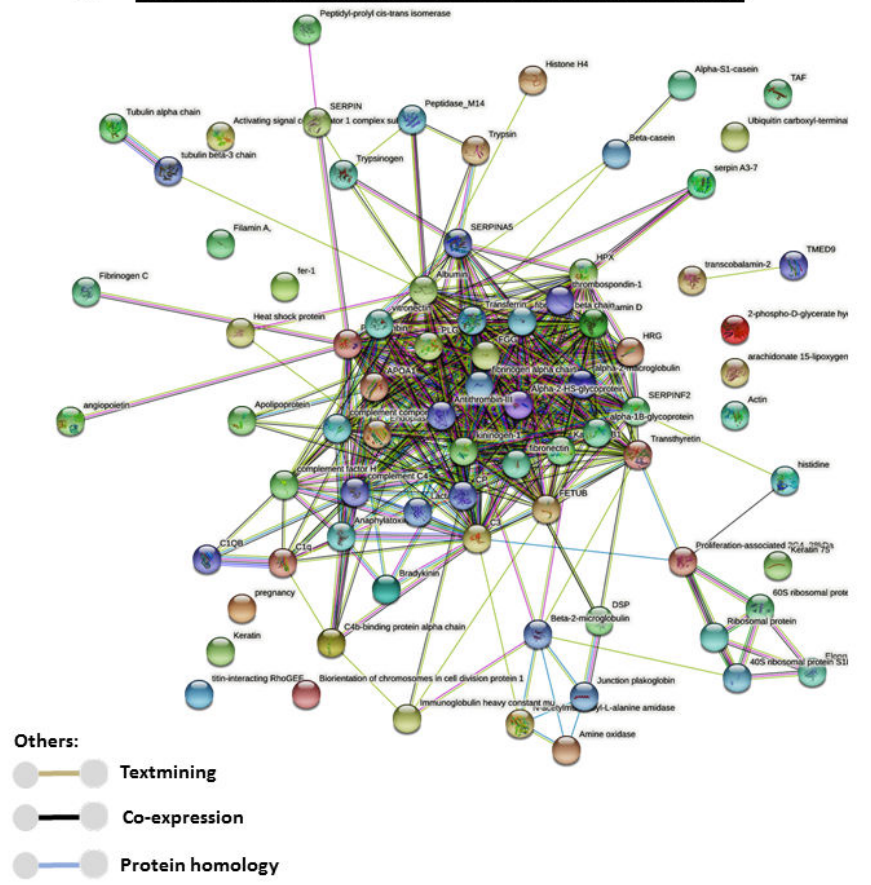

Figure 5. Protein-protein interaction networks of deiminated proteins identified in reindeer plasma EVs and in whole plasma. Protein-protein interaction networks for deiminated proteins in reindeer plasma EVs and whole plasma, based on known and predicted interactions in Bos Taurus as a representative species for Artiodactyla, using Searching Tool for the Retrieval of Interacting Genes/Proteins (STRING) analysis. PPI enrichment $p$-value for both networks is $p<1.0 \times 10^{-16}$. (A) Protein networks enriched in deiminated proteins in reindeer plasma EVs; colored nodes represent query proteins only. (B) Protein networks enriched in deiminated proteins in reindeer whole plasma; colored notes represent query proteins only. Colored lines connecting the nodes show the type of interactions between the nodes in the networks; this is based on known interactions, predicted interactions and other (including textmining, co-expression and protein homology); the color code is provided in the figure.

STRING analysis was further used to identify KEGG pathways (Kyoto Encyclopaedia of Genes and Genomes pathways) for the deiminated protein candidates in plasma EVs and whole plasma, and these are highlighted in Figure 6. In plasma EVs, eight KEGG pathways were identified (Figure 6A), while nine KEGG pathways enriched in deiminated proteins were identified in whole plasma (Figure 6B); the only common pathway between plasma EVs and whole plasma was the complement and coagulation pathway (Figure 6). KEGG pathways identified in EVs were: protein digestion and absorption, platelet activation, amoebiasis, the AGE-RAGE signaling pathway in diabetic complications, ECM receptor interaction, the relaxin signaling pathway and the estrogen signaling pathway (Figure 6A). In whole plasma, deimination-enriched KEGG pathways (in addition to the complement and coagulation cascade) were: Staphylococcus aureus infection, prion diseases, vitamin digestion and absorption, pertussis, ferroptosis, SLE, thyroid hormone synthesis and phagosome (Figure 6B). 


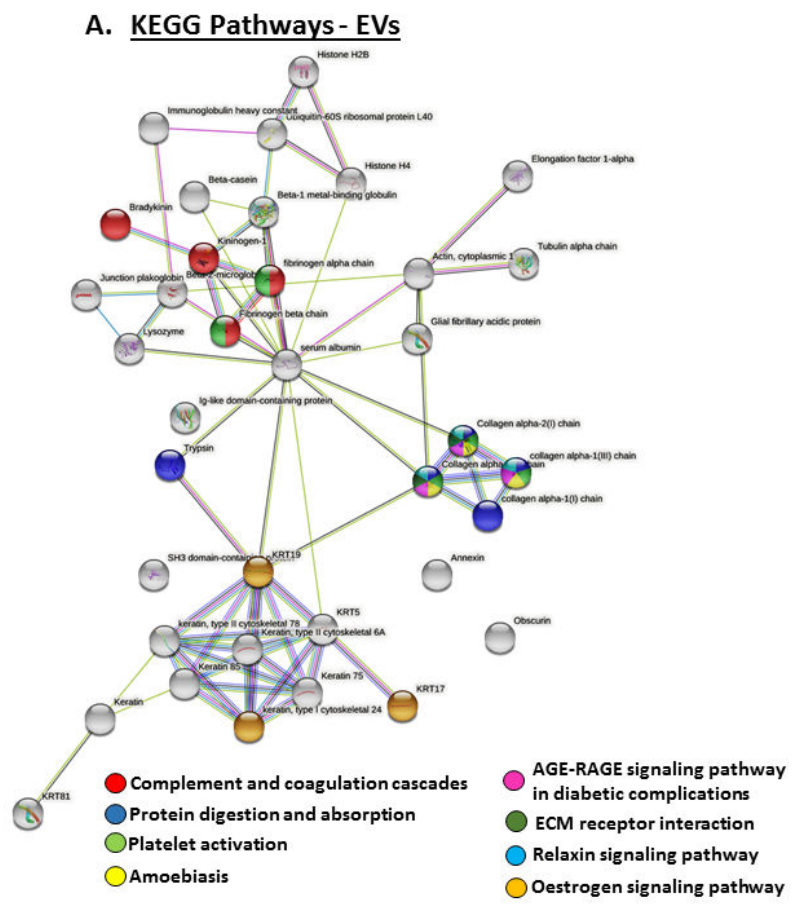

\section{B. KEGG Pathways - Plasma}

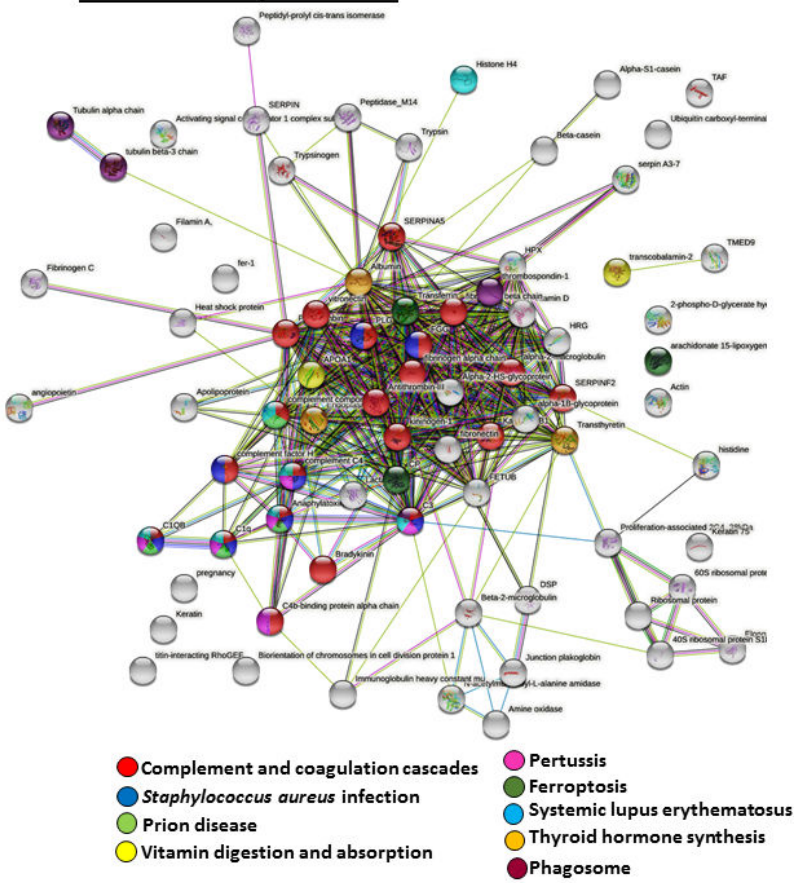

Figure 6. KEGG pathways for deiminated proteins identified in reindeer plasma EVs and whole plasma. Protein-protein interaction networks identified in reindeer plasma are based on known and predicted interactions in Bos taurus as a representative Artiodactyla for creation of the protein networks, using Searching Tool for the Retrieval of Interacting Genes/Proteins (STRING) analysis. (A) KEGG pathways in plasma EVs are highlighted, with eight pathways identified for the deimination protein networks. (B) KEGG pathways in whole plasma are highlighted; nine pathways were identified for the deimination protein networks. The color code for the specific KEGG pathways for both networks is indicated in $(\mathbf{A}, \mathbf{B})$, respectively.

Protein networks of deiminated proteins in plasma EVs were also analyzed for GO biological processes and GO molecular function and STRING protein networks for these processes are provided in Supplementary Figure S1A,B, respectively. Similarly, whole plasma deimination STRING protein networks for GO biological processes and GO molecular function are provided in Supplementary Figure S2A,B respectively.

\section{Discussion}

This is the first study to assess extracellular vesicles (EV) and protein deimination signatures in reindeer plasma and plasma EVs. The current study aimed to provide novel insights into roles for post-translational regulation of reindeer immunity and metabolism while also highlighting putative roles for post-translational deimination in the functional diversification of conserved protein pathways throughout phylogeny.

Reindeer plasma EVs showed a poly-dispersed population in the size range of $40-500 \mathrm{~nm}$ with the majority of EVs falling in the range of $100-250 \mathrm{~nm}$, which is a similar size distribution as previously described for Bos taurus plasma EVs [20], and similar as observed for human EVs. Reindeer plasma EVs showed positive for the phylogenetically conserved EV-specific markers CD63 and Flotllin-1, and were furthermore verified by transmission electron miscopy.

PAD isozymes were assessed in both reindeer plasma and plasma EVs by Western blotting, using anti-human PAD2-, PAD3- and PAD4-specific antibodies, revealing the presence of these three PAD isozymes in reindeer whole plasma at the predicted size of 70-75 kDa as seen for other mammals, while only PAD4 was shown to be exported in reindeer plasma EVs. This may be of considerable interest as the different PAD isozymes vary in their specificity for target proteins, with PAD4 having a narrower target selection than PAD2 [35], and this may therefore also reflect some of the differences observed in deiminated proteins 
found inside EVs, compared with deiminated proteins in whole plasma. Additionally, in comparison with previous assessment of alligator plasma EVs, where PAD2 was found in abundance in EVs, alongside low levels of PAD3 but no PAD4 export the EVs, such differences in EV-mediated PAD isozyme transport indicates differences in PAD mediated communication via EVs across animal phyla and may contribute to immune diversity observed across phylogeny. It must be noted that neither PAD1, which is associated mainly with skin and skin diseases, or PAD6, which is linked to fertility and pre-implantation embryo, were assessed in reindeer plasma in the current study.

To identify deiminated protein targets in plasma and plasma EVs of reindeer, F95 enrichment with tandem mass spectrometry was carried out. This analysis revealed some differences between hits in whole plasma and plasma EV cargo: overall, 110 deiminated proteins were identified to be specific to whole plasma and 14 deiminated proteins were identified in plasma EVs only; in addition, 15 deiminated protein hits were found to be shared between whole plasma and plasma EVs. Further uncharacterized proteins were also identified in both plasma and plasma EVs. Overall, this indicates differences of deimination mediated functions in cellular communication via EVs, compared with whole plasma, and functional protein network analysis for these deiminated protein hits in reindeer plasma and plasma EVs was therefore performed using STRING analysis. This revealed differences in deimination enrichment in functional protein networks of Kyoto Encyclopaedia of Genes and Genomes (KEGG) pathways, as well as Gene Ontology (GO) pathways for biological processes and molecular functions as discussed below:

KEGG pathways shared for deiminated proteins in whole plasma and plasma EVs were complement and coagulation pathways. Additional KEGG pathways which were specific for deiminated proteins in plasma EVs included ECM receptor interaction, platelet activation, amoebiasis, the estrogen signaling pathway, the AGE-RAGE signaling pathway in diabetic complications, the relaxin signaling pathway, as well as in protein digestion and absorption. KEGG pathways specific for deiminated proteins in whole plasma were pertussis, ferroptosis, phagosome, Staphylococcus aureus infection, systemic lupus erythematosus (SLE), prion disease, thyroid hormone synthesis, vitamin digestion and absorption.

Of interest is that while the complement and coagulation system was identified as deiminated in both whole plasma and plasma EVs, differences were observed in the target proteins of deimination which participate in these cascades. In plasma EVs, proteins connected to complement and the coagulation system and identified as deimination candidates were fibrinogen, kinogenin and bradykinin. The complement system has important roles in clearing invading pathogens, as well as necrotic and apoptotic cells, and bridges innate and adaptive immunity [62]. In whole plasma, key complement components including $\mathrm{C} 1 \mathrm{q}, \mathrm{C} 3, \mathrm{C} 4, \mathrm{C} 5, \mathrm{C} 9$, as well as factor $\mathrm{H}$ and the $\mathrm{C} 3 / \mathrm{C} 5$ convertase were identified as deiminated. Deimination of complement components has previously been reported for a various complement components, including some identified here, in serum and plasma from a range of species [12-25,29]. Interestingly, in bovine serum-EVs, a number of deiminated complement components has been identified, including C1q, C3, C4A, C5a, C7, C8, C9 factor B, Factor H, C4-binding protein [20], while in teleost fish serum both C3 and C4 were identified in deiminated form but in teleost serum-EVs $\mathrm{C} 3$ was more dominant in deiminated form, compared with $C 4[12,13,16]$. This indicates that deimination mediated regulation of complement-related mechanisms, including via EVs, may differ between animal species and may possibly also link to different export of PAD isoforms in EVs between species-also bearing in mind that lower in phylogeny, only one PAD form will be responsible for all deimination, while in mammals there are more PAD isoyzmes with target-specific preferences.

In EVs, deimination enrichment for amoebiasis and platelet activation KEGG pathways were identified, both of which have also been found deiminated in cattle [20] and relate to anti-pathogenic and injury responses. The ECM receptor interaction KEGG pathway was also identified as enriched in deiminated proteins and plays multifaceted roles (both direct and indirect) in apoptosis, cell adhesion, cell differentiation, migration and 
proliferation. The ECM receptor interaction pathway is also related to anti-bacterial and anti-viral responses [63,64], as well as cancer [65]; furthermore, deimination enrichment in this pathway has been identified in brain cancer [50]. The ECM receptor interaction pathway has been found enriched in deiminated proteins in cattle [20], in long lived and cancer resistant animals such as whale [14] and long-lived birds such as albatross [25], as well as in alligator, an animal with unusual anti-bacterial and anti-viral responses [18]. In EVs, the estrogen signaling pathway was identified to be enriched in deiminated proteins, and this was also previously observed in bovine plasma EVs [20]. Deimination in estrogen signaling may be of considerable interest as estrogen receptors are expressed broadly in innate and adaptive immune-related cells and also affect cytokine production, and are furthermore involved in immune regulation in the tumour environment [66]. The AGE-RAGE signaling pathway, also enriched in deiminated proteins in EVs, relates to diabetic complications [67], age- and stress-related arterial diseases [68] as well as playing multifaceted roles in cancer progression, including cell death control (apoptosis, autophagy and necroptosis), cytokine release and EMT, including in chronic mucosal inflammation [69-71]. Deimination enrichment in the relaxin signaling pathway was also identified to be specific to plasma EVs. This may be of considerable interest as relaxin mediates a range of biological functions including anti-apoptotic, anti-fibrotic, angiogenic, vasodilatory and anti-inflammatory responses [72]. Metabolic-related KEGG pathway identified as enriched in deiminated proteins for plasma EVs was for protein digestion and absorption. As the regulation of protein metabolism in ruminants has been studied due to importance in farming [73], putative signaling regulation in this pathway via deimination may be of some interest.

In plasma, the specific deimination-enriched KEGG pathways, besides complement and coagulation cascade, related to both immunity and metabolism. Immune-related KEGG pathways were ferroptosis, phagosome, pertussis, Staphylococcus aureus infection, systemic lupus erythematosus (SLE) and prion disease. This indicates a number of deiminationregulated pathways involved both in antimicrobial responses as well as autoimmunity and neurodegeneration. Cell death via ferroptosis is an iron-dependent process which occurs via iron accumulation and lipid peroxitation, resulting in oxidative cell death and related to a range of pathological processes, including nervous system disease, ischemia-reperfusion and cancer $[74,75]$. Therefore, insights into roles for deimination may be of considerable interest in this type of cell death. SLE is a known deimination-related autoimmune disease, alongside a number of other connective tissue autoimmune diseases [76], and therefore enrichment in autoimmune pathways was not unexpected. Similarly, prion diseases have been linked to deimination and are further discussed in detail below. Metabolic pathways enriched in deiminated proteins in plasma were thyroid hormone synthesis and vitamin digestion and absorption. The thyroid hormone synthesis pathway plays roles in the regulation of metabolism and energy homeostasis, regulation of insulin and thermogenesis, and is also linked to stress $[77,78]$, alongside a range of pathologies including cancer, obesity, dyslipidemia, degenerative brain disease and dementia [79]. Regulation of the thyroid hormone synthesis pathway via epigenetic modifications of histones has also been reported [80] and this pathway has previously been linked to deimination enrichment in whales [14]. Furthermore, PADs and deimination have been linked to autoimmune thyroid disease and thyroid cancer [81,82]. Deimination enrichment in the vitamin digestion and absorption pathway may furthermore contribute to diverse roles of vitamin processing, which in reindeer is critical as they have undergone adaptions for vitamin D metabolism [1], and indeed vitamin D-binding protein was identified as a deimination candidate in whole plasma. Interestingly, vitamin D-binding protein has also been identified as a deimination candidate in camelids [19], which are also metabolically adapted to extreme environments.

Numerous GO biological pathways were furthermore identified in plasma and plasma EVs (Supplementary Figures S1A and S2A), with 257 pathways in plasma and 48 in EVs, while 17 were shared between plasma and plasma EVs. Shared pathways were: tricovalent inorganic cation transport, blood coagulation, cytolysis, regulation of body fluid levels, response to alcohol, iron ion homeostasis, digestion, negative regulation of developmental 
process, metal ion transport, iron ion transport, platelet activation, negative regulation of multicellular organismal process, metal ion homeostasis, positive regulation of multicellular organismal process, response to endogenous stimulus, response to abiotic stimulus.

Molecular function GO pathways identified for F95-enriched proteins and shared for whole plasma and plasma EVs (Supplementary Figures S1B and S2B) were: metal ion binding, identical protein binding, cysteine-type endopeptidase inhibitor activity, serine-type endopeptidase activity and structural molecule activity. In whole plasma, $42 \mathrm{GO}$ molecular pathways were identified for deiminated proteins, 5 of which were shared with EVs. Molecular GO pathways specific for deiminated proteins in EVs were: the platelet-derived growth factor-binding pathway, extracellular matrix structural constituent, pyridoxal phosphate binding, protease binding and protein binding (Supplementary Figures S1 and S2).

Deimination enrichment in the various metabolic and immune-related pathways identified here may be of considerable relevance for physiological and pathobiological processes in reindeer. Importantly, reindeer have undergone a number of immune as well as metabolic adaptions, including for fat metabolism processes, limited heat loss and low resting metabolic rate, as well as changes to their internal biological clock [1,2]. Comparative genome analysis of reindeer has identified specifically adopted factors involved in immunity, vitamin D metabolism, retinal development, circadian rhythm, tolerance to cold-triggered pain and antler development [1]. Indeed, we identified deimination enrichment in numerous metabolic pathways, including vitamin and lipid metabolic pathways such as vitamin digestion and absorption, regulation of lipoprotein, lipid metabolism, cholesterol transport and efflux, fatty acid biosynthesis, regulation of ketone metabolic processes, lipid and vitamin binding. Other deimination-enriched pathways included protein digestion and absorption, the estrogen signaling pathway and thyroid hormone synthesis, as discussed above. Interestingly also, some differences were again observed between whole plasma and plasma EVs, indicating some differences in cellular communication in metabolic processes relating to EVs, as listed above (see also Supplementary Figures S1 and S2 for GO biological and GO molecular pathways).

A large number of pathways relating to defense and stress responses, innate and adaptive immunity, including the activation and regulation of immunity, humoral antimicrobial immunity, response to bacterium and parasites, complement-related functions, apoptosis and phagocytosis, iron metabolism, cytokine regulation as well as symbiosis, were here among many other immune-related pathways found to be enriched in deiminated proteins (Figure 6; Supplementary Figures S1 and S2). Furthermore, histones, which are known to act as anti-pathogenic agents. were here found to be deiminated in plasma and plasma EVs. While mainly histone $\mathrm{H} 3$ deimination has been studied in anti-pathogenic responses relating to extracellular trap formation (NETosis/ETosis), roles for antimicrobial effects of $\mathrm{H} 2$ and $\mathrm{H} 4$ histones has also been established, including anti-viral ones [83]. Their deimination in anti-pathogenic responses remains to be further investigated, but has been linked to gene regulatory events, including in cancer [84]. In plasma, a number of serpins were identified to be deiminated. These serine proteinases have multifaceted roles in protease inhibition, chromatin organization, hormone transport, control of apoptosis, as well as in anti-microbial and anti-viral responses [85-88]. Overall, our findings point to roles for deimination in immune response modulation, possibly allowing for protein moonlighting in health and disease and in response to various pathogenic infections via this post-translational modification. Indeed, reindeer have been widely studied in relation to a number of naturally occurring infections including parasitic bacterial and viral ones and are also related to a range of zoonotic diseases [8]; these are summarized below:

With respect to parasitic infections, more than 100 parasite species have been reported to infect or infest reindeer [89-94], many of which are also shared with other ruminants. Protozoan parasites include Eimeria species [95], Cryptosporidium and Giardia [96], Entamoeba [97], Besnoitia [98,99] and Toxoplasma gondii [100-103]. Reindeer in Fennoscandia are intermediate hosts for Sarcocystis spp. [104,105]. Haematozoan parasites include Babesia spp. and Trypanosoma spp. [94]. The rumen fluke Paramphistomum leydeni and the liver fluke 
Dicrocoelium dendriticum (Trematoda) also infect reindeer [106,107]. Furthermore, a number of Cestoda paraitize reindeer, acting either as intermediate or final hosts [91,108-110]. Nematoda form the most common and versatile group of parasites in reindeer and are most often associated with intestine [91,93,107,111-115], but can also be found in the capillaries of the ears and eyelids [116,117], or be bloodborne [118]. Some nematodes are also confined to the central nervous system (CNS) and can cause paralysis; a major concern in reindeer breeding [119], while others affect the lung [91,120,121]. Additionally, the arthropod sinus worm Linguatula arctica is widespread and common parasite of reindeer [91,122] and ectoparasites also infest reindeer [67], causing skin and mucosal swelling, bleeding and affect breathing [91,123-125]. Importantly, parasitic infections from reindeer can also be zoonotic, for example Enterocytozoon bieneusi-a microsporidia and obligate parasite infecting intestinal cells, is suggested to be transmitted to humans [126].

A number of naturally occurring viral infections have also been identified in reindeer, including alphaherpesvirus, bluetongue virus, malignant catarrhal fever (MCFV-)-related gammaherpesvirus, pestivirus, Schmallenberg virus [7,8,127-129], West Nile virus which leads to lymphohistiocytic encephalomyelitis [7] and tick-borne encephalitis virus (TBEV), which belongs to the most important neurological pathogens transmitted by tick bites in Europe [130]. Further viruses include papillomaviruses, parvovirus, and polyomavirus, as well as importantly also Coronaviridae [131]. Experimental viral infections in reindeer include herpesvirus 2 and parapoxvirus, both of which have though also been detected in Norwegian reindeer [129], including semi-domesticated reindeer [132] as well as in Alaskan caribou and other wildlife, and are known to be transmitted between wildlife, sheep, goats and human [5].

Importantly, the white-tailed deer (Odocoileus virginianus) has recently been proven to be experimentally infected via intranasal inoculation with SARS-CoV-2, showing evidence of subclinical viral infection as well as shedding of infectious virus in nasal secretions and feces, as well as detection of viral RNA in multiple tissues [9]. These findings point to deer as a putative new zoonotic host for the virus, although it still needs to be further established whether the infection will also happen naturally, and therefore contribute as a novel viral reservoir [9]. Whether there is a possibility of zoonotic transmission from deer back to humans, as recently observed in mink [133-135], also needs to be established, as well as if other Cervidae, including reindeer, can act as zoonotic hosts and reservoirs for SARS-CoV-2. Furthermore, it must be considered that reindeer do come in close contact with sheep through shared grounds for grazing, and may also encounter other domestic or wild animals on shared habitats elsewhere, and this could possibly be another concern regarding zoonosis spread.

Bacterial infections described in reindeer include Anaplasma phagocytophilum, which in sheep and cattle causes tick-borne fever and can in human cause the zoonotic disease granulocytic anaplasmosis [8]. Evidence for transmission of Lyme disease, which is caused by Borrelia bugdorferi, a tick-borne encephalitis associated bacterium, has furthermore been described from reindeer to human following skinning of a reindeer, causing meningoencephalitis [6]. Reindeer are also subject to tuberculosis, caused by Mycobacterium bovis [136], as well as polymicrobial bronchopneumonia caused by Mycoplasma ovipneumoniae [137]. Brucella spp., is a zoonotic bacteria that is one of the most widespread and economically impactful zoonosis affecting reindeer and can be transmitted to human via raw animal products, including from reindeer and caribou $[138,139]$. Anthrax, a global zoonotic and epizoonotic disease, is another bacterial pathogen identified in reindeer, particularly in relation to infected carcasses, as recently found in Siberian permafrost and therefore also indicative of a possible rise in the Arctic due to climate change [140]. Reindeer have in addition been found to carry Clostridium perfringens [141] and can suffer from severe bacterial intestinal infections and endotoxemia by Clostridium sp [142,143], while other bacteria inside the order Clostridiales aid in processing of lichen secondary metabolites [144]. Reindeer also carry Erysipelothrix rhusiopathiae- which relates to urticaria-like lesions, arthralgia, arthritis, endocarditis and sepsis and can furthermore be transmitted to humans [145]. This 
may be of interest as both bacterial and autoimmune disease pathways were here identified to be linked to deiminated proteins in reindeer plasma via STRING analysis.

The strong relationship of deimination-enriched proteins with a number of immunerelated pathways may therefore be important in relation to the infections listed above, both naturally occurring ones as well as zoonotic ones. It also has to be considered that PADs are phylogenetically conserved proteins which are also found in bacteria and parasites, both of which can use their PAD homologues to manipulate host immunity $[39,40]$. Therefore the interplay of host-pathogen post-translational regulation is a field which requires further investigation.

Importantly, in the current study, deimination-enriched pathways were also identified for prion disease and amyloid in whole plasma. This is indicative of that deimination plays roles in prion diseases in reindeer. Deer are well known to be affected by prionrelated transmissible spongiform encephalopathy, a neurodegenerative disease which in reindeer manifests as chronic wasting disease (CWD), and is also found in deer, elk and moose $[4,146,147]$. Its transmission is believed to be primarily transmitted via direct contact of oral and mucosal membranes between positive and susceptible animals, also via feces and urine, as well as prion reservoirs in soil and water $[148,149]$. In white tailed deer, differential gene expression analysis for CWD has identified links to various cellular components, as well as retroviral infection [150]. Previous studies have indeed related protein deimination to prion disease including Creutzfeldt-Jacob Disease and scrapie [151-155], via effects on prion conformation, enolase, protein accumulation and pathogenesis, although further in depth examination into exact mechanistic pathways is still needed. Furthermore, a recent animal study on early pre-motor Parkinson's disease (PD) identified enrichment of deiminated proteins in pathways relating to prion disease in the PD, versus control animals [156], further highlighting deimination as a common factor in various neurodegenerative disorders, including prion diseases. It may therefore be of considerable importance that deimination was identified here also in prion disease-related pathways in reindeer as this shows conserved pathways across phyla. Furthermore, the disease is spreading geographically including in the US, Canada, Scandinavia and South Korea [147] and therefore understanding underlying pathways to develop measures for reducing transmission between animals, including domestic ones such as cattle, sheep and swine, as well as possible transmission to human, including via consumption of infected deer and elk, is of considerable importance [149,157-160].

It must be noted that the analysis of protein networks enriched in deiminated proteins presented here relied on deimination enrichment using the pan-citrulline-specific F95 antibody, and therefore further evaluation, including that of individual candidate proteins for deimination and using other citrulline signature proteomic approaches, should also be considered. The protein networks presented are based on functional protein network analysis, which besides experimentally established interactions also takes into account indirect and functional interactions. The protein network analysis is furthermore based on protein hits identified in the Artiodactyla UniProt database, and using Bos taurus as a representative species for Artiodactyla, as a species-specific reindeer proteomic database is not available in STRING. It must also be considered that the current study only assessed female reindeer that were assessed as healthy, and therefore further investigations into deimination and EV signatures relating to sex differences and health status remain subject to further in depth investigations. Nonetheless, this study provides a base line for furthering understanding of the roles of deimination and EVs in reindeer immunity and metabolism and may provide a platform for the development of novel biomarkers to assess wild life health status and zoonotic disease transmission.

\section{Conclusions}

The current study characterized PAD expression and deiminated protein product signatures in plasma and plasma extracellular vesicles (EVs) of reindeer ( $R$. tarandus). Some differences were observed for PAD isozyme PAD2, PAD3 and PAD4 detection in 
whole plasma versus plasma EVs, with only PAD4 being exported in the EVs. Protein deimination signatures of whole plasma versus plasma EVs confirmed a range of KEGG and GO pathways relating to key immune and metabolic functions, including pathways for innate and adaptive immunity, prion disease, as well as hormonal regulation, vitamin and lipid metabolism. This provides novel insights into the roles for post-translational protein deimination in the regulation of key pathways involved in physiological and pathophysiological processes and further links to various known pathways in deer relating to infection and immunity in pathogenic and prion diseases. Furthermore, deimination may contribute to various unique adaptions of reindeer immune and metabolic pathways, which warrants further investigation. Importantly, as reindeer can play roles as reservoir hosts for a range of pathogens circulating in captive, wild as well as domestic ruminant species, and be a reservoir for zoonotic disease, including coronaviruses, bacterial and parasitic ones, the current study provides novel insights into their immune systems, which may be critically relevant in understanding of zoonosis spread and management.

Supplementary Materials: The following are available online at https:/ /www.mdpi.com/2079-773 7/10/3/222/s1, Table S1: Full LC-MS/MS analysis of F95-enriched proteins identified in reindeer (R. tarandus) plasma EVs. Table S2: Full LC-MS/MS analysis of F95-enriched proteins identified in reindeer ( $R$. tarandus) whole plasma. Figure S1: A. Biological processes GO pathways for STRING protein networks of deiminated proteins in reindeer ( $R$. tarandus) plasma EVs. B. Molecular function GO pathways for STRING protein networks of deiminated proteins in plasma EVs. Figure S2: A. Biological processes GO pathways for STRING protein networks of deiminated proteins in reindeer (R. tarandus) whole plasma. B. Molecular function GO pathways for STRING protein networks of deiminated proteins in reindeer ( $R$. tarandus) whole plasma.

Author Contributions: Conceptualization, S.L.; methodology, S.D., S.T., I.K. and S.L.; validation, S.D., K.S. and S.L.; formal analysis, S.D. and S.L.; investigation, S.D., S.T., K.S. and S.L.; resources, S.T., I.K., K.S. and S.L.; data curation, S.L.; writing—original draft preparation, S.L.; writing—review and editing, S.D., S.T., K.S. and S.L.; visualization, S.D., I.K. and S.L.; supervision, S.L.; project administration, S.L.; funding acquisition S.L. All authors have read and agreed to the published version of the manuscript.

Funding: This research was supported in parts by University of Westminster internal funding to S.L.; S.D.A. is supported by a University of Westminster SLS PhD studentship.

Institutional Review Board Statement: Reindeer sample collection was in accordance with Icelandic laws and regulations on sampling from wild animals (64/1994). This study was conducted under license from the Institute for Experimental Pathology, University of Iceland, number \#0001 kt650269-4549, approved by the central animal ethics committee in Iceland (Icelandic Food Regulation Authority, MAST Matvælastofnun).

Data Availability Statement: Data are contained within the article and supplementary material.

Acknowledgments: The authors would like to thank Yagnesh Umrania and Michael Deery at the Cambridge Centre for Proteomics for the LC-MS/MS. Thanks are due to The Guy Foundation for funding the purchase of equipment utilized in this work.

Conflicts of Interest: The authors declare no conflict of interest.

\section{References}

1. Weldenegodguad, M.; Pokharel, K.; Ming, Y.; Honkatukia, M.; Peippo, J.; Reilas, T.; Røed, K.H.; Kantanen, J. Genome sequence and comparative analysis of reindeer (Rangifer tarandus) in northern Eurasia. Sci. Rep. 2020, 10, 8980. [CrossRef]

2. Lin, Z.; Chen, L.; Chen, X.; Zhong, Y.; Yang, Y.; Xia, W.; Liu, C.; Zhu, W.; Wang, H.; Yan, B.; et al. Biological adaptations in the Arctic cervid, the reindeer (Rangifer tarandus). Science 2019, 364, eaav6312. [CrossRef] [PubMed]

3. Williams, E.S.; Young, S. Chronic wasting disease of captive mule deer: A spongiform encephalopathy. J. Wildl. Dis. 1980, 16, 89-98. [CrossRef] [PubMed]

4. Moore, S.J.; Kunkle, R.; Greenlee, M.H.; Nicholson, E.; Richt, J.; Hamir, A.; Waters, W.R.; Greenlee, J. Horizontal Transmission of Chronic Wasting Disease in Reindeer. Emerg. Infect. Dis. 2016, 22, 2142-2145. [CrossRef] [PubMed]

5. Tryland, M.; Beckmen, K.B.; Burek-Huntington, K.A.; Breines, E.M.; Klein, J. Orf virus infection in Alaskan mountain goats, Dall's sheep, muskoxen, caribou and Sitka black-tailed deer. Acta Vet. Scand. 2018, 60, 12. [CrossRef] 
6. Pollard, C.A.; Burns, D.S.; Ho, B.; Johnston, A.M. Meningoencephalitis in a Royal Marine after skinning reindeer in Norway. J. R. Army Med. Corps 2018, 164, 117-119. [CrossRef] [PubMed]

7. Palmer, M.V.; Stoffregen, W.C.; Rogers, D.G.; Hamir, A.N.; Richt, J.A.; Pedersen, D.D.; Waters, W.R. West Nile virus infection in reindeer (Rangifer tarandus). J. Vet. Diagn Investig. 2004, 16, 219-222. [CrossRef]

8. Sánchez Romano, J.; Grund, L.; Obiegala, A.; Nymo, I.H.; Ancin-Murguzur, F.J.; Li, H.; Król, N.; Pfeffer, M.; Tryland, M. A Multi-Pathogen Screening of Captive Reindeer (Rangifer tarandus) in Germany Based on Serological and Molecular Assays. Front. Vet. Sci. 2019, 6, 461. [CrossRef]

9. Palmer, M.V.; Martins, M.; Falkenberg, S.; Buckley, A.; Caserta, L.C.; Mitchell, P.K.; Cassmann, E.D.; Rollins, A.; Diel, D.G. Susceptibility of white-tailed deer (Odocoileus virginianus) to SARS-CoV-2. J. Virol. 2021. [CrossRef]

10. Taylor, R.S.; Horn, R.L.; Zhang, X.; Golding, G.B.; Manseau, M.; Wilson, P.J. The Caribou (Rangifer tarandus) Genome. Genes 2019, 10, 540. [CrossRef]

11. Cronin, M.A.; Macneil, M.D.; Patton, J.C. Mitochondrial DNA and microsatellite DNA variation in domestic reindeer (Rangifer tarandus tarandus) and relationships with wild caribou (Rangifer tarandus granti, Rangifer tarandus groenlandicus, and Rangifer tarandus caribou). J. Hered. 2006, 97, 525-530. [CrossRef]

12. Magnadottir, B.; Kraev, I.; Guđmundsdóttir, S.; Dodds, A.W.; Lange, S. Extracellular vesicles from cod (Gadus morhua L.) mucus contain innate immune factors and deiminated protein cargo. Dev. Comp. Immunol. 2019, 99, 103397. [CrossRef]

13. Magnadottir, B.; Uysal-Onganer, P.; Kraev, I.; Dodds, A.W.; Gudmundsdottir, S.; Lange, S. Extracellular vesicles, deiminated protein cargo and microRNAs are novel serum biomarkers for environmental rearing temperature in Atlantic cod (Gadus morhua L.). Aquac. Rep. 2020, 16, 100245. [CrossRef]

14. Magnadottir, B.; Uysal-Onganer, P.; Kraev, I.; Svansson, V.; Hayes, P.; Lange, S. Deiminated proteins and extracellular vesiclesNovel serum biomarkers in whales and orca. Comp. Biochem. Physiol. Part D Genom. Proteom. 2020, 34, 100676. [CrossRef]

15. Magnadottir, B.; Uysal-Onganer, P.; Kraev, I.; Svansson, V.; Skírnisson, K.; Lange, S. Deiminated proteins and extracellular vesicles as novel biomarkers in pinnipeds: Grey seal (Halichoerus gryptus) and harbour seal (Phoca vitulina). Biochimie 2020, 171-172, 79-90. [CrossRef] [PubMed]

16. Magnadóttir, B.; Kraev, I.; Dodds, A.W.; Lange, S. The Proteome and Citrullinome of Hippoglossus hippoglossus Extracellular Vesicles-Novel Insights into Roles of the Serum Secretome in Immune, Gene Regulatory and Metabolic Pathways. Int. J. Mol. Sci. 2021, 22, 875. [CrossRef]

17. Criscitiello, M.F.; Kraev, I.; Lange, S. Deiminated proteins in extracellular vesicles and plasma of nurse shark (Ginglymostoma cirratum)—Novel insights into shark immunity. Fish. Shellfish Immunol. 2019, 92, 249-255. [CrossRef] [PubMed]

18. Criscitiello, M.F.; Kraev, I.; Petersen, L.H.; Lange, S. Deimination Protein Profiles in Alligator mississippiensis Reveal Plasma and Extracellular Vesicle-Specific Signatures Relating to Immunity, Metabolic Function, and Gene Regulation. Front. Immunol. 2020, 11, 651. [CrossRef] [PubMed]

19. Criscitiello, M.F.; Kraev, I.; Lange, S. Deiminated proteins in extracellular vesicles and serum of llama (Lama glama)-Novel insights into camelid immunity. Mol. Immunol. 2020, 117, 37-53. [CrossRef]

20. Criscitiello, M.F.; Kraev, I.; Lange, S. Post-translational protein deimination signatures in serum and serum-extracellular vesicles of Bos taurus reveal immune, anti-pathogenic, anti-viral, metabolic and cancer-related pathways for deimination. Int. J. Mol. Sci. 2020, 21, 2861. [CrossRef] [PubMed]

21. Bowden, T.J.; Kraev, I.; Lange, S. Extracellular vesicles and post-translational protein deimination signatures in haemolymph of the American lobster (Homarus americanus). Fish. Shellfish Immunol. 2020, 106, 79-102. [CrossRef]

22. Bowden, T.J.; Kraev, I.; Lange, S. Post-translational protein deimination signatures and extracellular vesicles (EVs) in the Atlantic horseshoe crab (Limulus polyphemus). Dev. Comp. Immunol. 2020, 110, 103714. [CrossRef] [PubMed]

23. Bowden, T.J.; Kraev, I.; Lange, S. Extracellular Vesicles and Post-Translational Protein Deimination Signatures in Mollusca-The Blue Mussel (Mytilus edulis), Soft Shell Clam (Mya arenaria), Eastern Oyster (Crassostrea virginica) and Atlantic Jacknife Clam (Ensis leei). Biology 2020, 9, 416. [CrossRef] [PubMed]

24. Pamenter, M.E.; Uysal-Onganer, P.; Huynh, K.W.; Kraev, I.; Lange, S. Post-translational deimination of immunological and metabolic protein markers in plasma and extracellular vesicles of naked mole-rat (Heterocephalus glaber). Int. J. Mol. Sci. 2019, 20, 5378. [CrossRef] [PubMed]

25. Phillips, R.A.; Kraev, I.; Lange, S. Protein deimination and extracellular vesicle profiles in Antarctic seabirds. Biology. 2020, 9, 15. [CrossRef] [PubMed]

26. Vossenaar, E.R.; Zendman, A.J.; Van Venrooij, W.J.; Pruijn, G.J. PAD, a growing family of citrullinating enzymes: Genes, features and involvement in disease. Bioessays 2003, 25, 1106-1118. [CrossRef] [PubMed]

27. György, B.; Toth, E.; Tarcsa, E.; Falus, A.; Buzas, E.I. Citrullination: A posttranslational modification in health and disease. Int. J. Biochem. Cell Biol. 2006, 38, 1662-1677. [CrossRef] [PubMed]

28. Magnadottir, B.; Hayes, P.; Hristova, M.; Bragason, B.P.; Nicholas, A.P.; Dodds, A.W.; Gudmundsdottir, S.; Lange, S. Posttranslational Protein Deimination in Cod (Gadus morhua L.) Ontogeny-Novel Roles in Tissue Remodelling and Mucosal Immune Defences? Dev. Comp. Immunol. 2018, 87, 157-170. [CrossRef] [PubMed]

29. Magnadóttir, B.; Bragason, B.T.; Bricknell, I.R.; Bowden, T.; Nicholas, A.P.; Hristova, M.; Guðmundsdóttir, S.; Dodds, A.W.; Lange, S. Peptidylarginine deiminase and deiminated proteins are detected throughout early halibut ontogeny-Complement 
components C3 and C4 are post-translationally deiminated in halibut (Hippoglossus hippoglossus L.). Dev. Comp. Immunol. 2019, 92, 1-19. [CrossRef]

30. Alghamdi, M.; Alasmari, D.; Assiri, A.; Mattar, E.; Aljaddawi, A.A.; Alattas, S.G.; Redwan, E.M. An Overview of the Intrinsic Role of Citrullination in Autoimmune Disorders. J. Immunol. Res. 2019, 2019, 7592851. [CrossRef]

31. Bicker, K.L.; Thompson, P.R. The protein arginine deiminases: Structure, function, inhibition, and disease. Biopolymers 2013, 99, 155-163. [CrossRef]

32. Wang, S.; Wang, Y. Peptidylarginine deiminases in citrullination, gene regulation, health and pathogenesis. Biochim. Biophys. Acta 2013, 1829, 1126-1135. [CrossRef] [PubMed]

33. Witalison, E.E.; Thompson, P.R.; Hofseth, L.J. Protein Arginine Deiminases and Associated Citrullination: Physiological Functions and Diseases Associated with Dysregulation. Curr. Drug Targets 2015, 16, 700-710. [CrossRef] [PubMed]

34. Lange, S.; Gallagher, M.; Kholia, S.; Kosgodage, U.S.; Hristova, M.; Hardy, J.; Inal, J.M. Peptidylarginine Deiminases-Roles in Cancer and Neurodegeneration and Possible Avenues for Therapeutic Intervention via Modulation of Exosome and Microvesicle (EMV) Release? Int. J. Mol. Sci. 2017, 18, 1196. [CrossRef] [PubMed]

35. Mondal, S.; Thompson, P.R. Protein Arginine Deiminases (PADs): Biochemistry and Chemical Biology of Protein Citrullination. Acc. Chem Res. 2019, 52, 818-832. [CrossRef] [PubMed]

36. Jeffrey, C.J. Protein moonlighting: What is it, and why is it important? Philos. Trans. R Soc. Lond. B Biol. Sci. 2018, $373,20160523$. [CrossRef] [PubMed]

37. Rebl, A.; Köllner, B.; Anders, E.; Wimmers, K.; Goldammer, T. Peptidylarginine deiminase gene is differentially expressed in freshwater and brackish water rainbow trout. Mol. Biol Rep. 2010, 37, 2333-2339. [CrossRef]

38. Novák, L.; Zubáčová, Z.; Karnkowska, A.; Kolisko, M.; Hroudová, M.; Stairs, C.W.; Simpson, A.G.; Keeling, P.J.; Roger, A.J.; Čepička, I.; et al. Arginine deiminase pathway enzymes: Evolutionary history in metamonads and other eukaryotes. BMC Evol. Biol. 2016, 16, 197. [CrossRef]

39. Gavinho, B.; Sabatke, B.; Feijoli, V.; Rossi, I.V.; Da Silva, J.M.; Evans-Osses, I.; Palmisano, G.; Lange, S.; Ramirez, M.I. Peptidylarginine deiminase inhibition abolishes the production of large extracellular vesicles from Giardia intestinalis, affecting host-pathogen interactions by hindering adhesion to host cells. Front. Cell Infect. Microbiol. 2020, 10, 417. [CrossRef]

40. Bielecka, E.; Scavenius, C.; Kantyka, T.; Jusko, M.; Mizgalska, D.; Szmigielski, B.; Potempa, B.; Enghild, J.J.; Prossnitz, E.R.; Blom, A.M.; et al. Peptidyl arginine deiminase from Porphyromonas gingivalis abolishes anaphylatoxin C5a activity. J. Biol Chem. 2014, 289, 32481-32487. [CrossRef] [PubMed]

41. Kosgodage, U.S.; Matewele, P.; Mastroianni, G.; Kraev, I.; Brotherton, D.; Awamaria, B.; Nicholas, A.P.; Lange, S.; Inal, J.M. Peptidylarginine deiminase inhibitors reduce bacterial membrane vesicle release and sensitize bacteria to antibiotic treatment. Front. Cell Infect. Microbiol. 2019, 9, 227. [CrossRef] [PubMed]

42. El-Sayed, A.S.A.; Shindia, A.A.; AbouZaid, A.A.; Yassin, A.M.; Ali, G.S.; Sitohy, M.Z. Biochemical characterization of peptidylarginine deiminase-like orthologs from thermotolerant Emericella dentata and Aspergillus nidulans. Enzym. Microb. Technol. 2019, 124, 41-53. [CrossRef]

43. Lange, S.; Kraev, I.; Magnadóttir, B.; Dodds, A.W. Complement component C4-like protein in Atlantic cod (Gadus morhua L.) -Detection in ontogeny and identification of post-translational deimination in serum and extracellular vesicles. Dev. Comp. Immunol. 2019, 101, 103437. [CrossRef]

44. Magnadóttir, B.; Hayes, P.; Gísladóttir, B.; Bragason, B.P.; Hristova, M.; Nicholas, A.P.; Guðmundsdóttir, S.; Lange, S. Pentraxins CRP-I and CRP-II are post-translationally deiminated and differ in tissue specificity in cod (Gadus morhua L.) ontogeny. Dev. Comp. Immunol. 2018, 87, 1-11. [CrossRef] [PubMed]

45. Muraro, S.P.; De Souza, G.F.; Gallo, S.W.; Da Silva, B.K.; De Oliveira, S.D.; Vinolo, M.A.R.; Saraiva, E.M.; Porto, B.N. Respiratory Syncytial Virus induces the classical ROS-dependent NETosis through PAD-4 and necroptosis pathways activation. Sci Rep. 2018, 8, 14166. [CrossRef] [PubMed]

46. Casanova, V.; Sousa, F.H.; Shakamuri, P.; Svoboda, P.; Buch, C.; D’Acremont, M.; Christophorou, M.A.; Pohl, J.; Stevens, C.; Barlow, P.G. Citrullination Alters the Antiviral and Immunomodulatory Activities of the Human Cathelicidin LL-37 During Rhinovirus Infection. Front. Immunol. 2020, 11, 85. [CrossRef] [PubMed]

47. Kholia, S.; Jorfi, S.; Thompson, P.R.; Causey, C.P.; Nicholas, A.P.; Inal, J.; Lange, S. A Novel Role for Peptidylarginine Deiminases (PADs) in Microvesicle Release: A Therapeutic Potential for PAD Inhibitors to Sensitize Prostate Cancer Cells to Chemotherapy. J. Extracell. Vesicles 2015, 4, 26192. [CrossRef]

48. Kosgodage, U.S.; Trindade, R.P.; Thompson, P.R.; Inal, J.M.; Lange, S. Chloramidine/Bisindolylmaleimide -I-Mediated Inhibition of Exosome and Microvesicle Release and Enhanced Efficacy of Cancer Chemotherapy. Int. J. Mol. Sci. 2017, 18, 1007. [CrossRef]

49. Kosgodage, U.S.; Uysal-Onganer, P.; MacLatchy, A.; Kraev, I.; Chatterton, N.P.; Nicholas, A.P.; Inal, J.M.; Lange, S. Peptidylarginine Deiminases Post-Translationally Deiminate Prohibitin and Modulate Extracellular Vesicle Release and MicroRNAs in Glioblastoma Multiforme. Int. J. Mol. Sci. 2018, 20, 103. [CrossRef]

50. Uysal-Onganer, P.; MacLatchy, A.; Mahmoud, R.; Kraev, I.; Thompson, P.R.; Inal, J.M.; Lange, S. Peptidylarginine Deiminase Isozyme-Specific PAD2, PAD3 and PAD4 Inhibitors Differentially Modulate Extracellular Vesicle Signatures and Cell Invasion in Two Glioblastoma Multiforme Cell Lines. Int. J. Mol. Sci. 2020, 21, 1495. [CrossRef]

51. Inal, J.M.; Ansa-Addo, E.A.; Lange, S. Interplay of host-pathogen microvesicles and their role in infectious disease. Biochem. Soc. Trans. 2013, 41, 258-262. [CrossRef] [PubMed] 
52. Colombo, M.; Raposo, G.; Théry, C. Biogenesis, secretion, and intercellular interactions of exosomes and other extracellular vesicles. Annu. Rev. Cell Dev. Biol. 2014, 30, 255-289. [CrossRef] [PubMed]

53. Turchinovich, A.; Drapkina, O.; Tonevitsky, A. Transcriptome of extracellular vesicles: State-of-the-art. Front. Immunol. 2019, 10, 202. [CrossRef] [PubMed]

54. Vagner, T.; Chin, A.; Mariscal, J.; Bannykh, S.; Engman, D.M.; Di Vizio, D. Protein composition reflects extracellular vesicle heterogeneity. Proteomics 2019, 19, e1800167. [CrossRef] [PubMed]

55. Antwi-Baffour, S.; Malibha-Pinchbeck, M.; Stratton, D.; Jorfi, S.; Lange, S.; Inal, J. Plasma mEV levels in Ghanain malaria patients with low parasitaemia are higher than those of healthy controls, raising the potential for parasite markers in mEVs as diagnostic targets. J. Extracell. Vesicles 2019, 9, 1697124. [CrossRef]

56. Hessvik, N.P.; Llorente, A. Current knowledge on exosome biogenesis and release. Cell Mol. Life Sci. 2018, 75, 193-208. [CrossRef]

57. Ramirez, S.H.; Andrews, A.M.; Paul, D.; Pachter, J.S. Extracellular vesicles: Mediators and biomarkers of pathology along CNS barriers. Fluids Barriers CNS. 2018, 15, 19. [CrossRef]

58. Théry, C.; Witwer, K.W.; Aikawa, E.; Alcaraz, M.J.; Anderson, J.D.; Andriantsitohaina, R.; Antoniou, A.; Arab, T.; Archer, F.; Atkin-Smith, G.K.; et al. Minimal information for studies of extracellular vesicles 2018 (MISEV2018): A position statement of the International Society for Extracellular Vesicles and update of the MISEV2014 guidelines. J. Extracell. Vesicles. 2018, 7, 1535750. [CrossRef]

59. Nicholas, A.P.; Whitaker, J.N. Preparation of a monoclonal antibody to citrullinated epitopes: Its characterization and some applications to immunohistochemistry in human brain. Glia 2002, 37, 328-336. [CrossRef]

60. Lange, S.; Gögel, S.; Leung, K.Y.; Vernay, B.; Nicholas, A.P.; Causey, C.P.; Thompson, P.R.; Greene, N.D.; Ferretti, P. Protein deiminases: New players in the developmentally regulated loss of neural regenerative ability. Dev. Biol. 2011, 355, 205-214. [CrossRef]

61. Lange, S.; Rocha-Ferreira, E.; Thei, L.; Mawjee, P.; Bennett, K.; Thompson, P.R.; Subramanian, V.; Nicholas, A.P.; Peebles, D.; Hristova, M.; et al. Peptidylarginine deiminases: Novel drug targets for prevention of neuronal damage following hypoxic ischemic insult (HI) in neonates. J. Neurochem. 2014, 130, 555-562. [CrossRef]

62. Carroll, M.V.; Sim, R.B. Complement in health and disease. Adv. Drug Deliv. Rev. 2011, 63, 965-975. [CrossRef]

63. Lopez, B.I.; Santiago, K.G.; Lee, D.; Ha, S.; Seo, K. RNA Sequencing (RNA-Seq) Based Transcriptome Analysis in Immune Response of Holstein Cattle to Killed Vaccine against Bovine Viral Diarrhea Virus Type I. Animals 2020, 10, 344. [CrossRef] [PubMed]

64. Zhang, H.; Jiang, H.; Fan, Y.; Chen, Z.; Li, M.; Mao, Y.; Karrow, N.A.; Loor, J.J.; Moore, S.; Yang, Z. Transcriptomics and iTRAQ-Proteomics Analyses of Bovine Mammary Tissue with Streptococcus agalactiae-Induced Mastitis. J. Agric. Food Chem. 2018, 66, 11188-11196. [CrossRef] [PubMed]

65. Bao, Y.; Wang, L.; Shi, L.; Yun, F.; Liu, X.; Chen, Y.; Chen, C.; Ren, Y.; Jia, Y. Transcriptome profiling revealed multiple genes and ECM-receptor interaction pathways that may be associated with breast cancer. Cell Mol. Biol. Lett. 2019, 24, 38. [CrossRef] [PubMed]

66. Rothenberger, N.J.; Somasundaram, A.; Stabile, L.P. The Role of the Estrogen Pathway in the Tumor Microenvironment. Int. J. Mol. Sci. 2018, 19, 611. [CrossRef] [PubMed]

67. Sanajou, D.; Ghorbani Haghjo, A.; Argani, H.; Aslani, S. AGE-RAGE axis blockade in diabetic nephropathy: Current status and future directions. Eur. J. Pharmacol. 2018, 833, 158-164. [CrossRef] [PubMed]

68. Senatus, L.M.; Schmidt, A.M. The AGE-RAGE Axis: Implications for Age-Associated Arterial Diseases. Front. Genet. 2017, 8, 187. [CrossRef] [PubMed]

69. Ahmad, S.; Khan, H.; Siddiqui, Z.; Khan, M.Y.; Rehman, S.; Shahab, U.; Godovikova, T.; Silnikov, V.; Moinuddin. AGEs, RAGEs and s-RAGE; friend or foe for cancer. Semin. Cancer Biol. 2018, 49, 44-55. [CrossRef]

70. Vetuschi, A.; Pompili, S.; Di Marco, G.P.; Calvaruso, F.; Iacomino, E.; Angelosante, L.; Festuccia, C.; Colapietro, A.; Sferra, R. Can the AGE/RAGE/ERK signalling pathway and the epithelial-to-mesenchymal transition interact in the pathogenesis of chronic rhinosinusitis with nasal polyps? Eur. J. Histochem. 2020, 64, 3079.

71. Waghela, B.N.; Vaidya, F.U.; Ranjan, K.; Chhipa, A.S.; Tiwari, B.S.; Pathak, C. AGE-RAGE synergy influences programmed cell death signaling to promote cancer. Mol. Cell Biochem. 2021, 476, 585-598. [CrossRef]

72. Valkovic, A.L.; Bathgate, R.A.; Samuel, C.S.; Kocan, M. Understanding relaxin signalling at the cellular level. Mol. Cell Endocrinol. 2019, 487, 24-33. [CrossRef] [PubMed]

73. Wang, Y.J.; Xiao, J.X.; Li, S.; Liu, J.J.; Alugongo, G.M.; Cao, Z.J.; Yang, H.J.; Wang, S.X.; Swanson, K.C. Protein Metabolism and Signal Pathway Regulation in Rumen and Mammary Gland. Curr. Protein Pept. Sci. 2017, 18, 636-651. [CrossRef] [PubMed]

74. Mou, Y.; Wang, J.; Wu, J.; He, D.; Zhang, C.; Duan, C.; Li, B. Ferroptosis, a new form of cell death: Opportunities and challenges in cancer. J. Hematol. Oncol. 2019, 12, 34. [CrossRef]

75. Li, J.; Cao, F.; Yin, H.L.; Huang, Z.J.; Lin, Z.T.; Mao, N.; Sun, B.; Wang, G. Ferroptosis: Past, present and future. Cell Death Dis. 2020, 11, 88. [CrossRef]

76. Dwivedi, N.; Radic, M. Citrullination of autoantigens implicates NETosis in the induction of autoimmunity. Ann. Rheum. Dis. 2014, 73, 483-491. [CrossRef] [PubMed]

77. Van der Spek, A.H.; Fliers, E.; Boelen, A. The classic pathways of thyroid hormone metabolism. Mol. Cell Endocrinol. 2017, 458, 29-38. [CrossRef] 
78. Yau, W.W.; Yen, P.M. Thermogenesis in Adipose Tissue Activated by Thyroid Hormone. Int. J. Mol. Sci. 2020, 21, 3020. [CrossRef] [PubMed]

79. Zucchi, R.; Rutigliano, G.; Saponaro, F. Novel thyroid hormones. Endocrine 2019, 66, 95-104. [CrossRef] [PubMed]

80. Mullur, R.; Liu, Y.Y.; Brent, G.A. Thyroid hormone regulation of metabolism. Physiol. Rev. 2014, 94, 355-382. [CrossRef] [PubMed]

81. Morshed, S.A.; Ma, R.; Latif, R.; Davies, T.F. Cleavage Region Thyrotropin Receptor Antibodies Influence Thyroid Cell Survival In Vivo. Thyroid 2019, 29, 993-1002. [CrossRef]

82. Guo, W.; Zheng, Y.; Xu, B.; Ma, F.; Li, C.; Zhang, X.; Wang, Y.; Chang, X. Investigating the expression, effect and tumorigenic pathway of PADI2 in tumors. Oncol. Targets Ther. 2017, 10, 1475-1485. [CrossRef]

83. Kozlowski, H.N.; Lai, E.T.; Havugimana, P.C.; White, C.; Emili, A.; Sakac, D.; Binnington, B.; Neschadim, A.; McCarthy, S.D.; Branch, D.R. Extracellular histones identified in crocodile blood inhibit in-vitro HIV-1 infection. AIDS 2016, 30, $2043-2052$. [CrossRef] [PubMed]

84. Fuhrmann, J.; Thompson, P.R. Protein Arginine Methylation and Citrullination in Epigenetic Regulation. ACS Chem. Biol. 2016, 11, 654-668. [CrossRef] [PubMed]

85. Florin-Christensen, M.; Schnittger, L.; Dominguez, M.; Mesplet, M.; Rodríguez, A.; Ferreri, L.; Asenzo, G.; Wilkowsky, S.; Farber, M.; Echaide, I.; et al. Search for Babesia bovis vaccine candidates. Parassitologia 2007, 49 (Suppl. S1), 9-12. [PubMed]

86. Ragg, H. The role of serpins in the surveillance of the secretory pathway. Cell. Mol. Life Sci. 2007, 64, 2763-2770. [CrossRef] [PubMed]

87. Laporte, M.; Naesens, L. Airway proteases: An emerging drug target for influenza and other respiratory virus infections. Curr. Opin. Virol. 2017, 24, 16-24. [CrossRef] [PubMed]

88. Barksdale, S.M.; Hrifko, E.J.; Chung, E.M.; Van Hoek, M.L. Peptides from American alligator plasma are antimicrobial against multi-drug resistant bacterial pathogens including Acinetobacter baumannii. BMC Microbiol. 2016, 16, 189. [CrossRef] [PubMed]

89. Grenfell, B.T. Gastrointestinal nematode parasites and the stability and productivity of intensive ruminant grazing systems. Philos. Trans. R. Soc. Lond. B 1988, 312, 541-563.

90. Gudmundsdottir, B.; Skirnisson, K. The third newly discovered Eimeria species (Protozoa: Eimeriidae) described from wild reindeer, Rangifer tarandus, in Iceland. Parasitol. Res. 2006, 99, 659-662. [CrossRef]

91. Halvorsen, O. Epidemiology of reindeer parasites. Parasitol. Today 1986, 2, 334-339. [CrossRef]

92. Hoberg, E.P.; Kutz, S.J.; Galbreath, K.E.; Cook, J. Arctic biodiversity: From discovery to faunal baselines-Revealing the history of a dynamic ecosystem. J. Parasitol. 2003, 89, S84-S95.

93. Hrabok, J.T.; Oksanen, A.; Nieminen, M.; Rydzik, A.; Uggla, A.; Waller, P.J. Reindeer as hosts for nematode parasites of sheep and cattle. Vet. Parasitol. 2006, 136, 297-306. [CrossRef] [PubMed]

94. Josefsen, T.D.; Oksanen, A.; Gjerde, B. Parasites in reindeer in Fennoscandia-A Review. Norsk Veterinærtidskrift 2014, 2, $186-201$.

95. Skírnisson, K.; Cuyler, C. A new Eimeria species (Protozoa: Eimeriidae) from caribou in Ameralik, West Greenland. Para Res. 2016, 115, 1611-1615. [CrossRef]

96. Hamnes, I.S.; Gjerde, B.; Robertson, L.; Vikøren, T.; Handeland, K. Prevalence of Cryptosporidium and Giardia in free-ranging wild cervids in Norway. Vet. Parasitol. 2006, 141, 30-41. [CrossRef] [PubMed]

97. Stensvold, C.R.; Lebbad, M.; Clark, C.G. Genetic characterisation of uninucleated cyst-producing Entamoeba spp. from ruminants. Int. J. Parasitol. 2010, 40, 775-778. [CrossRef] [PubMed]

98. Dubey, J.P. Redescription of Besnoitia tarandi (Protozoa: Apicomplexa) from the reindeer (Rangifer tarandus). Int. J. Parasitol. 2004, 34, 1273-1287. [CrossRef] [PubMed]

99. Madubata, C.; Dunams-Morel, D.B.; Elkin, B.; Oksanen, A.; Rosenthal, B.M. Evidence for a recent population bottleneck in an Apicomplexan parasite of caribou and reindeer, Besnoitia tarandi. Infect. Genet. Evol. 2012, 12, 1605-1613. [CrossRef]

100. Oksanen, A.; Åsbakk, K.; Nieminen, M.; Norberg, H.; Näreaho, A. Antibodies against Toxoplasma gondii in Fennoscandian reindeer-Association with the degree of domestication. Parasitol. Int. 1997, 46, 255-261. [CrossRef]

101. Vikøren, T.; Tharaldsen, J.; Fredriksen, B.; Handeland, K. Prevalence of Toxoplasma gondii antibodies in wild red deer, roe deer, moose, and reindeer from Norway. Vet. Parasitol. 2004, 120, 159-169. [CrossRef]

102. Dubey, J.P.; Lewis, B.; Beam, K.; Abbitt, B. Transplacental toxoplasmosis in a reindeer (Rangifer tarandus) fetus. Vet. Parasitol 2002, 110, 131-135. [CrossRef]

103. Kutz, S.J.; Elkin, B.T.; Panayi, D.; Dubey, J.P. Prevalence of Toxoplasma gondii antibodies in barren-ground caribou (Rangifer tarandus groenlandicus) from the Canadian Arctic. J. Parasitol. 2001, 87, 439-442. [CrossRef]

104. Gjerde, B. Studies on the Sarcocyst Morphology and Life Cycle of Six Species of Sarcocystis from Reindeer (Rangifer tarandus tarandus). Ph.D. Thesis, Norges Veterinærhøgskole, Oslo, Norway, 1985.

105. Dahlgren, S.S.; Gjerde, B.; Skirnisson, K.; Gudmundsdottir, B. Morphological and molecular identification of three species of Sarcocystis in reindeer (Rangifer tarandus tarandus) in Iceland. Vet. Parasitol. 2007, 149, 191-198. [CrossRef] [PubMed]

106. Nikander, S.; Saari, S. Notable seasonal variation observed in the morphology of the reindeer rumen fluke (Paramphistomum leydeni) in Finland. Rangifer 2007, 27, 47-57. [CrossRef]

107. Tøllefsen, L. Endoparasitter hos Rein (Rangifer tarandus L.) med Særlig Vekt på Gastrointestinale Nematoda. Master's Thesis, University of Tromsø, Tromsø, Norway, 1983; 83p.

108. Bye, K. Cestodes of reindeer (Rangifer tarandus platyrhynchus Vrolik) on the Arctic islands of Svalbard. Can. J. Zool. 1985, 63, 2885-2887. [CrossRef] 
109. Dieterich, R.A. Current status of reindeer/caribou diseases in Alaska. In Proceedings of the 2nd International Reindeer/Caribou Symposium, Röros, Norway, 17-21 September 1979; Reimers, E., Gaare, E., Skjenneberg, S., Eds.; Direktoratet for vilt og Ferskvannsfisk: Trondheim, Norway, 1980; pp. 438-441.

110. Kummenje, K. Diseases in reindeer in northern Norway. In Proceedings of the 2nd International Reindeer/Caribou Symposium, Röros, Norway, 17-21 September 1979; Reimers, E., Gaare, E., Skjenneberg, S., Eds.; Direktoratet for vilt og Ferskvannsfisk: Trondheim, Norway, 1980; pp. 456-458.

111. Bye, K. Parasitter hos Svalbardrein Rangifer tarandus platyrhyncus. Fauna 1983, 36, 82-86.

112. Hoberg, E.P.; Kocan, A.A.; Rickard, L.G. Gastrointestinal strongyles in wild ruminants. In Parasitic Diseases of Wild Mammals, 2nd ed.; Samuel, W.M., Pybus, M.J., Kocan, A.A., Eds.; Manson Publishing Ltd.: London, UK, 2001; pp. $193-227$.

113. Fruetel, M.; Lankester, M.W. Gastrointestinal helminths of woodland and barren ground caribou (Rangifer tarandus) in Canada, with key to species. Can. J. Zool. 1989, 67, 2253-2269. [CrossRef]

114. Lichtenfels, J.R.; Hoberg, E.P. The systematics of nematodes that cause ostertagiasis in domestic and wild ruminants in North America: An update and a key to species. Vet. Parasitol. 1993, 46, 33-53. [CrossRef]

115. Stien, A.; Irvine, R.J.; Ropstads, E.; Halvorsen, O.; Langvatn, R.; Albon, S.D. The impact of gastro-intestinal nematodes on wild reindeer: Experimental and cross-sectional studies. J. Anim. Ecol. 2002, 71, 937-945. [CrossRef]

116. Bain, O.; Nikander, S. Un nématode ashasmidien dans les capillaires de l'oreille du renne, Lappnema auris. Ann. Parasitol. Hum. Comp. 1983, 58, 383-390. [CrossRef]

117. Rehbinder, C. Some vector borne parasites in Swedish reindeer (Rangifer tarandus tarandus L). Rangifer 1990, 2, 67-73. [CrossRef]

118. Nikander, S.; Laaksonen, S.; Saari, S. Oksanen, A. The morphology of the filaroid nematode Setaria tundra, the cause of peritonitis in reindeer Rangifer tarandus. J. Helminthol. 2007, 81, 49-55. [CrossRef] [PubMed]

119. Davidson, R.K.; Mørk, T.; Holmgren, K.E.; Oksanen, A. Infection with brainworm (Elaphostrongylus rangiferi) in reindeer (Rangifer tarandus ssp.) in Fennoscandia. Acta Vet. Scand. 2020, 62, 24. [CrossRef]

120. Kummeneje, K. Dictyocaulus viviparus infestation in reindeer in northern Norway-A contribution to its epidemiology. Acta Vet. Scand. 1977, 18, 86-90. [CrossRef] [PubMed]

121. Nikander, S.; Rahko, T. Studies on the occurence of lung worm infection in the reindeer in Finnish Eastern Lapland. Rangifer 1990, 4, 59. [CrossRef]

122. Haugerud, R.E.; Nilssen, A.C. Life history of the reindeer sinus worm, Linguatula arctica (Pentastomida), a prevalent parasite in reindeer calves. Rangifer 1990, 3, 333-334. [CrossRef]

123. Helle, T.; Tavainen, L. Effects of insect harrassment on weight gain and survival in reindeer calves. Rangifer 1984, 4, 24-27. [CrossRef]

124. Persen, E.; Jacobsen, E.; Lenvik, D.; Skjenneberg, S. Forsøk med behandling av reinkalver mot reinbremslarver (Oedomagena tarandi L og Cephenemyia trompe L). Effekt på kalvens kondisjon målt ved levende vekt og overlevinsevne. Rangifer 1982, 2, 39-49. [CrossRef]

125. Rehbinder, C.; Nikander, S. Ren Och Rensjukdomar; Studentlitteratur: Lund, Norway, 1999; pp. $13-132$.

126. Liu, W.; Nie, C.; Zhang, L.; Wang, R.; Liu, A.; Zhao, W.; Li, H. First detection and genotyping of Enterocytozoon bieneusi in reindeers (Rangifer tarandus): A zoonotic potential of ITS genotypes. Parasit. Vectors 2015, 8, 526. [CrossRef]

127. Evans, A.L.; Das Neves, C.G.; Finstad, G.F.; Beckmen, K.B.; Skjerve, E.; Nymo, I.H.; Tryland, M. Evidence of alphaherpesvirus infections in Alaskan caribou and reindeer. BMC Vet. Res. 2012, 8, 5. [CrossRef]

128. Das Neves, C.G.; Ihlebæk, H.M.; Skjerve, E.; Hemmingsen, W.; Li, H.; Tryland, M. Gammaherpesvirus infection in semidomesticated reindeer (Rangifer tarandus tarandus): A cross-sectional, serologic study in northern Norway. J. Wildl. Dis. 2013, 49, 261-269. [CrossRef] [PubMed]

129. Das Neves, C.G.; Roth, S.; Rimstad, E.; Thiry, E.; Tryland, M. Cervid herpesvirus 2 infection in reindeer: A review. Vet. Microbiol. 2010, 143, 70-80. [CrossRef]

130. Paulsen, K.M.; Das Neves, C.G.; Granquist, E.G.; Madslien, K.; Stuen, S.; Pedersen, B.N.; Vikse, R.; Rocchi, M.; Laming, E.; Stiasny, K.; et al. Cervids as sentinel-species for tick-borne encephalitis virus in Norway-A serological study. Zoonoses Public Health 2020, 67, 342-351. [CrossRef] [PubMed]

131. Schürch, A.C.; Schipper, D.; Bijl, M.A.; Dau, J.; Beckmen, K.B.; Schapendonk, C.M.; Raj, V.S.; Osterhaus, A.D.; Haagmans, B.L.; Tryland, M.; et al. Metagenomic survey for viruses in Western Arctic caribou, Alaska, through iterative assembly of taxonomic units. PLoS ONE 2014, 20, e105227. [CrossRef] [PubMed]

132. Klein, J.; Tryland, M. Characterisation of parapoxviruses isolated from Norwegian semi-domesticated reindeer (Rangifer tarandus tarandus). Virol. J. 2005, 2, 79. [CrossRef] [PubMed]

133. Oreshkova, N.; Molenaar, R.J.; Vreman, S.; Harders, F.; Oude Munnink, B.B.; Hakze-van der Honing, R.W.; Gerhards, N.; Tolsma, P.; Bouwstra, R.; Sikkema, R.S.; et al. SARS-CoV-2 infection in farmed minks, the Netherlands, April and May 2020. Euro Surveill. 2020, 25, 2001005. [CrossRef] [PubMed]

134. Oude Munnink, B.B.; Sikkema, R.S.; Nieuwenhuijse, D.F.; Molenaar, R.J.; Munger, E.; Molenkamp, R.; Van der Spek, A.; Tolsma, P.; Rietveld, A.; Brouwer, M.; et al. Transmission of SARS-CoV-2 on mink farms between humans and mink and back to humans. Science 2021, 371, 172-177. [CrossRef] [PubMed] 
135. Hammer, A.S.; Quaade, M.L.; Rasmussen, T.B.; Fonager, J.; Rasmussen, M.; Mundbjerg, K.; Lohse, L.; Strandbygaard, B.; Jørgensen, C.S.; Alfaro-Núñez, A.; et al. SARS-CoV-2 Transmission between Mink (Neovison vison) and Humans, Denmark. Emerg. Infect. Dis. 2021, 27, 547-551. [CrossRef]

136. Waters, W.R.; Palmer, M.V.; Bannantine, J.P.; Greenwald, R.; Esfandiari, J.; Andersen, P.; McNair, J.; Pollock, J.M.; Lyashchenko, K.P. Antibody responses in reindeer (Rangifer tarandus) infected with Mycobacterium bovis. Clin. Diagn. Lab. Immunol. 2005, 12, 727-735. [CrossRef]

137. Rovani/, E.R.; Beckmen/, K.B.; Highland/, M.A. Mycoplasma ovipneumoniae Associated with Polymicrobial Pneumonia in a Free-Ranging Yearling Barren Ground Caribou (Rangifer tarandus granti) from Alaska, USA. J. Wildl. Dis. 2019, 55, 733-736. [CrossRef] [PubMed]

138. Abdussalam, M.; Fein, D.A. Brucellosis as a world problem. Dev. Biol. Stand. 1976, 31, 9-23. [PubMed]

139. Godfroid, J.; Garin-Bastuji, B.; Saegerman, C.; Blasco, J.M. Brucellosis in terrestrial wildlife. Rev. Sci. Technol. 2013, 32, $27-42$. [CrossRef] [PubMed]

140. Stella, E.; Mari, L.; Gabrieli, J.; Barbante, C.; Bertuzzo, E. Permafrost dynamics and the risk of anthrax transmission: A modelling study. Sci. Rep. 2020, 10, 16460. [CrossRef]

141. Aschfalk, A.; Valentin-Weigand, P.; Müller, W.; Goethe, R. Toxin types of Clostridium perfringens isolated from free-ranging, semi-domesticated reindeer in Norway. Vet. Rec. 2002, 151, 210-213. [CrossRef] [PubMed]

142. Kummeneje, K.; Bakken, G. Clostridium perfringens enterotoxaemia in reindeer. Nord. Vet. Med. 1973, 25, $196-202$.

143. Embury-Hyatt, C.K.; Wobeser, G.; Simko, E.; Woodbury, M.R. Investigation of a syndrome of sudden death, splenomegaly, and small intestinal hemorrhage in farmed deer. Can. Vet. J. 2005, 46, 702-708.

144. Sundset, M.A.; Kohn, A.; Mathiesen, S.D.; Praesteng, K.E. Eubacterium rangiferina, a novel usnic acid-resistant bacterium from the reindeer rumen. Naturwissenschaften 2008, 95, 741-749. [CrossRef]

145. Bondo, K.J.; Macbeth, B.; Schwantje, H.; Orsel, K.; Culling, D.; Culling, B.; Tryland, M.; Nymo, I.H.; Kutz, S. Health Survey of Boreal Caribou (Rangifer tarandus caribou) in Northeastern British Columbia, Canada. J. Wildl. Dis. 2019, 55, 544-562. [CrossRef]

146. Requena, J.R.; Wille, H. The Structure of the Infectious Prion Protein and Its Propagation. Prog. Mol. Biol. Transl. Sci. 2017, 150, 341-359.

147. Osterholm, M.T.; Anderson, C.J.; Zabel, M.D.; Scheftel, J.M.; Moore, K.A.; Appleby, B.S. Chronic Wasting Disease in Cervids: Implications for Prion Transmission to Humans and Other Animal Species. mBio 2019, 10, e01091-19. [CrossRef]

148. Sakudo, A. Chronic Wasting Disease: Current Assessment of Transmissibility. Curr. Issues Mol. Biol. 2020, 36, 13-22. [CrossRef]

149. Safar, J.G.; Lessard, P.; Tamgüney, G.; Freyman, Y.; Deering, C.; Letessier, F.; Dearmond, S.J.; Prusiner, S.B. Transmission and detection of prions in feces. J. Infect. Dis. 2008, 198, 81-89. [CrossRef] [PubMed]

150. Trone-Launer, E.K.; Wang, J.; Lu, G.; Mateus-Pinilla, N.E.; Zick, P.R.; Lamer, J.T.; Shelton, P.A.; Jacques, C.N. Differential gene expression in chronic wasting disease-positive white-tailed deer (Odocoileus virginianus). Ecol. Evol. 2019, 9, 12600-12612. [CrossRef]

151. Jang, B.; Kim, E.; Choi, J.K.; Jin, J.K.; Kim, J.I.; Ishigami, A.; Maruyama, N.; Carp, R.I.; Kim, Y.S.; Choi, E.K. Accumulation of citrullinated proteins by up-regulated peptidylarginine deiminase 2 in brains of scrapie-infected mice: A possible role in pathogenesis. Am. J. Pathol. 2008, 173, 1129-1142. [CrossRef] [PubMed]

152. Young, D.S.; Meersman, F.; Oxley, D.; Webster, J.; Gill, A.C.; Bronstein, I.; Lowe, C.R.; Dear, D.V. Effect of enzymatic deimination on the conformation of recombinant prion protein. Biochim. Acta Biophys. 2009, 1794, 1123-1133. [CrossRef] [PubMed]

153. Jang, B.; Ishigami, A.; Maruyama, N.; Carp, R.I.; Kim, Y.S.; Choi, E.K. Peptidylarginine deiminase and protein citrullination in prion diseases: Strong evidence of neurodegeneration. Prion 2013, 7, 42-46. [CrossRef] [PubMed]

154. Jang, B.; Jin, J.K.; Jeon, Y.C.; Cho, H.J.; Ishigami, A.; Choi, K.C.; Carp, R.I.; Maruyama, N.; Kim, Y.S.; Choi, E.K. Involvement of peptidylarginine deiminase-mediated post-translational citrullination in pathogenesis of sporadic Creutzfeldt-Jakob disease. Acta Neuropathol. 2010, 119, 199-210. [CrossRef]

155. Jang, B.; Jeon, Y.C.; Shin, H.Y.; Lee, Y.J.; Kim, H.; Kondo, Y.; Ishigami, A.; Kim, Y.S.; Choi, E.K. Myelin Basic Protein Citrullination, a Hallmark of Central Nervous System Demyelination, Assessed by Novel Monoclonal Antibodies in Prion Diseases. Mol. Neurobiol. 2018, 55, 3172-3184. [CrossRef]

156. Sancandi, M.; Uysal-Onganer, P.; Kraev, I.; Mercer, A.; Lange, S. Protein Deimination Signatures in Plasma and Plasma-EVs and Protein Deimination in the Brain Vasculature in a Rat Model of Pre-Motor Parkinson's Disease. Int. J. Mol. Sci. 2020, $21,2743$. [CrossRef]

157. Basu, U.; Almeida, L.M.; Dudas, S.; Graham, C.E.; Czub, S.; Moore, S.S.; Guan, L.L. Gene expression alterations in Rocky Mountain elk infected with chronic wasting disease. Prion 2012, 6, 282-301. [CrossRef] [PubMed]

158. Moore, S.J.; West Greenlee, M.H.; Kondru, N.; Manne, S.; Smith, J.D.; Kunkle, R.A.; Kanthasamy, A.; Greenlee, J.J. Experimental Transmission of the Chronic Wasting Disease Agent to Swine after Oral or Intracranial Inoculation. J. Virol. 2017, 91, e00926-17. [CrossRef] [PubMed]

159. Waddell, L.; Greig, J.; Mascarenhas, M.; Otten, A.; Corrin, T.; Hierlihy, K. Current evidence on the transmissibility of chronic wasting disease prions to humans-A systematic review. Transbound. Emerg. Dis. 2018, 65, 37-49. [CrossRef]

160. Benestad, S.L.; Telling, G.C. Chronic wasting disease: An evolving prion disease of cervids. Handb. Clin. Neurol. 2018, 153, 135-151. [PubMed] 